\title{
LAS INJUSTICIAS DE LA JUSTICIA: UN ANÁLISIS DE PRECEDENTES JUDICIALES SOBRE PROTECCIÓN A LA POBLACIÓN CARCELARIA EN COLOMBIA A PARTIR DE LA DIGNIDAD HUMANA*
}

\author{
THE UNJUST OF THE JUSTICE, A \\ STUDY OF STARE DECISIS ABOUT \\ PROTECTION OF THE JAIL POPULATION \\ IN COLOMBIA SINCE HUMAN DIGNITY
}

\author{
Viridiana Molinares-Hassan** \\ Adel Tolosa-Morales*** \\ Margarita Quintero-Ochoa ${ }^{* * * *}$
}

Fecha de recepción: 11 de agosto de 2015 Fecha de aceptación: 2 de marzo de 2016 Disponible en línea: 30 de mayo de 2016

\section{Para citar este artículo/To cite this article}

\begin{abstract}
Molinares-Hassan, Viridiana; Tolosa-Morales, Adel \& Quintero-Ochoa, Margarita, Las injusticias de la Justicia: un análisis de precedentes judiciales sobre protección a la población carcelaria en Colombia a partir de la dignidad humana, 132 Vniversitas, 235-310 (2016). http://dx.doi. org/10.11144/Javeriana.vj132.ijap

doi:10.11144/Javeriana.vj132.ijap
\end{abstract}

* Artículo de investigación. Se reconoce la participación como asistente de investigación de Alfredo Bula-Beleño, abogado de la Universidad del Norte, a quien le agradecemos su compromiso y dedicación, además de su pasión en un complejo tema que nos une y ante una situación injusta.

** Doctora en derecho público y filosofía jurídico política, Universidad Autónoma de Barcelona, UAB, España. Máster en Literatura comparada y estudios culturales, Universidad Autónoma de Barcelona, UAB, España. Magíster en desarrollo social, Universidad del Norte, Barranquilla, Colombia. Diplomada en derechos humanos y derecho internacional humanitario, American University, Washington, D.C. Profesora investigadora, miembro de los grupos de investigación en Derecho y Ciencia Política, y Sociología del Derecho, Universidad del Norte y del grupo de Investigación en Libertad y seguridad: transformaciones del Estado, Universidad Autónoma de Barcelona. Contacto: vmolinar@uninorte.edu.co

*** Egresado del programa de Derecho, Universidad del Norte, Barranquilla, Colombia. Contacto: adelt@uninorte.edu.co

****A Abogada del programa de Derecho, Universidad del Norte, Barranquilla, Colombia. Contacto: mrquintero@uninorte.edu.co 


\section{RESUMEN}

El presente artículo presenta los resultados de una investigación cuyo objetivo fue determinar y analizar los casos de tutelas presentadas por la población carcelaria sobre las transgresiones de sus derechos, en el marco del Estado Constitucional, a partir del desconocimiento de la dignidad humana. En una primera parte, realizamos un breve estudio sobre el concepto de dignidad, para pasar a describir la situación del sistema penitenciario en Colombia, ante el cual se presentan las solicitudes de protección que analizamos desde las decisiones judiciales adoptadas por la Corte Constitucional colombiana (1992-2012). Luego de este análisis, nuestras conclusiones dan cuenta de que la jurisprudencia constitucional ha desarrollado un proceso argumentativo sólido, sobre la necesidad de protección a esta población vulnerable, pero hasta la fecha no ha sido posible la materialización de estos mandatos judiciales.

Palabras clave: jurisprudencia constitucional; dignidad humana; población carcelaria; juez constitucional 


\section{ABSTRACT}

This paper presents the results of an investigation which objective was to determinate and analyze the cases of the legal action taken for protecting the rights of the prison population, about transgressions of their rights, based on the ignorance of the human dignity. At first, we expose a short research about the concept of dignity. Straightaway we are going to describe the present situation of the Colombian penitentiary system, present situation that implies the presentation of protection solicitudes that we analyze from the judicial decisions adopted by the Constitutional Court of Colombia (1992-2012). After the analysis, we present our conclusions that show that the constitutional jurisprudence has developed a solid argumentative process, but until the date, it has not been possible to materialize the judicial mandates.

Keywords: Constitutional Jurisprudence; Human Dignity; Prison Population; Constitutional Judge

\section{SUMARIO}

Introducción.- I. Dignidad, un valor en construcción.- II. CárceLeS en Colombia: escenarios de DEgRAdación.- III. JuRisprudencia y DERECHOS.- IV. LOS CENTROS DE RECLUSIÓN.- V. LOS DERECHOS VIOLADOS. Conclusiones.- Bibliografía. 


\section{INTRODUCCIÓN}

Dentro de la línea de investigación Derechos y Justicia constitucional del Grupo de Investigación en Derecho y Ciencia Política de la Universidad del Norte (GIDEPI), hemos venido adelantando y dirigiendo una serie de investigaciones orientadas a determinar el alcance de la protección judicial a derechos constitucionales en sede de la Corte Constitucional de Colombia (en adelante, Corte). Esto bajo la premisa de que el Estado Constitucional es un modelo basado en el protagonismo del juez, que da cuenta del garantismo secundario propuesto por Luigi Ferrajoli', en razón a que la población - ante la falta de garantías primarias que el legislador y el ejecutivo deberían desarrollar - cuando está en estado de indefensión y vulneración, recurre al juez constitucional para la protección judicial de sus derechos.

En 2011, Viridiana Molinares-Hassan y Silvana InsignaresCERA adelantaron una investigación sobre la incorporación de la jurisprudencia del Tribunal Europeo de Derechos Humanos por parte de la Corte, en la que, como categorías para el análisis, establecieron la revisión de fallos de tutelas sobre población carcelaria; y analizaron el alcance de la dignidad humana como valor fundamental del Estado Constitucional. Junto a lo anterior, se propusieron determinar casos en los que la Corte utilizó jurisprudencia del Tribunal Europeo de Derechos Humanos para ampliar su narrativa sobre la dignidad humana. Con esto, pusieron en evidencia la forma como los tribunales constitucionales vienen haciendo uso de las fuentes formales de derecho a las que tienen que recurrir de manera obligatoria; pero, también, evidenciaron el recurso a otros instrumentos jurídicos, como la jurisprudencia del Tribunal Europeo, que conllevan una ampliación del alcance de principios constitucionales. En esta investigación, concluyeron que:

La Corte ha manifestado que la jurisprudencia internacional permite entender con claridad lo establecido por los tratados internacionales y le permite dar un mejor alcance a los derechos consagrados a nivel constitucional ${ }^{2}$.

1 Luigi Ferrajoli, Democracia y garantismo (Trotta, Madrid, 2008).

2 Silvana Insignares \& Viridiana Molinares, La dignidad humana: incorporación de la juris- 
De otra parte, también concluyeron:

En el caso de las sentencias analizadas [T-1030/03, T-684/05, T-1084/05, T-488/07] resulta evidente que el principio de la dignidad humana es la vía efectiva para la protección de los derechos de la población carcelaria, frente a la vulneración por parte de las autoridades del Estado que hacen igualmente evidente cómo desde estas pareciera que la privación de la libertad acarreara la privación de otros derechos que pudieron protegerse a partir de la dignidad por ser precisamente esta: principio, fundamento del Estado Social de Derecho $y$, fuente del ordenamiento jurídico ${ }^{3}$.

Con base en las conclusiones anteriores, Viridiana MolinaresHassan y los estudiantes de pregrado en derecho de la Universidad del Norte Adel Tolosa-Morales y Margarita Quintero-OchoA iniciaron un proceso de investigación, en el que se propusieron, como objetivo general, determinar y analizar los casos de tutelas presentadas por la población carcelaria, en los que se violaron derechos de esta población y en los que, precisamente, se configuraron estas violaciones, a partir del desconocimiento de la dignidad humana. A continuación, se presentan algunos resultados de esta fase de la investigación, en relación con la revisión de estos casos de tutela.

El presente artículo se compone de tres secciones. En Dignidad, un valor en construcción se contextualiza doctrinalmente el concepto de dignidad. Luego en Cárceles en Colombia: escenarios de degradación, damos cuenta de la problemática del sistema penitenciario nacional. En tercer lugar, en Jurisprudencia y derechos analizamos la jurisprudencia constitucional (1992-2012) ${ }^{4}$ —utilizamos como categorías para el análisis las zonas con mayores solicitudes de protección y los tipos de violaciones alegadas-. Finalmente, se presentan las conclusiones.

prudencia del Tribunal Europeo de Derechos Humanos por la Corte Constitucional Colombiana, 36 Revista de Derecho de la Universidad del Norte, 184-221, 218 (2011). Disponible en: http:/l rcientificas.uninorte.edu.co/index.php/derecho/article/view/1900/2221

3 Silvana Insignares \& Viridiana Molinares, La dignidad humana: incorporación de la jurisprudencia del Tribunal Europeo de Derechos Humanos por la Corte Constitucional Colombiana, 36 Revista de Derecho de la Universidad del Norte, 184-221, 218 (2011). Disponible en: http:// rcientificas.uninorte.edu.co/index.php/derecho/article/view/1900/2221

4 Consideramos que la sentencia con mayor relevancia es la tutela T-388-13 que, a nuestra consideración, amerita un estudio específico. 
En razón de lo anterior, la investigación da cuenta de un proceso que se desarrolla articulando las figuras del juez constitucional y los precedentes constitucionales por él desarrollados, sobre protección a la población carcelaria desde la dignidad humana.

Sin embargo, lo anterior no indica que la intervención judicial haya sido una vía eficaz para la solución sustancial de la problemática ya que, como analizamos en un estudio sobre el Activismo Judicial Dialógico de la Corte ${ }^{5}$, atendiendo al caso de la población carcelaria se encontraron dos sentencias significativas (T-153-98 y T-388-13), expedidas con quince años de diferencia entre una y otra y con los mismos objetivos, en razón a que ambas intentan superar, sin lograrlo, el estado de cosas inconstitucional en el que está esta población.

Lo anterior evidencia que, aunque en el país contemos con desarrollos legislativos y abundantes precedentes constitucionales dirigidos a la protección de la población carcelaria, esta sigue siendo objeto de violaciones. Esto se puede deducir de la muerte de 17 reclusos de la cárcel Modelo de Barranquilla (27 de enero de 2014), provocada por un incendio y alentada por la negativa de los guardianes a abrir las celdas, lo que provocó que los internos murieran asfixiados o incinerados ${ }^{6}$.

\section{DIGNIDAD, UN VALOR EN CONSTRUCCIÓN}

La dignidad del hombre ha sido definida, desde la ética kantiana, como el valor intrínseco que posee cada persona por el hecho de ser persona y desde el paradigma jurídico, se ha desarrollado a partir de la afirmación de la persona humana como un fin para el Estado.

Sin embargo, al rastrear los orígenes del concepto, antes de irrumpir en conceptualizaciones de la doctrina jurídica y la jurisprudencia, se registra una breve reseña que Giorgio AgAmben presenta sobre la dignidad en su obra Lo que queda de Auschwitz. El archivo y el testigo. Homo sacer III, que da cuenta de la génesis

5 Viridiana Molinares, Control judicial de constitucionalidad: de la crítica sobre su legitimidad democrática a la construcción de nuevas formas de democracia deliberativa, en Debates contemporáneos sobre el derecho público en Colombia, 84-110 (Uninorte, Barranquilla, 2015).

6 Daniel Escorcia, Van 17 internos muertos por incendio en cárcel de Barranquilla, El Tiempo (5 de febrero de 2014). Disponible en: http://www.eltiempo.com/archivo/documento/CMS13454358 
de la dignidad, atribuida primero a la imagen de la persona, para mostrar luego una mutación hacia la esfera de lo público con la ostentación de un cargo de poder político y, finalmente, remitir a su desdibujamiento con el totalitarismo nazi, que es precisamente uno de los eventos que plantea su reconceptualización en lo jurídico y hace de la dignidad humana el fundamento de los actuales Estados constitucionales.

Según Agamben, no sorprende que la dignidad tenga un origen jurídico, debido a que remite a la esfera del derecho público romano. Así, en principio, la dignidad hacía referencia a la investidura de quienes ostentaban cargos públicos e, incluso, tenía qué ver con los atuendos que lucían cuando se presentaban en público. Agamben afirma que, desde la época republicana, el término latino dignitas indicaba el rango y la autoridad que correspondía a los cargos públicos y, por extensión, a los cargos mismos. En este orden de ideas, explica cómo en la lectura del libro XII del Codex Iustitianus, que lleva por título De Dignitatibus, se velaba para que:

(...) el orden de las diversas 'dignidades' (no solo el de las tradicionales, de los senadores y cónsules, sino también las del prefecto del pretorio, del prepósito del sacro cubiculo, de los guardianes de las arcas públicas, de los decanos, de los epideméticos, de los metates y de los demás grados de burocracia bizantina) sea respetado hasta en los mínimos detalles, y contiene disposiciones para que el acceso a los cargos (la porta dignitatis) sea vedado a aquellos cuya vida no esté acorde con el rango que reviste (cuando, por ejemplo, hayan sido objeto de una nota de censura o de infamia) ${ }^{7}$.

Luego, Agamben explica que la construcción de una auténtica teoría de la dignidad es obra de los juristas y de los anonimistas medievales, para lo cual afirma:

[Ernst H.] Kantorowitz ha mostrado en un libro ya clásico que la ciencia jurídica se entrelaza aqui frecuentemente con la teología para establecer uno de los pilares de la teoría de la soberanía: el del carácter perpetuo del orden político. La dignidad se emancipa de su portador y se convierte en una persona ficticia, una especie de cuerpo místico que se añade al cuerpo real del magistrado o del emperador, de la misma forma que en Cristo la persona divina duplica su cuerpo humano. Esta emancipación culmina en el principio, repetido en innumerables

7 Giorgio Agamben, Lo que queda de Auschwitz. El archivo y el testigo. Homo Sacer III, 68 (PreTextos, Valencia, 2009). 
ocasiones por los juristas medievales, según el cual 'la dignidad nunca muere' (dignitas non moritur, Le roi ne meurt jamais) $^{8}$.

Con estas reseñas, Agamben explica las transformaciones de la dignidad en épocas más recientes:

Digna es ahora la persona que, a pesar de carecer de una dignidad pública, se conduce en todo y por todo como si la tuviera. Es algo que se manifiesta con claridad en relación con las clases que, después de la caída del Ancien régime, habian perdido hasta las últimas prerrogativas públicas que la monarquía absoluta les había dejado. Y, más tarde en las clases humildes, excluidas por definición de cualquier dignidad pública, a las que los educadores de toda lata empiezan a impartir lecciones de dignidad y honestidad de los pobres 9 .

Finalmente, Agamben cuestiona la ética de la dignidad ${ }^{10}$ en los eventos surgidos en el marco del nacionalsocialismo alemán, que dan cuenta de la negación de la dignidad a los prisioneros de los campos, y del resurgimiento de la dignidad como sustento de las nuevas constituciones de la Europa de posguerra.

Así, Agamben señala que:

Auschwitz marca el final y la ruina de toda ética de la dignidad y de la adecuación a una norma. La nuda vida, a la que el hombre ha sido reducido, [en los campos de concentración y exterminio] no exige nada ni se adecúa a nada: es ella misma la única norma, es absolutamente inmanente. Y el sentimiento último de pertenencia a la especie no puede ser en ningún caso una dignidad"I.

Y, precisamente, por la ruina de la dignidad, bajo el totalitarismo nazi, se entiende que la dignidad sea un concepto asimilado como un valor jurídico, a partir de la superación de la Segunda Guerra Mundial, como da cuenta la consagración en la Declaración Universal de los Derechos Humanos de 1948, cuyo Preámbulo establece: "el reconocimiento de la dignidad intrínseca de todos los hombres

8 Giorgio Agamben, Lo que queda de Auschwitz. El archivo y el testigo. Homo Sacer III, 67-68 (Pre-Textos, Valencia, 2009). Ernst H. Kantorowitz, Los dos cuerpos del rey: un estudio de teología política medieval (Akal, Madrid, 2012).

9 Giorgio Agamben, Lo que queda de Auschwitz. El archivo y el testigo. Homo Sacer III, 69 (PreTextos, Valencia, 2009).

10 Viridiana Molinares, La zona gris, imposibilidad de juicios y una nueva ética (Ediciones Uninorte, Barranquilla, 2012).

11 Giongio Agamben, Lo que queda de Auschwitz. El archivo y el testigo. Homo Sacer III, 71 (PreTextos, Valencia, 2009). 
es la base de la libertad, la justicia y la paz" y se refuerza en su artículo 1 que señala "todos los hombres nacen libres e iguales en dignidad y derechos"12. De igual forma, resulta relevante observarla en los países que perdieron la guerra, como en el artículo 1 de la Ley Fundamental de Alemania de 1949: "La dignidad del hombre es sagrada y constituye deber de todas las autoridades del Estado su respeto y protección"13 $\mathrm{y}$, en el artículo 3 de la Constitución Italiana de 1948, que se refiere a la dignidad social ${ }^{14}$.

Así, desde mediados del siglo XX, la doctrina jurídica inicia un importante proceso de reconceptualización y apropiación de la dignidad humana como soporte del nuevo constitucionalismo. Por ello, para el rastreo de las mutaciones sobre la dignidad humana, hasta llegar a su contenido jurídico actual, conviene citar el estudio de LuIs ROBERTO BARROSO ${ }^{15}$ sobre la dignidad, que involucra análisis de textos constitucionales y de jurisprudencia mundial.

El estudio de Barroso analiza una serie de casos sobre reproducción asistida, derecho a la vivienda, integridad personal, aborto, eutanasia, relaciones entre personas del mismo sexo, que ponen de presente que, aunque la dignidad tiene un origen tardío en el discurso jurídico, es hoy su mayor fundamento, al margen de que siga siendo un concepto en disputa e instrumentalizado.

En este orden de ideas, el autor brasileño cita las consagraciones constitucionales internas, del derecho internacional y de los desarrollos jurisprudenciales de diferentes países, para tratar de presentar los debates en torno al concepto de dignidad. Una conclusión relevante para este estudio es el análisis de BARROSO sobre la posibilidad de asumir la dignidad como valor, principio constitucional o como derecho fundamental.

12 Organización de las Naciones Unidas, ONU, Declaración Universal de los Derechos Humanos, Asamblea General, resolución 217 A (III), París, 10 de diciembre de 1948. Disponible en: http://www.un.org/es/documents/udhr/

13 República Federal de Alemania, Ley Fundamental de la República Federal de Alemania, 23 de mayo de 1949. Disponible en: http://ocw.um.es/cc.-juridicas/derecho-internacional-publico-1/ ejercicios-proyectos-y-casos-1/capitulo4/documento-20-constitucion-de-alemania.pdf, http:// www.wipo.int/wipolex/es/details.jsp?id=9482

14 República Italiana, Constitución, 1 de enero de 1948. Disponible en: http://www.ces.es/TRES MED/docum/ita-cttn-esp.pdf, http://www.quirinale.it/qrnw/statico/costituzione/costituzione. htm

15 Luis Roberto Barroso, La dignidad de la persona humana en el derecho constitucional contemporáneo. La construcción de un concepto jurídico a la luz de la jurisprudencia mundial (SIMONE Nevares, trad., Universidad del Externado, Bogotá, 2014). 
En su aspecto sustancial, la dignidad tiene qué ver con el valor intrínseco de cada individuo y su posición especial en el universo ${ }^{16}$, con su capacidad individual de tener acceso a la razón, de hacer escogencias morales y determinar su propio destino ${ }^{17}$.

Como valor, la dignidad tiene qué ver con una doble dimensión: "una interna, expresada en el valor intrínseco o propio de cada individuo; otra externa, que representa sus derechos, aspiraciones y responsabilidades, así como los correlativos deberes de terceros"18. En la dimensión externa, el autor admite limitaciones a la dignidad, como las que se le imponen a la población carcelaria en su libertad de locomoción. Sostiene, además, que "como valor la dignidad funciona como justificación moral y fundamento jurídico normativo de los derechos fundamentales"19 (cursivas fuera del texto).

De otra parte, BARroso se remite a RoBert Alexy para contextualizar la teoría de los principios y concluye que el papel fundamental de la dignidad humana como principio es funcionar como una fuente de derechos; $y$, por consiguiente, de deberes, incluyendo los derechos no expresamente enumerados, que son reconocidos como parte de las sociedades maduras ${ }^{20}$. Señala específicamente que: "En los casos que involucran lagunas en el ordenamiento jurídico, ambigüedades en el derecho, colisiones entre derechos fundamentales y tensiones entre derechos y metas colectivas, la dignidad humana puede ser una buena brújula en la búsqueda de la mejor solución"21.

16 Luis Roberto Barroso, La dignidad de la persona humana en el derecho constitucional contemporáneo. La construcción de un concepto jurídico a la luz de la jurisprudencia mundial, 19 (Simone Nevares, trad., Universidad del Externado, Bogotá, 2014).

17 Luis Roberto Barroso, La dignidad de la persona humana en el derecho constitucional contemporáneo. La construcción de un concepto jurídico a la luz de la jurisprudencia mundial, 109 (Simone Nevares, trad., Universidad del Externado, Bogotá, 2014).

18 Luis Roberto Barroso, La dignidad de la persona humana en el derecho constitucional contemporáneo. La construcción de un concepto jurídico a la luz de la jurisprudencia mundial, 110 (Simone Nevares, trad., Universidad del Externado, Bogotá, 2014).

19 Luis Roberto Barroso, La dignidad de la persona humana en el derecho constitucional contemporáneo. La construcción de un concepto jurídico a la luz de la jurisprudencia mundial, 115 (Simone Nevares, trad., Universidad del Externado, Bogotá, 2014).

20 Luis Roberto Barroso, La dignidad de la persona humana en el derecho constitucional contemporáneo. La construcción de un concepto jurídico a la luz de la jurisprudencia mundial, 118 (Simone Nevares, trad., Universidad del Externado, Bogotá, 2014). Robert Alexy, Teoría de los derechos fundamentales (Centro de Estudios Políticos y Constitucionales, CEPC, Madrid, 2001).

21 LuIs RoBerto BARroso, La dignidad de la persona humana en el derecho constitucional contemporáneo. La construcción de un concepto jurídico a la luz de la jurisprudencia mundial, 118-119 (Simone Nevares, trad., Universidad del Externado, Bogotá, 2014). 
Finalmente, BARRoso descarta la posibilidad de que la mejor opción sea la de asimilar la dignidad como derecho fundamental, explicando que:

Si la dignidad humana fuera considerada como un derecho fundamental especifico, ella necesariamente tendría que ser ponderada con otros derechos fundamentales, lo que la pondría en una posición más débil que la que tendría en caso de que fuera utilizada como un criterio externo para evaluar posibles soluciones en caso de colisiones de derechos ${ }^{22}$.

Del registro de BARROSO, para describir con casos de violaciones a derechos fundamentales de la población carcelaria, se acoge la dignidad como valor constitucional, en razón a que la asimilación del valor intrínseco de cada individuo representa su posicionamiento como persona sujeto de respeto y de especial protección, aun cuando algunos de sus derechos se restrinjan por la privación de la libertad, como la libertad de circulación.

De esta breve reseña, se entiende que la dignidad humana es el reconocimiento de que toda persona humana, por el solo hecho de ser persona, es merecedora de un respeto especial. Esta reivindicación se ha traducido en el principio de dignidad humana que conforma el constitucionalismo actual. Aristeo García-GonzÁlez refuerza esta conclusión, cuando considera que el concepto de dignidad ha adquirido un carácter histórico, el cual se ha vinculado con la autonomía, la libertad y la igualdad como valores superiores que inspiran el ordenamiento jurídico ${ }^{23}$.

Al desplazar este debate al contexto colombiano, se encuentra que, a partir de su artículo 1, la Constitución de 1991 define el Estado colombiano como un Estado personalista ${ }^{24}$. Así lo considera CARLOS GAviRIA-DíAZ, cuando expresa: "Si un Estado se funda en el respeto

22 Luis Roberto Barroso, La dignidad de la persona humana en el derecho constitucional contemporáneo. La construcción de un concepto jurídico a la luz de la jurisprudencia mundial, 121 (Simone Nevares, trad., Universidad del Externado, Bogotá, 2014).

23 Aristeo García-GonzÁlez, La dignidad humana: núcleo duro de los derechos humanos, 28 Revista Ius, Universidad Latina de América, UNLA, párr. 4 (2008). Disponible en: http://www. unla.mx/iusunla28/, http://www.unla.mx/iusunla28/reflexion/La\%20Dignidad\%20Humana. htm

24 Colombia, Constitución Política, segunda edición corregida, 116 Gaceta Constitucional, 20 de julio de 1991. Disponible en: http://www.secretariasenado.gov.co/senado/basedoc/constitucion _politica_1991.html 
a la dignidad humana, está anunciando que va a tratar a la persona como un fin, y, por tanto, se trata de un estado personalista"25.

En igual sentido, se entiende lo propuesto por BERNARDo CARVAJAL-SÁNCHEZ ${ }^{26}$ cuando expresa que todo el conjunto de derechos fundamentales consagrados en el texto constitucional de 1991 tiene como núcleo esencial o "matriz" el principio de la dignidad humana, por ser esta el núcleo esencial de la Constitución. Este autor considera que el principio de dignidad humana se manifiesta como regla limitativa al ejercicio de las competencias, facultades, derechos y libertades de otro, es decir, establece obligaciones de abstención, de no hacer. Así: “(...) la dignidad-regla, o el derecho al respeto de la dignidad de una persona determinada, protege a la persona frente a una eventual agresión proveniente de la puissance publique, es decir, de cualquier persona de derecho público investida de ciertos poderes que no tiene ningún particular" 27.

De otra parte, en la Jurisprudencia, la Corte Constitucional ha reconocido que la dignidad humana es el fundamento de nuestro ordenamiento y, como tal, exige reglas especiales de trato para las personas; así, la dignidad aparece como un criterio de interpretación aplicable a todas las normas ${ }^{28}$. Esta es la posición que asume la Corte, por ejemplo, en la Sentencia T-881-02, cuando afirma:

Una sintesis de la configuración jurisprudencial del referente o del contenido de la expresión 'dignidad humana' como entidad normativa, puede presentarse de dos maneras: a partir de su objeto concreto de protección y a partir de su funcionalidad normativa. Al tener como punto de vista el objeto de protección del enunciado normativo 'dignidad humana', la Sala ha identificado a lo largo de la jurisprudencia de la Corte, tres lineamientos claros y diferenciables: (i) La dignidad humana entendida como autonomía o como posibilidad de diseñar un plan vital y de determinarse según sus características (vivir como quiera). (ii) La dignidad humana entendida como ciertas condiciones materiales concretas

25 Carlos Gaviria-Díaz, Igualdad, libertad y justicia, en Filosofía del derecho: ética, cultura y Constitución, 431-446 (Miguel Rujana-Quintero, comp., Bogotá, Ediciones Jurídicas Ibáñez, 1999).

26 Bernardo Carvajal-Sánchez, El principio de la dignidad de la persona humana en la jurisprudencia constitucional colombiana y francesa (Universidad Externado de Colombia, Instituto de Estudios Constitucionales Carlos Restrepo Piedrahita, ICRP, Bogotá, 2005).

27 Bernardo Carvajal-Sánchez, El principio de la dignidad de la persona humana en la jurisprudencia constitucional colombiana y francesa, 85-86 (Universidad Externado de Colombia, Instituto de Estudios Constitucionales Carlos Restrepo Piedrahita, ICRP, Bogotá, 2005).

28 Colombia, Corte Constitucional, Sentencia T-645-96, 26 de noviembre de 1996, magistrado ponente Alejandro Martínez-Caballero. Disponible en: http://www.corteconstitucional.gov. co/relatoria/1996/t-645-96.htm 
de existencia (vivir bien). Y (iii) la dignidad humana entendida como intangibilidad de los bienes no patrimoniales, integridad física e integridad moral (vivir sin humillaciones). De otro lado al tener como punto de vista la funcionalidad del enunciado normativo "dignidad humana", la Sala ha identificado tres lineamientos: (i) la dignidad humana entendida como principio fundante del ordenamiento jurídico y por tanto del Estado, y en este sentido la dignidad como valor. (ii) La dignidad humana entendida como principio constitucional. $Y$ (iii) la dignidad humana entendida como derecho fundamental autónomo ${ }^{29}$ (negrillas por fuera del texto).

Ahora bien, este principio, fuente, regla, no puede desconocerse para personas privadas de la libertad. Por el contrario, debe ser observado y respetado con mayor recelo. La Corte se ha pronunciado en repetidas ocasiones sobre el tema. En la Sentencia T-153-98 — sentencia hito por declarar el estado de cosas inconstitucional-, la Corte sostuvo:

...tanto el derecho a la dignidad como el de no recibir tratos o penas crueles, inhumanos o degradantes se ven quebrantados por el hacinamiento y las malas condiciones de la estructura física y de servicios públicos que se encuentra en los centros de reclusión; los derechos a la vida y la integridad física son vulnerados o amenazados de manera inminente por el mismo hacinamiento, por la mixtura de todas las categorías de reclusos y por la carencia de los efectivos guardias requeridos; el derecho a la familia es quebrantado por la sobrepoblación carcelaria y las deficiencias administrativas, condiciones estas que implican que los visitantes de los reclusos han de soportar prolongadas esperas, bajo las inclemencias del clima, para poder ingresar al centro, y que dificultan en grado extremo las visitas conyugales y familiares; el derecho a la salud se conculca dadas las carencias infraestructurales de las áreas sanitarias, la congestión carcelaria, la deficiencia de los servicios de agua y alcantarillado y la escasez de guardia para cumplir con las remisiones a los centros hospitalarios; los derechos al trabajo y a la educación son violados, comoquiera que un altísimo porcentaje de los reclusos no obtiene oportunidades de trabajo o de educación y que el acceso a estos derechos está condicionado por la extorsión y la corrupción; el derecho a la presunción de inocencia se quebranta en la medida en que se mezcla a los sindicados con los condenados y en que no se establecen condiciones especiales, más benévolas, para la reclusión de los primeros, etc. ${ }^{30}$.

29 Colombia, Corte Constitucional, Sentencia T-881-02, 17 de octubre de 2002. Magistrado ponente Eduardo Montealegre-Lynett. Disponible en: http://www.corteconstitucional.gov. co/relatoria/2002/t-881-02.htm

30 Colombia, Corte Constitucional, Sentencia T-153-98, 28 de abril de 1998, magistrado ponente Eduardo Cifuentes-Muñoz. Disponible en: http://www.corteconstitucional.gov.co/ 


\section{De otra parte, al estudiar la jurisprudencia de la Corte Intera- mericana de Derechos Humanos $(\mathrm{CorteIDH})^{31}$ sobre protección a}

relatoria/1998/t-153-98.htm

31 Ocho (8) sentencias de la Corte Interamericana de Derechos Humanos abordan el tema de la población carcelaria: Corte Interamericana de Derechos Humanos, CorteIDH, Caso Instituto de Reeducación del Menor vs. Paraguay, Serie C 112, Sentencia de 2 de septiembre de 2004, excepciones preliminares, fondos, reparaciones y costas. Disponible en: http://www. corteidh.or.cr/docs/casos/articulos/seriec_112_esp.pdf. Hechos del caso: se sometió a muy malas condiciones de vida a todos los niños y adolescentes del Instituto de Reeducación del Menor Coronel Panchito López, entre el 14 de agosto de 1996 y el 25 de julio de 2001. Esas condiciones de hacinamiento, falta de higiene y educación, y la mala alimentación representaron el mantenimiento de un sistema de detención contrario a los estándares internacionales respecto de la privación de la libertad de estas personas. Como consecuencia de la falta de prevención de estas condiciones por parte del Estado, se produjeron tres incendios en los que perdieron la vida 10 jóvenes, además resultaron heridos 37 más. Corte Interamericana de Derechos Humanos, CorteIDH, Caso Neira-Alegría y otros vs. Perú, Serie C 20, Sentencia de 19 de enero de 1995, fondo. Disponible en: http://www.corteidh.or.cr/docs/casos/articulos/ seriec_20_esp.pdf. Hechos del caso: el 18 de junio de 1986, tres ciudadanos estaban detenidos, en calidad de procesados, como presuntos autores del delito de terrorismo, en el establecimiento penitenciario San Juan Bautista, conocido como El Frontón, cuando se produjo un amotinamiento. Con el fin de sofocar el mismo, el gobierno delegó, mediante Decreto Supremo número 006-86-JUS, en el Comando Conjunto de las Fuerzas Armadas, el control del penal, quedando este como zona militar restringida. Corte Interamericana de Derechos Humanos, CorteIDH, Caso Durand y Ugarte vs. Perú, Serie C 68, Sentencia de 16 de agosto de 2000, fondo. Disponible en: http://www.corteidh.or.cr/docs/casos/articulos/Seriec_68_esp.pdf. Hechos del caso: dos ciudadanos fueron detenidos bajo la sospecha de su participación en actos terroristas y trasladados al mismo penal del caso anteriormente relatado, en junio de 1986; cuando se produjo la disolución del motín en ese centro penitenciario, los dos ciudadanos detenidos habían desaparecido, a pesar de que el Tribunal Correccional de Lima ordenó su libertad. Corte Interamericana de Derechos Humanos, CorteIDH, Caso Tibi vs. Ecuador, Serie C 114, Sentencia de 7 de septiembre de 2004, excepciones preliminares, fondo, reparaciones y costas. Disponible en: http://www.corteidh.or.cr/docs/casos/articulos/seriec_114_esp.pdf. Hechos del caso: el 27 de septiembre de 1995 se presentó la detención arbitraria del señor Daniel Tibi por parte de oficiales de la Policía de Quito, posteriormente fue trasladado a una cárcel en la ciudad de Guayaquil, donde permaneció hasta el 21 de enero de 1998 (28 meses) en prisión preventiva, por su supuesta participación en un caso de narcotráfico. Al momento del arresto, funcionarios estatales le incautaron al señor Tibi bienes de su propiedad. Durante su detención el señor Tibi fue torturado alrededor de siete veces por los guardias del centro penitenciario, con el fin de obtener su confesión o que se culpara a sí mismo. Corte Interamericana de Derechos Humanos, CorteIDH, Caso López-Álvarez vs. Honduras, Serie C 141, Sentencia de 1 de febrero de 2006, fondo, reparaciones y cosas. Disponible en: http:// www.corteidh.or.cr/docs/casos/articulos/seriec_141_esp.pdf. Hechos del caso: la CIDH hace precisiones importantes sobre el deber de los Estados de ser garantes de los derechos de los detenidos ofreciéndoles condiciones de vida compatibles con su dignidad. Se trató de que el señor Alfredo López-Álvarez estaba detenido en un sitio con superpoblación carcelaria, sometido a hacinamiento permanente, obligado a dormir en el suelo por un largo tiempo y en una celda reducida en tamaño, para habitar con muchos reclusos. Corte Interamericana de Derechos Humanos, CorteIDH, Caso Vélez Loor vs. Panamá, Serie C 218, sentencia de 23 de noviembre de 2010, excepciones preliminares, fondo, reparaciones y costas. Disponible en: http://www.corteidh.or.cr/docs/casos/articulos/seriec_218_esp2.pdf. Hechos del caso: el ciudadano ecuatoriano Jesús Tranquilino Vélez Loor fue detenido en Panamá y recluido en la Cárcel Pública de La Palma y el Centro Penitenciario La Joyita, sitios de reclusión con problemas, como deficiencias estructurales, suministro regular de agua, sobrepoblación penitenciaria, deficiencia de los sistemas de clasificación de las personas privadas de libertad, deficiencias de los programas de resocialización y educación. Adicional a esto, el señor Vélez 
la población carcelaria, se encontró que la CorteIDH ha concluido que el hecho de estar privado de la libertad no es una justificación para que se vulneren derechos, puesto que los Estados están en la obligación de garantizarlos a todas las personas. Por ello, prácticas como la tortura física y psicológica, la violencia sexual, las condiciones de hacinamiento inhumanas, los sistemas penitenciarios sin planificación, la no diferenciación en centros carcelarios de adultos y menores (detenidos por causas migratorias y por causas penales) y la negación de una alimentación buena y nutritiva, recursos judiciales reales, rápidos y accesibles, de atención consular en caso de requerirla, de agua potable, de servicios de aseo, de horarios de visita, de acceso a ventilación y luz constituyen faltas estatales que implican responsabilidad a la luz del Derecho Internacional. En este sentido, el caso del Penal Miguel Castro-Castro vs. Perú trató de la responsabilidad del Estado peruano por la violación de los derechos humanos de 42 reclusos que fallecieron, 175 reclusos que resultaron heridos y 322 reclusos que fueron sometidos a trato cruel,

Loor dio noticia al Estado panameño sobre actos de tortura y malos tratos ocurridos durante su detención. Corte Interamericana de Derechos Humanos, CorteIDH, Caso Mendoza y otros vs. Argentina, Serie C 260, Sentencia de 14 de mayo 2013, excepciones preliminares, fondo y reparaciones. Disponible en: http://www.corteidh.or.cr/docs/casos/articulos/seriec_260_esp. pdf. Este caso reviste mucha importancia por la situación vivida por los detenidos y por el posterior pronunciamiento de la Corte. Hechos del caso: el 17 de junio de 2011, César Alberto Mendoza y otros son sometidos a condenas arbitrarias por hechos que ocurrieron cuando aún eran niños. También se alegaron violaciones de derechos humanos, ocurridas durante el cumplimiento de las condenas, bajo la custodia del Estado. Se dice que Ricardo David Videla-Fernández y Saúl Cristian Roldán-Cajal fueron sometidos a condiciones inhumanas de detención incompatibles con su dignidad humana en la Penitenciaría Provincial de Mendoza, situación que finalmente dio lugar a la muerte de Ricardo David Videla-Fernández, sin que el Estado adoptara medidas razonables para prevenir su muerte y, luego, investigarla efectivamente. Por otra parte, Lucas Matías Mendoza perdió la visión sin que el Estado le hubiera otorgado tratamiento médico, mientras que Claudio David Núñez y Lucas Matías Mendoza fueron víctimas de actos de tortura estando privados de la libertad. Corte Interamericana de Derechos Humanos, CorteIDH, Caso Pacheco Teruel y otros vs. Honduras, Serie C 241, Sentencia de 27 de abril de 2012, fondo, reparaciones y costas. Disponible en: http:// corteidh.or.cr/docs/casos/articulos/seriec_241_esp.pdf. Hechos del caso: la CIDH declaró al Estado de Honduras responsable internacionalmente por la muerte de 107 internos privados de libertad, con motivo del incendio ocurrido el 17 de mayo de 2004 en la bartolina o celda 19 del Centro Penal de San Pedro Sula. Esto se dio debido a que había una serie de deficiencias estructurales en este centro penitenciario. Las condiciones de esta cárcel eran contrarias a la dignidad humana y así quedó plasmado en el expediente. Había problemas graves como el inadecuado servicio de agua, la carencia de servicio médico, la alimentación estaba muy por debajo de los estándares, sobrepoblación, hacinamiento, falta de ventilación, sistema eléctrico deplorable y, debido a la sobrecarga de aparatos, se generó un corto circuito que provocó el incendio. Como problema adicional no se contaba con un sistema de prevención de incendios o algún tipo de contingencia resultante. Por esto, cuando se inició el incendio, se produjo un gran número de muertes a causa de asfixia por sofocación y quemaduras graves. 
inhumano y degradante ${ }^{32}$. Sobre el caso, al analizar el alcance de las violaciones derivadas de los hechos, entre las que se incluye la condición de desnudez forzada a la que fueron sometidas varias reclusas durante un período prolongado, la CIDH señaló:

\begin{abstract}
(...)El Tribunal estima que esas mujeres, además de recibir un trato violatorio de su dignidad personal, también fueron víctimas de violencia sexual, ya que estuvieron desnudas y cubiertas con tan solo una sábana, estando rodeadas de hombres armados, quienes aparentemente eran miembros de las fuerzas de seguridad del Estado. Lo que califica este tratamiento de violencia sexual es que las mujeres fueron constantemente observadas por hombres ${ }^{33}$.
\end{abstract}

Según el criterio del Tribunal Interamericano, con fundamento en la Convención de Belem do Pará ${ }^{34}$, resultan inadmisibles y especialmente graves ciertas violaciones contra las mujeres, en su calidad de personas especialmente vulnerables y discriminadas desde varios ámbitos.

Como conclusión de este apartado, la dignidad humana es el valor que fundamenta los derechos y a partir de la cual se protege judicialmente a la población vulnerada en sus derechos.

32 Corte Interamericana de Derechos Humanos, CorteIDH, Caso del Penal Miguel Castro-Castro vs. Perú, Serie C 160, Sentencia de 25 de noviembre de 2006, fondo, reparaciones y costas. Disponible en: http://www.corteidh.or.cr/docs/casos/articulos/seriec_160_esp.pdf. Perú vivió un conflicto armado interno en los años 80 entre el grupo Sendero Luminoso y el Estado. En ese contexto, el 5 de abril de 1992, el presidente Alberto Fujimori [28 de julio de 1990-21 de noviembre de 2000] realizó un golpe de Estado y acabó con la estructura democrática estatal tal como se conocía. Estando en el poder, con el ánimo de reprimir a los grupos subversivos y terroristas, implementó en las cárceles una serie de prácticas vulneradoras de los derechos humanos, como ejecuciones extrajudiciales, tratos crueles y tortura, que supuestamente buscaban acabar con los miembros y partidarios de Sendero Luminoso. Así las cosas, se creó el penal Miguel Castro-Castro, donde concentraron a procesados y condenados por delitos de terrorismo o traición a la patria, presuntamente miembros de Sendero Luminoso y donde, posteriormente, se ejecutó el Operativo Mudanza 1, un ataque premeditado contra los 450 hombres y 135 mujeres de los pabellones $1 \mathrm{~A}$ y $4 \mathrm{~B}$, a quienes les vulneraron los derechos a la vida, integridad física y sexual.

33 Corte Interamericana de Derechos Humanos, CorteIDH, Caso del Penal Miguel Castro-Castro vs. Perú, Serie C 160, Sentencia de 25 de noviembre de 2006, fondo, reparaciones y costas, párr. 306. Disponible en: http://www.corteidh.or.cr/docs/casos/articulos/seriec_160_esp.pdf

34 Organización de Estados Americanos, OEA, Convención Interamericana para Prevenir, Sancionar y Erradicar la Violencia contra la Mujer, Convención de Belem Do Pará, Brasil, 9 de junio de 1994. Disponible en: http://oas.org/juridico/spanish/tratados/a-61.html 


\section{CÁRCELES EN COLOMBIA: ESCENARIOS DE DEGRADACIÓN}

En enero de 2016, Colombia contaba con 138 cárceles $^{35}$ para 77.953 reclusos y una población real de 120.736 , por lo que el hacinamiento carcelario del país tenía un índice del 54,9\%, pues supera en $\mathbf{4 3 . 2 5 1}$ internos la capacidad del Establecimiento Reclusorio de Orden Nacional e Internacional ${ }^{36}$. Lo anterior evidencia la vulneración de la dignidad de los reclusos y otros derechos, como la salud por la proliferación de enfermedades contagiosas, producto del hacinamiento. A esto se le añade que solo se cuenta con una entidad prestadora de servicios de salud, EPS, CAPRECOM EPS, en liquidación, para la atención de la salud de los reclusos y es una de las que menos recursos económicos poseen.

Las cifras mencionadas no son casualidad, teniendo en cuenta el aumento constante de condenados y sindicados con detención preventiva que se ha producido en el marco de los procesos penales en Colombia, pues en cuanto a los sindicados en prisión solo se registró una tendencia a la baja entre 2004 y 2007, con la entrada en vigencia del sistema penal acusatorio establecido por medio del Acto Legislativo 003 de $2002^{37}$ y con la Ley 906 de $2004^{38}$ y la Ley 1142 de $2007^{39}$, que flexibilizan la detención preventiva ${ }^{40}$.

35 Instituto Nacional Penitenciario y Carcelario, INPEC, Estadisticas a enero de 2016 (Instituto Nacional Penitenciario y Carcelario, INPEC, Bogotá, 2016). Disponible en: http://www.inpec. gov.co/portal/page/portal/INPEC_CONTENIDO/NOTICIAS\%20Y\%20NORMATIVIDAD/ ESTADISTICAS/Tab/ESTADISTICA \%20A\%20ENERO $\% 20$ DE $\% 202016 \% 20$ (Publicaci\%F3n).xls

36 Instituto Nacional Penitenciario y Carcelario, INPEC, Series históricas enero de 2016 (Instituto Nacional Penitenciario y Carcelario, INPEC, Bogotá, 2016). Disponible en: http://www.inpec. gov.co/portal/page/portal/INPEC_CONTENIDO/NOTICIAS $\% 20 \mathrm{Y} \% 20$ NORMATIVIDAD/ ESTADISTICAS/Tab/SERIES\%20HIST\%D3RICAS\%20ENERO\%20DE\%202016.xlsx

37 Colombia, Acto Legislativo 003 de 2002, por el cual se reforma la Constitución Nacional, 45.040 Diario Oficial, 20 de diciembre de 2002. Disponible en: http://www.secretariasenado. gov.co/senado/basedoc/acto_legislativo_03_2002.html

38 Colombia, Ley 906 de 2004, por la cual se expide el Código de Procedimiento Penal, 45.658 Diario Oficial, 1 de septiembre de 2004, corregida de conformidad con el Decreto 2770 de 2004. Disponible en: http://www.secretariasenado.gov.co/senado/basedoc/ley_0906_2004. html

39 Colombia, Ley 1142 de 2007, por medio de la cual se reforman parcialmente las Leyes 906 de 2004, 599 de 2000 y 600 de 2000 y se adoptan medidas para la prevención y represión de la actividad delictiva de especial impacto para la convivencia y seguridad ciudadana, 46.673 Diario Oficial, 28 de julio de 2007. Disponible en: http://www.secretariasenado.gov.co/senado/ basedoc/ley_1142_2007.html

40 Manuel Alejandro Iturralde-Sánchez \& Libardo José Ariza-Higuera, Los muros de la infamia: prisiones en Colombia y América Latina, 164-165 (Uniandes, Bogotá, 2011). 
De igual manera, la pobre respuesta estatal a la delincuencia desde una perspectiva no punitiva, agrava el hacinamiento carcelario. La Corte Suprema de Justicia ha considerado que Colombia no cuenta con una política criminal clara, pero sí parece que hubiera un acuerdo para responder con punitivismo exacerbado a cualquier problema que se presente y dejar en un segundo lugar las medidas preventivas y de trabajo social ${ }^{41}$. El populismo punitivo ${ }^{42}$ y el derecho penal simbólico ${ }^{43}$ no parecen remediar la situación. Constantemente, ocurre la presentación de proyectos de ley que tienden a endurecer las penas, como el radicado en febrero de 2015 "por medio del cual se modifica el artículo 34 de la Constitución Política, suprimiendo la prohibición de la pena de prisión perpetua [cadena perpetua]" que fue archivado por vencimiento de términos en junio del mismo año, o la Ley Rosa Elvira Cely que, al buscar erradicar y prevenir la violencia contra la mujer, penan el feminicidio ${ }^{44}$. Las anteriores medidas no resuelven los problemas existentes en la sociedad colombiana, sino por el contrario, parecen destinadas a calmar el clamor de justicia de la población a costa de un agravamiento de la situación carcelaria actual.

La situación de los presos en Colombia ha sido tal que la Corte ha declarado en tres ocasiones el estado de cosas inconstitucional (Sentencia T-153-98, T-388-13 y T-208-15), teniendo en cuenta las crisis originadas por las condiciones de hacinamiento y vulneración de derechos a la que se han visto sometidas las personas privadas de la libertad en las cárceles colombianas. En la Sentencia T-38813, se dijo que las cárceles se habían convertido en vertederos de seres humanos antes que instituciones que respeten los derechos

41 Manuel Alejandro Iturralde-Sánchez \& Libardo José Ariza-Higuera, los muros de la infamia: prisiones en Colombia y América Latina, 180 (Uniandes, Bogotá, 2011).

42 Para un concepto de populismo punitivo, David Garland, La cultura del control. Crimen y orden social en la sociedad contemporánea, 48-50 (MÁxımo Sozzo, trad., Gedisa, Barcelona, 2005). Mauricio Martínez-Sánchez, Populismo punitivo, mayorías y víctimas, 2 Nomos, Revista de Derechos Fundamentales, Universidad de Viña del Mar, 183-199 (2008). Disponible en: http://www.derechosfundamentales.cl/revista/02.183-199.Martinez.pdf

43 Para un concepto de derecho penal simbólico, Emiro Sandoval-Huertas, Penología, partes general y especial (Ediciones Jurídicas Gustavo Ibáñez, Bogotá, 1996).

44 Redacción política, Aprobada ley Rosa Elvira Cely que castiga hasta con 50 años los feminicidios, El Espectador (2 de junio de 2015). Disponible en: http://www.elespectador.com/noticias/ politica/aprobada-ley-rosa-elvira-cely-castiga-hasta-50-anos-los-articulo-564105 
y la dignidad humana, haciendo referencia a que se conserva la situación "dantesca o infernal” en las cárceles del país ${ }^{45}$.

\section{JURISPRUDENCIA Y DERECHOS}

En esta parte, se presenta un registro cuantitativo y cualitativo sobre los fallos de revisión de tutela expedidos por la Corte entre 1992 y 2012 (224 sentencias de tutela). Esto genera dos reflexiones: la habitual vulneración de los derechos fundamentales de la población carcelaria y el grado de intervencionismo asumido por la Corte, ante la ineficiencia del Ejecutivo y frente al complejo estado del sistema penitenciario del país. De manera específica, los hechos por los que se presentan las solicitudes de protección son diversos: problemas de salud física y emocional ocasionados por la privación de la libertad; hacinamiento carcelario y maltrato; ausencia de servicios médicos; mala alimentación; discriminación en razón al género y la religión; arbitrariedad en los traslados, lo cual genera que la población carcelaria se aleje de su familia; requisas invasivas e intimidantes a los familiares durante los días de visitas; crueles y absurdas reglas de disciplina.

Las cifras. Cuantitativamente, en 1992 se expidieron 5 sentencias de tutela (ST); en 19939 ST; en los años 1994, 1995 y 1999 se revisaron un promedio de 7 u 8 ST por año. En los años siguientes 1996-1998, 2004, 2007-2012 se revisaron un promedio de 13 a 19 ST por año. Los años más prolíficos fueron los años 2000, 2001, 2002, 2003 en razón a que se llegaron a revisar un promedio de 20 sentencias por año; y los años 2005 y 2006 en los que se revisaron más de 30 sentencias por año.

A continuación, presentamos una relación de las sentencias por año con sus respectivos magistrados ponentes.

45 Colombia, Corte Constitucional, Sentencia T-388-13, 28 de junio de 2013, magistrada ponente María Victoria Calle-Correa. Disponible en: http://www.corteconstitucional.gov.co/ relatoria/2013/t-388-13.htm 
Tabla 1

Relación de sentencias de tutela y unificación de la Corte Constitucional

\begin{tabular}{|c|c|}
\hline Año & Sentencias \\
\hline 1992 & $\begin{array}{l}\text { T-424-92, } 24 \text { de junio de 1992, Fabio Morón-Díaz } \\
\text { T-522-92, } 19 \text { de septiembre de 1992, Alejandro Martínez- } \\
\text { Caballero } \\
\text { T-538-92, } 23 \text { de septiembre de 1992, Simón Rodríguez- } \\
\text { Rodríguez } \\
\text { T-596-92, } 10 \text { de diciembre de 1992, Ciro Angarita-Barón } \\
\text { T-601-92, } 11 \text { de diciembre de 1992, Eduardo Cifuentes- } \\
\text { Muñoz }\end{array}$ \\
\hline 1993 & $\begin{array}{l}\text { T-009-93, } 18 \text { de enero de 1993, Eduardo Cifuentes-Muñoz } \\
\text { T-121-93, } 29 \text { de marzo de 1993, Vladimiro Naranjo-Mesa } \\
\text { T-219-93, } 9 \text { de junio de 1993, Antonio Barrera-Carbonell } \\
\text { T-222-93, } 15 \text { de junio de 1993, Jorge Arango-Mejía } \\
\text { T-273-93, } 14 \text { de julio de 1993, Carlos Gaviria-Díaz } \\
\text { T-349-93, } 27 \text { de agosto de 1993, José Gregorio } \\
\text { Hernández-Galindo } \\
\text { T-388-93, } 15 \text { de septiembre de 1993, Hernando Herrera- } \\
\text { Vergara } \\
\text { T-494-93, } 28 \text { de octubre de 1993, Vladimiro Naranjo- } \\
\text { Mesa } \\
\text { T-575-93, } 28 \text { de octubre de 1993, Eduardo Cifuentes- } \\
\text { Muñoz }\end{array}$ \\
\hline 1994 & $\begin{array}{l}\text { T-066-94, } 17 \text { de febrero de 1994, Hernando Herrera- } \\
\text { Vergara } \\
\text { T-193-94, } 20 \text { de abril de 1994, Jorge Arango-Mejía } \\
\text { T-235-94, } 17 \text { de mayo de 1994, Antonio Barrera-Carbonell } \\
\text { T-277-94, } 15 \text { de junio de 1994, Carlos Gaviria-Díaz } \\
\text { T-324-94, } 14 \text { de julio de 1994, Eduardo Cifuentes-Muñoz } \\
\text { T-420-94, } 23 \text { de septiembre de 1994, Eduardo Cifuentes- } \\
\text { Muñoz } \\
\text { T-501-94, } 4 \text { de noviembre de 1994, Vladimiro Naranjo- } \\
\text { Mesa } \\
\text { T-502-94, } 4 \text { de noviembre de 1994, Antonio Barrera- } \\
\text { Carbonell }\end{array}$ \\
\hline
\end{tabular}




\begin{tabular}{|c|c|}
\hline Año & Sentencias \\
\hline 1995 & $\begin{array}{l}\text { T-065-95, } 21 \text { de febrero de 1995, Alejandro Martínez- } \\
\text { Caballero } \\
\text { T-118-95, } 16 \text { de marzo de 1995, José Gregorio Hernández- } \\
\text { Galindo } \\
\text { T-121-95, } 21 \text { de marzo de 1995, José Gregorio Hernández- } \\
\text { Galindo } \\
\text { T-324-95, } 26 \text { de julio de 1995, Alejandro Martínez- } \\
\text { Caballero } \\
\text { T-408-95, } 12 \text { de septiembre de 1995, Eduardo Cifuentes- } \\
\text { Muñoz } \\
\text { T-473-95, } 19 \text { de octubre de 1995, Fabio Morón-Díaz } \\
\text { T-555-95, } 28 \text { de noviembre de 1995, Carlos Gaviria-Díaz } \\
\text { SU327-95, } 27 \text { de julio de 1995, Carlos Gaviria-Díaz }\end{array}$ \\
\hline 1996 & $\begin{array}{l}\text { T-066-96, } 22 \text { de febrero de 1996, Fabio Morón-Díaz } \\
\text { T-129-96, } 27 \text { de marzo de 1996, Vladimiro Naranjo-Mesa } \\
\text { T-207-96, } 9 \text { de mayo de 1996, Hernando Herrera-Vergara } \\
\text { T-247-96, } 3 \text { de junio de 1996, José Gregorio Hernández- } \\
\text { Galindo } \\
\text { T-303-96, } 10 \text { de julio de 1996, Jorge Arango-Mejía } \\
\text { T-415-96, } 4 \text { de septiembre de 1996, Eduardo Cifuentes- } \\
\text { Muñoz } \\
\text { T-470-96, } 24 \text { de septiembre de 1996, Eduardo Cifuentes- } \\
\text { Muñoz } \\
\text { T-588-96, } 5 \text { de noviembre de 1996, Eduardo Cifuentes- } \\
\text { Muñoz } \\
\text { T-645-96, } 26 \text { de noviembre de 1996, Alejandro Martínez- } \\
\text { Caballero } \\
\text { T-654-96, } 27 \text { de noviembre de 1996, Carlos Gaviria-Díaz } \\
\text { T-680-96, } 4 \text { de diciembre de 1996, Carlos Gaviria-Díaz } \\
\text { T-705-96, } 9 \text { de diciembre de 1996, Eduardo Cifuentes- } \\
\text { Muñoz } \\
\text { T-706-96, } 9 \text { de diciembre de 1996, Eduardo Cifuentes- } \\
\text { Muñoz } \\
\text { T-714-96, } 16 \text { de diciembre de 1996, Eduardo Cifuentes- } \\
\text { Muñoz, } \\
\text { SU707-96, } 9 \text { de diciembre de 1996, Hernando Herrera- } \\
\text { Vergara }\end{array}$ \\
\hline
\end{tabular}




\begin{tabular}{|c|c|}
\hline Año & Sentencias \\
\hline 1997 & $\begin{array}{l}\text { T-021-97, } 24 \text { de enero de 1997, Vladimiro Naranjo-Mesa } \\
\text { T-101-97, } 4 \text { de marzo de 1997, Fabio Morón-Díaz } \\
\text { T-190-97, } 10 \text { de abril de 1997, Alejandro Martínez- } \\
\text { Caballero } \\
\text { T-263-97, } 28 \text { de mayo de 1997, Hernando Herrera-Vergara } \\
\text { T-305-97, } 20 \text { de junio de 1997, José Gregorio Hernández- } \\
\text { Galindo } \\
\text { T-317-97, } 25 \text { de junio de 1997, Vladimiro Naranjo-Mesa } \\
\text { T-342-97, } 18 \text { de julio de 1997, Hernando Herrera-Vergara } \\
\text { T-359-97, } 5 \text { de agosto de 1997, Jorge Arango-Mejía } \\
\text { T-361-97, } 5 \text { de agosto de 1997, Carlos Gaviria-Díaz } \\
\text { T-415-97, } 28 \text { de agosto de 1997, Hernando Herrera- } \\
\text { Vergara } \\
\text { T-435-97, } 8 \text { de septiembre de 1997, José Gregorio } \\
\text { Hernández-Galindo } \\
\text { T-483-97, } 29 \text { de septiembre de 1997, Vladimiro Naranjo- } \\
\text { Mesa } \\
\text { T-605-97, } 21 \text { de noviembre de 1997, Vladimiro Naranjo- } \\
\text { Mesa }\end{array}$ \\
\hline 1998 & $\begin{array}{l}\text { T-150-98, } 27 \text { de abril de 1998, Alejandro Martínez- } \\
\text { Caballero } \\
\text { T-153-98, } 28 \text { de abril de 1998, Eduardo Cifuentes-Muñoz } \\
\text { T-279-98, } 4 \text { de junio de 1998, Hernando Herrera-Vergara } \\
\text { T-296-98, } 16 \text { de junio de 1998, Alejandro Martínez- } \\
\text { Caballero } \\
\text { T-349-98, } 10 \text { de julio de 1998, Hernando Herrera-Vergara } \\
\text { T-389-98, } 31 \text { de julio de 1998, Fabio Morón-Díaz } \\
\text { T-487-98, } 10 \text { de septiembre de 1998, Alfredo Beltrán- } \\
\text { Sierra } \\
\text { T-490-98, } 11 \text { de septiembre de 1998, Vladimiro Naranjo- } \\
\text { Mesa } \\
\text { T-517-98, } 21 \text { de septiembre de 1998, Alejandro Martínez- } \\
\text { Caballero } \\
\text { T-535-98, } 30 \text { de septiembre de 1998, José Gregorio } \\
\text { Hernández-Galindo } \\
\text { T-583-98, } 19 \text { de octubre de 1998, José Gregorio } \\
\text { Hernández-Galindo } \\
\text { T-590-98, } 20 \text { de octubre de 1998, Alejandro Martínez- } \\
\text { Caballero } \\
\text { T-606-98, } 27 \text { de octubre de 1998, José Gregorio } \\
\text { Hernández-Galindo } \\
\text { T-607-98, } 27 \text { de octubre de 1998, José Gregorio } \\
\text { Hernández-Galindo }\end{array}$ \\
\hline
\end{tabular}




\begin{tabular}{|c|c|}
\hline Año & Sentencias \\
\hline 1999 & $\begin{array}{l}\text { T-063-99, } 8 \text { de febrero de 1999, Vladimiro Naranjo-Mesa } \\
\text { T-208-99, } 12 \text { de abril de 1999, Vladimiro Naranjo-Mesa } \\
\text { T-258-99, } 21 \text { de abril de 1999, Antonio Barrera-Carbonell } \\
\text { T-265-99, } 23 \text { de abril de 1999, Eduardo Cifuentes-Muñoz } \\
\text { T-524-99, } 22 \text { de julio de 1999, Alfredo Beltrán-Sierra } \\
\text { T-530-99, } 26 \text { de julio de 1999, Vladimiro Naranjo-Mesa } \\
\text { T-946-99, } 29 \text { de noviembre de 1999, Antonio Barrera- } \\
\text { Carbonell }\end{array}$ \\
\hline 2000 & $\begin{array}{l}\text { T-144-00, } 22 \text { de febrero de 2000, Antonio Barrera- } \\
\text { Carbonell } \\
\text { T-256-00, } 6 \text { de marzo de 2000, José Gregorio Hernández- } \\
\text { Galindo } \\
\text { T-257-00, } 6 \text { de marzo de 2000, José Gregorio Hernández- } \\
\text { Galindo } \\
\text { T-334-00, } 23 \text { de marzo de 2000, Eduardo Cifuentes- } \\
\text { Muñoz } \\
\text { T-352-00, } 27 \text { de marzo de 2000, José Gregorio } \\
\text { Hernández-Galindo } \\
\text { T-415-00, } 11 \text { de abril de 2000, Carlos Gaviria-Díaz } \\
\text { T-592-00, } 18 \text { de mayo de 2000, Alfredo Beltrán-Sierra } \\
\text { T-607-00, } 25 \text { de mayo de 2000, Carlos Gaviria-Díaz } \\
\text { T-611-00, } 29 \text { de mayo de 2000, Fabio Morón-Díaz } \\
\text { T-847-00, } 6 \text { de julio de 2000, Carlos Gaviria-Díaz } \\
\text { T-966-00, } 31 \text { de julio de 2000, Eduardo Cifuentes-Muñoz } \\
\text { T-979-00, } 31 \text { de julio de 2000, Alejandro Martínez- } \\
\text { Caballero } \\
\text { T-1003-00, } 3 \text { de agosto de 2000, Álvaro Tafur-Galvis } \\
\text { T-1275-00, } 21 \text { de septiembre de 2000, Carlos Gaviria-Díaz } \\
\text { T-1399-00, } 19 \text { de octubre de 2000, Alfredo Beltrán-Sierra } \\
\text { T-1499-00, } 2 \text { de noviembre de 2000, Martha Victoria } \\
\text { Sáchica-Méndez } \\
\text { T-1518-00, } 9 \text { de noviembre de 2000, José Gregorio } \\
\text { Hernández-Galindo } \\
\text { T-1574-00, } 14 \text { de noviembre de 2000, Fabio Morón-Díaz } \\
\text { T-1606-00, } 21 \text { de noviembre de 2000, Fabio Morón-Díaz } \\
\text { T-1670-00, } 5 \text { de diciembre de 2000, Carlos Gaviria-Díaz } \\
\text { T-1705-00, } 11 \text { de diciembre de 2000, Jairo Charry-Rivas } \\
\text { T-1739-00, } 11 \text { de diciembre de 2000, Cristina Pardo } \\
\text { SU1722-00, } 12 \text { de diciembre de 2000, Jairo Charry-Rivas }\end{array}$ \\
\hline
\end{tabular}




\begin{tabular}{|c|c|}
\hline Año & Sentencias \\
\hline 2001 & $\begin{array}{l}\text { T-233-01, } 26 \text { de febrero de 2001, Eduardo Montealegre- } \\
\text { Lynett } \\
\text { T-358-01, } 2 \text { de abril de 2001, Alfredo Beltrán-Sierra } \\
\text { T-495-01, } 11 \text { de mayo de 2001, Rodrigo Escobar-Gil } \\
\text { T-521-01, } 18 \text { de mayo de 2001, Manuel José Cepeda- } \\
\text { Espinosa } \\
\text { T-533-01, } 21 \text { de mayo de 2001, Jaime Cordoba-Triviño } \\
\text { T-702-01, } 5 \text { de julio de 2001, Marco Gerardo Monroy- } \\
\text { Cabra } \\
\text { T-728-01, } 26 \text { de febrero de 2001, Rodrigo Escobar-Gil } \\
\text { T-759-01, } 17 \text { de julio de 2001, Jaime Araújo-Rentería } \\
\text { T-773-01, } 24 \text { de julio de 2001, Clara Inés Vargas- } \\
\text { Hernández } \\
\text { T-842-01, } 9 \text { de agosto de 2001, Álvaro Tafur-Galvis } \\
\text { T-879-01, } 16 \text { de agosto de 2001, Clara Inés Vargas- } \\
\text { Hernández } \\
\text { T-880-01, } 16 \text { de agosto de 2001, Clara Inés Vargas- } \\
\text { Hernández } \\
\text { T-904-01, } 26 \text { de febrero de 2001, Jaime Córdoba-Triviño } \\
\text { T-941-01, } 3 \text { de septiembre de 2001, Jaime Araújo-Rentería } \\
\text { T-944-01, } 4 \text { de septiembre de 2001, Clara Inés Vargas- } \\
\text { Hernández } \\
\text { T-1077-01, } 11 \text { de octubre de 2001, Jaime Araújo-Rentería } \\
\text { T-1171-01, } 2 \text { de noviembre de 2001, Rodrigo Escobar-Gil } \\
\text { T-1180-01, } 8 \text { de noviembre de 2001, Marco Gerardo } \\
\text { Monroy-Cabra } \\
\text { T-1223-01, } 22 \text { de noviembre de 2001, Álvaro Tafur-Galvis } \\
\text { T-1226-01, } 22 \text { de noviembre de 2001, Alfredo Beltrán- } \\
\text { Sierra } \\
\text { T-1235-01, } 22 \text { de noviembre de 2001, Jaime Araújo- } \\
\text { Rentería } \\
\text { T-1307-01, } 6 \text { de diciembre de 2001, Marco Gerardo } \\
\text { Monroy-Cabra } \\
\text { T-1308-01, } 7 \text { de diciembre de 2001, Clara Inés Vargas- } \\
\text { Hernández } \\
\text { T-1345-01, } 11 \text { de diciembre de 2001, Jaime Córdoba- } \\
\text { Triviño } \\
\text { SU1299-01, } 6 \text { de diciembre de 2001, Manuel José Cepeda- } \\
\text { Espinosa }\end{array}$ \\
\hline
\end{tabular}




\begin{tabular}{|c|c|}
\hline Año & Sentencias \\
\hline 2002 & $\begin{array}{l}\text { T-020-02, } 23 \text { de enero de 2002, Jaime Araújo-Rentería } \\
\text { T-022-02, } 24 \text { de enero de 2002, Allvaro Tafur-Galvis } \\
\text { T-062-02, } 6 \text { de febrero de 2002, Clara Inés Vargas- } \\
\text { Hernández } \\
\text { T-077-02, } 8 \text { de febrero de 2002, Manuel José Cepeda- } \\
\text { Espinosa } \\
\text { T-133-02, } 28 \text { de febrero de 2002, Álvaro Tafur-Galvis } \\
\text { T-169-02, } 8 \text { de marzo de 2002, Manuel José Cepeda- } \\
\text { Espinosa } \\
\text { T-239-02, } 5 \text { de abril de 2002, Alfredo Beltrán-Sierra } \\
\text { T-269-02, } 18 \text { de abril de 2002, Marco Gerardo Monroy- } \\
\text { Cabra } \\
\text { T-349-02, } 9 \text { de mayo de 2002, Jaime Araújo-Rentería } \\
\text { T-399-02, } 23 \text { de mayo de 2002, Álvaro Tafur-Galvis } \\
\text { T-461-02, } 13 \text { de junio de 2002, Álvaro Tafur-Galvis } \\
\text { T-698-02, } 29 \text { de agosto de 2002, Jaime Araújo-Rentería } \\
\text { T-705-02, } 29 \text { de agosto de 2002, Manuel José Cepeda- } \\
\text { Espinosa } \\
\text { T-722-02, } 5 \text { de septiembre de 2002, Marco Gerardo } \\
\text { Monroy-Cabra } \\
\text { T-775-02, } 19 \text { de septiembre de 2002, Marco Gerardo } \\
\text { Monroy-Cabra } \\
\text { T-785-02, } 19 \text { de septiembre de 2002, Clara Inés Vargas- } \\
\text { Hernández } \\
\text { T-839-02, } 10 \text { de octubre de 2002, Álvaro Tafur-Galvis } \\
\text { T-881-02, } 17 \text { de octubre de 2002. Eduardo Montealegre- } \\
\text { Lynett } \\
\text { T-894-02, } 24 \text { de octubre de 2002, Álvaro Tafur-Galvis } \\
\text { T-895-02, } 24 \text { de octubre de 2002, Álvaro Tafur-Galvis } \\
\text { T-958-02, } 7 \text { de noviembre de 2002, Eduardo Montealegre- } \\
\text { Lynett } \\
\text { T-986-02, } 14 \text { de noviembre de 2002, Alfredo Beltrán- } \\
\text { Sierra } \\
\text { T-1002-02, } 15 \text { de noviembre de 2002, Manuel José } \\
\text { Cepeda-Espinosa } \\
\text { T-1006-02, } 15 \text { de noviembre de 2002, Rodrigo Escobar- } \\
\text { Gil } \\
\text { T-1045-02, } 28 \text { de noviembre de 2002, Jaime Araújo- } \\
\text { Rentería } \\
\text { T-1108-02, } 5 \text { de diciembre de 2002, Álvaro Tafur-Galvis }\end{array}$ \\
\hline
\end{tabular}




\begin{tabular}{|c|c|}
\hline Año & Sentencias \\
\hline 2003 & $\begin{array}{l}\text { T-023-03, } 23 \text { de enero de 2003, Clara Inés Vargas- } \\
\text { Hernández } \\
\text { T-054-03, } 30 \text { de enero de 2003, Álvaro Tafur-Galvis } \\
\text { T-085-03, } 6 \text { de febrero de 2003, Manuel José Cepeda- } \\
\text { Espinosa } \\
\text { T-172-03, } 27 \text { de febrero de 2003, Jaime Córdoba-Triviño } \\
\text { T-471-03, } 5 \text { de junio de 2003, Avlvaro Tafur-Galvis } \\
\text { T-490-03, } 6 \text { de junio de 2003, Clara Inés Vargas- } \\
\text { Hernández } \\
\text { T-499-03, } 12 \text { de junio de 2003, Álvaro Tafur-Galvis } \\
\text { T-545-03, } 9 \text { de julio de 2003, Manuel José Cepeda- } \\
\text { Espinosa } \\
\text { T-638-03, } 31 \text { de julio de 2003, Álvaro Tafur-Galvis } \\
\text { T-687-03, } 8 \text { de agosto de 2003, Eduardo Montealegre- } \\
\text { Lynett } \\
\text { T-703-03, } 14 \text { de agosto de 2003, Clara Inés Vargas- } \\
\text { Hernández } \\
\text { T-718-03, } 20 \text { de agosto de 2003, Manuel José Cepeda- } \\
\text { Espinosa } \\
\text { T-750-03, } 28 \text { de agosto de 2003, Jaime Araújo-Rentería } \\
\text { T-758-03, } 28 \text { de agosto de 2003, Álvaro Tafur-Galvis } \\
\text { T-1025-03, } 30 \text { de octubre de 2003, Alfredo Beltrán-Sierra } \\
\text {-1030-03, } 30 \text { de octubre de 2003, Clara Inés Vargas- } \\
\text { Hernández } \\
\text { T-1082-03, } 13 \text { de noviembre de 2003, Manuel José } \\
\text { Cepeda-Espinosa } \\
\text { T-1168-03, } 4 \text { de diciembre de 2003, Clara Inés Vargas- } \\
\text { Hernández } \\
\text { T-1174-03, } 4 \text { de diciembre de 2003, Jaime Araújo-Rentería } \\
\text { T-1190-03, } 4 \text { de diciembre de 2003, Eduardo Montealegre- } \\
\text { Lynett } \\
\text { T-1204-03, } 10 \text { de diciembre de 2003, Alfredo Beltrán- } \\
\text { Sierra } \\
\text { T-1206-03, } 11 \text { de diciembre de 2003, Manuel José Cepeda- } \\
\text { Espinosa }\end{array}$ \\
\hline
\end{tabular}




\begin{tabular}{|c|l|}
\hline Año & \multicolumn{1}{|c|}{ Sentencias } \\
\hline 2004 & T-003-04, 15 de enero de 2004, Alfredo Beltrán-Sierra \\
& T-388-04, 29 de abril de 2004, Jaime Araújo-Rentería \\
& T-471-04, 17 de mayo de 2004, Rodrigo Escobar-Gil \\
& T-490-04, 20 de mayo de 2004, Eduardo Montealegre- \\
& Lynett \\
& T-639-04, 1 de julio de 2004, Rodrigo Escobar-Gil \\
& T-679-04, 15 de julio de 2004, Jaime Córdoba-Triviño \\
& T-690-04, 22 de julio de 2004, Álvaro Tafur-Galvis \\
& T-860-04, 2 de septiembre de 2004, Clara Inés Vargas- \\
& Hernández \\
& T-1045-04, 21 de octubre de 2004, Humberto Antonio \\
& Sierra-Porto \\
& T-1060-04, 28 de octubre de 2004, Manuel José Cepeda- \\
& Espinosa \\
& T-1074-04, 28 de octubre de 2004, Clara Inés Vargas- \\
& Hernández \\
& T-1096-04, 4 de noviembre de 2004, Manuel José Cepeda- \\
& Espinosa \\
& T-1134-04, 11 de noviembre de 2004, Alfredo Beltrán- \\
& Sierra \\
& T-1239-04, 9 de diciembre de 2004, Rodrigo Escobar-Gil \\
\hline
\end{tabular}




\begin{tabular}{|c|c|}
\hline Año & Sentencias \\
\hline 2005 & $\begin{array}{l}\text { T-052-05, } 28 \text { de enero de 2005, Jaime Córdoba-Triviño } \\
\text { T-066-05, } 28 \text { de enero de 2005, Rodrigo Escobar-Gil } \\
\text { T-134-05, } 17 \text { de febrero de 2005, Manuel José Cepeda- } \\
\text { Espinosa } \\
\text { T-254-05, } 17 \text { de marzo de 2005, Jaime Araújo-Rentería } \\
\text { T-274-05, } 17 \text { de marzo de 2005, Humberto Antonio } \\
\text { Sierra-Porto } \\
\text { T-507-05, } 19 \text { de mayo de 2005, Alfredo Beltrán-Sierra } \\
\text { T-572-05, } 27 \text { de mayo de 2005, Álvaro Tafur-Galvis } \\
\text { T-577-05, } 27 \text { de mayo de 2005, Humberto Sierra-Porto } \\
\text { T-578-05, } 27 \text { de mayo de 2005, Humberto Sierra-Porto } \\
\text { T-584-05, } 2 \text { de junio de 2005, Alfredo Beltrán-Sierra } \\
\text { T-622-05, } 16 \text { de junio de 2005, Álvaro Tafur-Galvis } \\
\text { T-624-05, } 16 \text { de junio de 2005, Alvaro Tafur-Galvis } \\
\text { T-684-05, } 30 \text { de junio de 2005, Marco Gerardo Monroy- } \\
\text { Cabra } \\
\text { T-743-05, } 14 \text { de julio de 2005, Alfredo Beltrán-Sierra } \\
\text { T-792-05, } 28 \text { de julio de 2005, Clara Inés Vargas- } \\
\text { Hernández } \\
\text { T-848-05, } 16 \text { de agosto de 2005, José Manuel Cepeda- } \\
\text { Espinosa } \\
\text { T-900-05, } 1 \text { de septiembre de 2005, Alfredo Beltrán- } \\
\text { Sierra } \\
\text { T-972-05, } 23 \text { de septiembre de 2005, Jaime Córdoba- } \\
\text { Triviño } \\
\text { T-1084-05, } 27 \text { de octubre de 2005, Alfredo Beltrán-Sierra } \\
\text { T-1093-05, } 26 \text { de octubre de 2005, Clara Inés Vargas- } \\
\text { Hernández } \\
\text { T-1096-05, } 26 \text { de octubre de 2005, Clara Inés Vargas- } \\
\text { Hernández } \\
\text { T-1145-05, } 10 \text { de noviembre de 2005, Rodrigo Escobar-Gil } \\
\text { T-1180-05, } 18 \text { de noviembre de 2005, Jaime Córdoba- } \\
\text { Triviño } \\
\text { T-1221-05, } 25 \text { de noviembre de 2005, Jaime Córdoba- } \\
\text { Triviño } \\
\text { T-1259-05, } 5 \text { de diciembre de 2005, Álvaro Tafur-Galvis } \\
\text { T-1275-05, } 6 \text { de diciembre de 2005, Humberto Antonio } \\
\text { Sierra-Porto } \\
\text { T-1303-05, } 9 \text { de diciembre de 2005, Jaime Córdoba- } \\
\text { Triviño } \\
\text { T-1322-05, } 15 \text { de diciembre de 2005, Manuel José Cepeda- } \\
\text { Espinosa } \\
\text { T-1326-05, } 15 \text { de diciembre de 2005, Humberto Antonio } \\
\text { Sierra-Porto }\end{array}$ \\
\hline
\end{tabular}




\begin{tabular}{|c|c|}
\hline Año & Sentencias \\
\hline 2006 & $\begin{array}{l}\text { T-133-06, } 23 \text { de febrero de 2006, Humberto Antonio } \\
\text { Sierra-Porto } \\
\text { T-291-06, } 6 \text { de abril de 2006, Jaime Araújo-Rentería } \\
\text { T-317-06, } 24 \text { de abril de 2006, Clara Inés Vargas- } \\
\text { Hernández } \\
\text { T-346-06, } 4 \text { de mayo de 2006, Clara Inés Vargas- } \\
\text { Hernández } \\
\text { T-361-06, } 11 \text { de mayo de 2006, Jaime Araújo-Rentería } \\
\text { T-376-06, } 18 \text { de mayo de 2006, Marco Gerardo Monroy- } \\
\text { Cabra } \\
\text { T-439-06, } 1 \text { de junio de 2006, Marco Gerardo Monroy- } \\
\text { Cabra } \\
\text { T-482-06, } 22 \text { de junio de 2006, Álvaro Tafur-Galvis } \\
\text { T-599-06, } 27 \text { de julio de 2006, Álvaro Tafur-Galvis } \\
\text { T-644-06, } 8 \text { de agosto de 2006, Rodrigo Escobar-Gil } \\
\text { T-686-06, } 17 \text { de agosto de 2006, Humberto Antonio } \\
\text { Sierra-Porto } \\
\text { T-695-06, } 22 \text { de agosto de 2006, Jaime Araújo-Rentería } \\
\text { T-711-06, } 22 \text { de agosto de 2006, Rodrigo Escobar-Gil } \\
\text { T-724-06, } 24 \text { de agosto de 2006, Allvaro Tafur-Galvis } \\
\text { T-774-06, 8 de septiembre de 2006, Rodrigo Escobar-Gil } \\
\text { T-795-06, } 21 \text { de septiembre de 2006, Clara Inés Vargas- } \\
\text { Hernández } \\
\text { T-797-06, } 19 \text { de septiembre de 2006, Jaime Córdoba- } \\
\text { Triviño } \\
\text { T-842-06, } 12 \text { de octubre de 2006, Clara Inés Vargas- } \\
\text { Hernández } \\
\text { T-865-06, } 19 \text { de octubre de 2006, Jaime Araújo-Rentería } \\
\text { T-893A-06, } 2 \text { de noviembre de 2006, Álvaro Tafur-Galvis } \\
\text { T-896A-06, } 2 \text { de noviembre de 2006, Marco Gerardo } \\
\text { Monroy-Cabra } \\
\text { T-897A-06, } 2 \text { de noviembre de 2006, Marco Gerardo } \\
\text { Monroy-Cabra } \\
\text { T-957-06, } 17 \text { de noviembre de 2006, Jaime Araújo- } \\
\text { Rentería } \\
\text { T-963-06, } 23 \text { de noviembre de 2006, Clara Inés Vargas- } \\
\text { Hernández } \\
\text { T-966-06, } 23 \text { de noviembre de 2006, Clara Inés Vargas- } \\
\text { Hernández } \\
\text { T-970-06, } 23 \text { de noviembre de 2006, Álvaro Tafur-Galvis } \\
\text { T-1055-06, } 7 \text { de diciembre de 2006, Jaime Araújo- } \\
\text { Rentería } \\
\text { T-1062-06, } 7 \text { de diciembre de 2006, Clara Inés Vargas- } \\
\text { Hernández }\end{array}$ \\
\hline
\end{tabular}




\begin{tabular}{|c|c|}
\hline Año & Sentencias \\
\hline 2007 & $\begin{array}{l}\text { T-048-07, } 1 \text { de febrero de 2007, Clara Inés Vargas- } \\
\text { Hernández } \\
\text { T-161-07, } 8 \text { de marzo de 2007, Jaime Araújo-Rentería } \\
\text { T-232-07, } 29 \text { de marzo de 2007, Jaime Córdoba-Triviño } \\
\text { T-322-07, } 4 \text { de mayo de 2007, Manuel José Cepeda- } \\
\text { Espinosa } \\
\text { T-355-07, } 10 \text { de mayo de 2007, Humberto Antonio Sierra- } \\
\text { Porto } \\
\text { T-356-07, } 10 \text { de mayo de 2007, Humberto Antonio Sierra- } \\
\text { Porto } \\
\text { T-357-07, } 10 \text { de mayo de 2007, Humberto Antonio Sierra- } \\
\text { Porto } \\
\text { T-488-07, } 25 \text { de junio de 2007, Humberto Antonio Sierra- } \\
\text { Porto } \\
\text { T-537-07, } 13 \text { de julio de 2007, Nilson Pinilla-Pinilla } \\
\text { T-566-07, } 27 \text { de julio de 2007, Clara Inés Vargas- } \\
\text { Hernández } \\
\text { T-627-07, } 15 \text { de agosto de 2007, Clara Inés Vargas- } \\
\text { Hernández } \\
\text { T-674-07, } 30 \text { de agosto de 2007, Humberto Antonio } \\
\text { Sierra-Porto } \\
\text { T-693-07, } 6 \text { de septiembre de 2007, Manuel José Cepeda- } \\
\text { Espinosa } \\
\text { T-694-07, } 6 \text { de septiembre de 2007, Manuel José Cepeda- } \\
\text { Espinosa } \\
\text { T-739-07, } 20 \text { de septiembre de 2007, Jaime Córdoba- } \\
\text { Triviño } \\
\text { T-750-07, } 21 \text { de septiembre de 2007, Clara Inés Vargas- } \\
\text { Hernández } \\
\text { T-894-07, } 25 \text { de octubre de 2007, Clara Inés Vargas- } \\
\text { Hernández }\end{array}$ \\
\hline
\end{tabular}




\begin{tabular}{|c|l|}
\hline Año & \multicolumn{1}{|c|}{ Sentencias } \\
\hline 2008 & T-020-08, 22 de enero de 2008, Jaime Araújo-Rentería \\
& T-178-08, 21 de febrero de 2008, Rodrigo Escobar-Gil \\
& T-274-08, 11 de marzo de 2008, Jaime Araújo-Rentería \\
& T-402-08, 25 de abril de 2008, Mauricio González- \\
& Cuervo \\
& T-436-08, 8 de mayo de 2008, Marco Gerardo Monroy- \\
& Cabra \\
& T-515-08, 22 de mayo de 2008, Clara Inés Vargas- \\
& Hernández \\
& T-522-08, 22 de mayo de 2008, Manuel José Cepeda- \\
& Espinosa \\
& T-571-08, 4 de junio de 2008, Humberto Antonio Sierra- \\
& Porto \\
& T-615-08, 23 de junio de 2008, Rodrigo Escobar-Gil \\
& T-635-08, 26 de junio de 2008, Mauricio González- \\
& Cuervo \\
& T-793-08, 19 de agosto de 2008, Humberto Antonio \\
& Sierra-Porto. \\
& T-815-08, 21 de agosto de 2008, Clara Inés Vargas- \\
& Hernández \\
& T-1024-08, 17 de octubre de 2008, Marco Gerardo \\
& Monroy-Cabra \\
& T-1031-08, 17 de octubre de 2008, Mauricio González- \\
& Cuervo \\
& T-1272-08, 18 de diciembre de 2008, Mauricio González- \\
& Cuervo \\
\hline
\end{tabular}




\begin{tabular}{|c|c|}
\hline Año & Sentencias \\
\hline 2009 & $\begin{array}{l}\text { T-061-09, } 5 \text { de febrero de 2009, Marco Gerardo Monroy- } \\
\text { Cabra } \\
\text { T-093-09, } 17 \text { de febrero de 2009, Mauricio González- } \\
\text { Cuervo } \\
\text { T-126-09, } 24 \text { de febrero de 2009, Humberto Antonio } \\
\text { Sierra-Porto } \\
\text { T-185-09, } 19 \text { de marzo de 2009, Juan Carlos Henao-Pérez } \\
\text { T-210-09, } 26 \text { de marzo de 2009, Nilson Pinilla-Pinilla } \\
\text { T-412-09, } 23 \text { de junio de 2009, María Victoria Calle- } \\
\text { Correa } \\
\text { T-435-09, } 2 \text { de julio de 2009, Jorge Ignacio Pretelt- } \\
\text { Chaljub } \\
\text { T-462-09, } 13 \text { de julio de 2009, Mauricio González-Cuervo } \\
\text { T-511-09, } 30 \text { de julio de 2009, Jorge Ignacio Pretelt- } \\
\text { Chaljub } \\
\text { T-527-09, } 5 \text { de agosto de 2009, Nilson Pinilla-Pinilla } \\
\text { T-540-09, } 6 \text { de agosto de 2009, Jorge Ignacio Pretelt- } \\
\text { Chaljub } \\
\text { T-705-09, } 6 \text { de octubre de 2009, Nelson Pinilla-Pinilla } \\
\text { T-744-09, } 19 \text { de octubre de 2009, Gabriel Eduardo } \\
\text { Mendoza-Martelo } \\
\text { T-825-09, } 19 \text { de noviembre de 2009, Luis Ernesto Vargas- } \\
\text { Silva } \\
\text { T-844-09, } 24 \text { de noviembre de 2009, Jorge Ignacio Pretelt- } \\
\text { Chaljub } \\
\text { T-971-09, } 18 \text { de diciembre de 2009, Mauricio González- } \\
\text { Cuervo }\end{array}$ \\
\hline 2010 & $\begin{array}{l}\text { T-023-10, } 26 \text { de enero de 2010, Humberto Antonio Sierra- } \\
\text { Porto } \\
\text { T-139-10, } 24 \text { de febrero de 2010, Mauricio González- } \\
\text { Cuervo } \\
\text { T-190-10, } 18 \text { de marzo de 2010, Jorge Iván Palacio-Palacio } \\
\text { T-193-10, } 23 \text { de marzo de 2010, Nilson Pinilla-Pinilla } \\
\text { T-429-10, } 28 \text { de mayo de 2010, Juan Carlos Henao-Pérez } \\
\text { T-479-10, } 16 \text { de junio de 2010, Juan Carlos Henao-Pérez } \\
\text { T-499-10, } 17 \text { de junio de 2010, Gabriel Eduardo Mendoza- } \\
\text { Martelo } \\
\text { T-545-10, } 30 \text { de junio de 2010, Mauricio González-Cuervo } \\
\text { T-622-10, } 9 \text { de agosto de 2010, Nilson Pinilla-Pinilla } \\
\text { T-690-10, } 2 \text { de septiembre de 2010, Humberto Antonio } \\
\text { Sierra-Porto } \\
\text { T-739-10, } 13 \text { de septiembre de 2010, Mauricio González- } \\
\text { Cuervo } \\
\text { T-804-10, } 7 \text { de octubre de 2010, Juan Carlos Henao-Pérez } \\
\text { T-825-10, } 19 \text { de octubre de 2010, Luis Ernesto Vargas- } \\
\text { Silva }\end{array}$ \\
\hline
\end{tabular}




\begin{tabular}{|c|l|}
\hline Año & \multicolumn{1}{|c|}{ Sentencias } \\
\hline 2011 & T-062-11, 4 de febrero de 2011, Luis Ernesto Vargas-Silva \\
& T-138-11, 4 de marzo de 2011, María Victoria Calle- \\
& Correa \\
& T-161-11, 10 de marzo de 2011, Humberto Antonio Sierra- \\
& Porto \\
& T-265-11, 7 de abril de 2011, Jorge Ignacio Pretelt-Chaljub \\
& T-286-11, 14 de abril de 2011, Jorge Ignacio Pretelt- \\
& Chaljub \\
& T-311-11, 3 de mayo de 2011, Juan Carlos Henao-Pérez \\
& T-319-11, 4 de mayo de 2011, Jorge Iván Palacio-Palacio \\
& T-324-11, 4 de mayo de 2011, Jorge Iván Palacio-Palacio \\
& T-374-11, 11 de mayo de 2011, Jorge Ignacio Pretelt- \\
& Chaljub \\
& T-423-11, 17 de mayo de 2011, Juan Carlos Henao-Pérez \\
& T-669-11, 8 de septiembre de 2011, Humberto Antonio \\
& Sierra-Porto \\
& T-830-11, 2 de noviembre de 2011, Jorge Iván Palacio- \\
& Palacio \\
& T-895-11, 30 de noviembre de 2011, Gabriel Eduardo \\
& Mendoza-Martelo \\
& T-942-11, 15 de diciembre de 2011, Humberto Antonio \\
& Sierra-Porto \\
& T-948-11, 16 de diciembre de 2011, Juan Carlos Henao- \\
& Pérez
\end{tabular}




\begin{tabular}{|c|c|}
\hline Año & $\begin{array}{c}\text { Sentencias } \\
\end{array}$ \\
\hline 2012 & $\begin{array}{l}\text { T-163-12, } 5 \text { de marzo de 2012, Gabriel Eduardo Mendoza- } \\
\text { Martelo } \\
\text { T-175-12, } 8 \text { de marzo de 2012, María Victoria Calle- } \\
\text { Correa } \\
\text { T-232-12, } 20 \text { de marzo de 2012, Gabriel Eduardo } \\
\text { Mendoza-Martelo } \\
\text { T-309-12, } 24 \text { de abril de 2012, Jorge Iván Palacio-Palacio } \\
\text { T-328-12, } 3 \text { de mayo de 2012, María Victoria Calle- } \\
\text { Correa } \\
\text { T-377-12, } 18 \text { de mayo de 2012, María Victoria Calle- } \\
\text { Correa } \\
\text { T-466-12, } 21 \text { de junio de 2012, Jorge Iván Palacio-Palacio } \\
\text { T-474-12, } 25 \text { de junio de 2012, María Victoria Calle- } \\
\text { Correa } \\
\text { T-483-12, } 25 \text { de junio de 2012, Gabriel Eduardo } \\
\text { Mendoza-Martelo } \\
\text { T-669-12, } 24 \text { de agosto de 2012, Gabriel Eduardo } \\
\text { Mendoza-Martelo } \\
\text { T-739-12, } 25 \text { de septiembre de 2012, Nilson Pinilla-Pinilla } \\
\text { T-761-12, 2 de octubre de 2012, Gabriel Eduardo } \\
\text { Mendoza-Martelo } \\
\text { T-764-12, } 2 \text { de octubre de 2012, Jorge Ignacio Pretelt- } \\
\text { Chaljub } \\
\text { T-792A-12, } 11 \text { de octubre de 2012, Alexei Egor Julio- } \\
\text { Estrada } \\
\text { T-865-12, } 25 \text { de octubre de 2012, Alexei Egor Julio- } \\
\text { Estrada } \\
\text { T-954-12, } 20 \text { de noviembre de 2012, Mauricio González- } \\
\text { Cuervo } \\
\text { T-959-12, } 20 \text { de noviembre de 2012, Mauricio González- } \\
\text { Cuervo }\end{array}$ \\
\hline
\end{tabular}

Fuente: elaboración propia

Este no es un panorama ideal, por varias razones: la capacidad de revisión de fallos de tutela por parte de la Corte es limitada, frente al voluminoso número de casos que fallan todos los jueces del país. Se desconoce si, en los casos no revisados por la Corte, los jueces bajo los desarrollos sobre la dignidad amparan los derechos de los accionantes; de otra parte, parece que la cultura jurídica del país desconoce la fuerza vinculante de los precedentes en materia de tutela y sus efectos inter pares. Más aún, si individualizamos el caso de la sentencia T-153-98, mediante la cual la Corte declaró el estado de cosas inconstitucional relativo a la población carcelaria. 
De otra parte, sorprende que en el país el conflicto estructural y evidente del sistema penitenciario no haya sido superado, a pesar de los pronunciamientos judiciales e, incluso, de las declaratorias de estados de emergencia, como la conmoción interior decretada frente a crisis del sistema carcelario por parte de diferentes gobiernos en 1992, 1994 y 1995, algunas de las cuales fueron declaradas inconstitucionales por la Corte; precisamente, por recurrir a un estado excepcional para intentar superar un problema estructural. Y finalmente, asombra que en los presupuestos nacionales desde 1998, fecha en la que la Corte declara el estado de cosas inconstitucional, no se refleje una importante inversión para el mejoramiento de las estructuras físicas, como registramos en la siguiente tabla, ni cambios radicales sobre la política criminal del país, aspecto sobre el cual la Corte Suprema de Justicia ha insistido sin lograr mayores avances ${ }^{46}$.

46 En Colombia no se ha fijado una política criminal clara o precisa, de acuerdo con lo dicho en las sentencias de la Corte Suprema de Justicia. Colombia, Corte Suprema de Justicia, radicado 17108, 2005, magistrado ponente Jorge Luis Quintero-Milanés. Colombia, Corte Suprema de Justicia, radicado 24196, 2005, magistrada ponente Marina Pulido de Barón. Colombia, Corte Suprema de Justicia, radicado 25705, 2006, magistrado ponente Alfredo Gómez-Quintero. Colombia, Corte Suprema de Justicia, radicado 27153, 2007, magistrado ponente Sigifredo Espinosa-Pérez. Colombia, Corte Suprema de Justicia, radicado 27128, 2007, magistrado ponente Mauro Solarte-Portilla. Colombia, Corte Suprema de Justicia, radicado 26945, 2007, magistrados ponentes Yesid Ramírez-Bastidas y Julio Socha-Salamanca. 


\section{Tabla 2}

Presupuesto destinado a las cárceles del país, 19992015

\begin{tabular}{|l|l|l|}
\hline Año & INPEC & Fuente \\
\hline 2015 & $\$ 917.348 .277 .109^{47}$ & Decreto 2710 de 2014 \\
\hline 2014 & $\$ 938.995 .115 .725$ & Decreto 3036 de 2013 \\
\hline 2013 & $\$ 891.264 .671 .119$ & Decreto 2715 de 2012 \\
\hline 2012 & $\$ 1.202 .174 .529 .951$ & Decreto 4970 de 2011 \\
\hline 2011 & $\$ 1.087 .876 .271 .510$ & Decreto 4803 de 2010 \\
\hline 2010 & $\$ 1.009 .364 .822 .282$ & Decreto 4996 de 2009 \\
\hline 2009 & $\$ 765.670 .877 .849$ & Decreto 4841 de 2008 \\
\hline 2008 & $\$ 666.465 .116 .071$ & Decreto 4994 de 2007 \\
\hline 2007 & $\$ 667.652 .250 .349$ & Decreto 4579 de 2006 \\
\hline 2006 & $\$ 612.854 .650 .074$ & Decreto 4731 de 2005 \\
\hline 2005 & $\$ 531.127 .225 .998$ & Decreto 4365 de 2004 \\
\hline 2004 & $\$ 418.320 .809 .366$ & Decreto 3787 de 2003 \\
\hline 2003 & $\$ 352.063 .478 .134$ & Decreto 3200 de 2002 \\
\hline 2002 & $\$ 335.912 .494 .642$ & Decreto 2288 de 2001 \\
\hline 2001 & $\$ 306.662 .856 .561$ & Decreto 2790 de 2000 \\
\hline 2000 & $\$ 271.181 .394 .063$ & Ley 547 de 1999 \\
\hline 1999 & $\$ 293.032 .619 .615$ & Decreto 2354 de 1998 \\
\hline
\end{tabular}

47 En 2015, se destinaron \$779.180.109.539 para la Unidad de Servicios Penitenciarios y Carcelarios, USPEC. 


\section{LOS CENTROS DE RECLUSIÓN}

De otra parte, al revisar la categoría determinada para el análisis que se refiere a las zonas del país desde donde se presentó el mayor número de solicitudes de protección, Bogotá ${ }^{48}$, capital de Colombia, registra la mayor cantidad de casos de vulneración a los derechos de la población carcelaria; de manera específica, la Penitenciaría Central La Picota se ubica como el centro penitenciario donde más casos se han tutelado, seguido muy de cerca por la Cárcel Nacional La Modelo ${ }^{49}$.

En la Sentencia T-577-0550, del magistrado ponente Humberto Antonio Sierra-Porto - que se refiere a la Cárcel Modelo, cuya población en 2013 ascendía a 5.039 y tenía una capacidad real de $2.907^{51}$ — la Corte consideró que la exclusión y confinamiento casi absoluto de los reclusos portadores del VIH/sida transgredía los derechos a la igualdad y dignidad humana, entre otros ${ }^{52}$.

48 De las sentencias analizadas, en 11 casos (T-153-98, T-349-98, T-490-98, T-583-98, T-144-00, T-233-01, T-495-01, T-1025-03, T-577-05, T-578-05, T-388-13), el accionado era el director o un funcionario de una de las cárceles ubicadas en Bogotá, siendo la ciudad que más casos reportó

49 En una de las sentencias relevantes expedidas por la Corte, de la que hicimos alusión en la introducción de esta investigación, se incluye la Cárcel Modelo de Bogotá, como uno de los centros penitenciarios que de manera urgente y necesaria requieren la intervención del Estado para superar las condiciones indignas en las que vive la población carcelaria. Se trata de la sentencia T-388/13 que da cuenta de órdenes dirigidas a mejorar las condiciones de seis centros penitenciarios del país: Complejo Carcelario y Penitenciario Metropolitano de Cúcuta, COCUC; Cárcel La Tramacúa de Valledupar; Cárcel Modelo de Bogotá; Cárcel Nacional Bellavista de Medellín; Cárcel San Isidro de Popayán; Establecimiento Penitenciario y Carcelario de Barrancabermeja. Además, conviene señalar que en 2013, las cárceles en Bogotá estaban en las siguientes condiciones: Complejo Carcelario y Penitenciario Metropolitano de Bogotá (La Picota) con capacidad para 4.931 personas tenía 7.848 reclusos; la Reclusión de Mujeres, Pabellón de Alta Seguridad, Establecimiento de Reclusión Especial, RM PAS ERE Bogotá (de la Cárcel del Buen Pastor) con capacidad para 1.275 tenía 1.961 personas; y el Establecimiento Carcelario, EC Bogotá (La Modelo) con capacidad para 2.907 tenía 4.874 reclusos. El Tiempo, Cárceles y presos de Colombia. El país detrás de las rejas. La precaria situación de las cárceles, El Tiempo (octubre de 2014). Disponible en: http://www.eltiempo. com/multimedia/infografias/carceles-y-presos-de-colombia/14739475

50 El accionante interpone una tutela contra la Cárcel del Distrito Judicial la Modelo de Bogotá, debido a que tiene VIH y por ello, estaba recluido exclusivamente en el patio Nuevo Milenio de la prisión, impidiéndosele trasladarse a otros sitios dentro de la cárcel, situación que le impedía asistir a talleres y capacitaciones dictadas por fuera de ese patio, lo cual configura la vulneración a la dignidad humana y la igualdad.

51 El Tiempo, Cárceles y presos de Colombia. El país detrás de las rejas. La precaria situación de las cárceles, El Tiempo (octubre de 2014). Disponible en: http://www.eltiempo.com/multimedia/ infografias/carceles-y-presos-de-colombia/14739475

52 Colombia, Corte Constitucional, Sentencia T-577-05, 27 de mayo de 2005, magistrado ponente Humberto Sierra-Porto. Disponible en: http://www.corteconstitucional.gov.co/ relatoria/2005/t-577-05.htm 
De otra parte, se presentaron nueve revisiones ${ }^{53}$ contra cárceles de la ciudad de Medellín. En esta ciudad, encontramos que el Instituto Nacional Penitenciario (Establecimiento Penitenciario de Mediana Seguridad y Carcelario, antes Cárcel Bellavista, EPMSC) de Medellín tenía capacidad para 2.424 reclusos en 2013; sin embargo, albergaba 5.741, y el Complejo Penitenciario Pedregal Reclusión de Mujeres, RM, con capacidad para 2.445 personas, tenía para el mismo período 3.098 internas $^{54}$. Con igual tendencia, encontramos cinco casos en la ciudad de Cúcuta ${ }^{55}$ que en 2013 arrojaba una capacidad del Complejo Metropolitano de 2.530 internos, pero albergaba a $4.377^{56}$.

De los datos generales encontrados en el análisis de jurisprudencia, se concluye que en los centros penitenciarios accionados no es posible un proceso de resocialización de la población carcelaria en condiciones de dignidad.

\section{LOS DERECHOS VIOLADOS}

Sobre los derechos vulnerados a la población carcelaria en los centros penitenciarios, todos afectan la dignidad humana. En razón a esta vulneración, se hacen evidentes violaciones a varios derechos como la vida; la libertad, entendiendo por ella la negación del recurso de habeas corpus; la igualdad y la prohibición de la discriminación; el derecho a no ser sometido a torturas, tratos crueles, degradantes e inhumanos; la libertad de pensamiento, conciencia, expresión y opinión; el derecho a la libertad de reunión y asociación pacífica y el derecho a la libertad religiosa, entre otros.

El mayor número de pronunciamientos ${ }^{57}$ se da frente al derecho a la vida, razón por la cual la Corte ha insistido en que permanece

53 T-473-95, T-555-95, T-317-97, T-153-98, T-946-99, T-256-00, T-257-00, T-979-00, T-728-01, T-38813.

54 El Tiempo, Cárceles y presos de Colombia. El país detrás de las rejas. La precaria situación de las cárceles, El Tiempo (octubre de 2014). Disponible en: http://www.eltiempo.com/multimedia/ infografias/carceles-y-presos-de-colombia/14739475

55 T-388-93, T-490-98, T-606-98, T-607-98, T-358-01, T-388-13.

56 El Tiempo, Cárceles y presos de Colombia. El país detrás de las rejas. La precaria situación de las cárceles, El Tiempo (octubre de 2014). Disponible en: http://www.eltiempo.com/multimedia/ infografias/carceles-y-presos-de-colombia/14739475

57 Son 55 pronunciamientos sobre el derecho a la vida: T-494-93, T-235-94, T-277-94, T-502-94, T-247-96, T-680-96, T-342-97, T-279-98, T-583-98, T-590-98, T-208-99, T-265-99, T-524-99, T-415-00, T-607-00, T-611-00, T-1499-00, T-1518-00, T-1606-00, T-1739-00, T-233-01, T-495- 
incólume y, en este sentido, es igual al de las personas que están en libertad, con el mismo contenido, las mismas garantías y sin ningún tipo de limitaciones; más aún si se atiende a la circunstancia de que la población carcelaria, por ser excluida socialmente, adquiere durante el término de su reclusión, la condición de sujeto de especial protección constitucional. Al respecto, se destacan tres casos: la sentencia T-680-9658, en la que se establece: "La restricción de ciertos derechos del detenido o condenado, no implica que el Estado omita el deber constitucional de proteger su vida y su integridad física" 59 (negrillas fuera del texto). En los mismos términos, la Corte se manifiesta en la sentencia T-247-96 ${ }^{60}$, en la que estima que el Estado asume la responsabilidad de salvaguardar la vida, seguridad e integridad física de las personas desde la privación de la libertad y durante el traslado a los sitios en donde se cumplirá la pena o se haya impuesto la medida cautelar privativa de la libertad ${ }^{61}$. Finalmente, en la sentencia T-966-0062, la Corte reconoce la existencia de derechos absolutamente limitados a partir de la captura (libertad personal o libre locomoción), otros fuertemente limitados

01, T-521-01, T-728-01, T-944-01, T-1077-01, T-169-02, T-269-02, T-461-02, T-698-02, T-839-02, T-881-02, T-958-02, T-1006-02, T-085-03, T-172-03, T-545-03, T-638-03, T-703-03, T-1174-03, T-1206-03, T-639-04, T-860-04, T-1096-04, T-1239-04, T-052-05, T-254-05, T-507-05, T-622-05, T-743-05, T-900-05, T-1013-05, T-1180-05, T-077-13, T-266-13.

58 El accionante interpuso una acción de tutela contra el director de la Cárcel de la Policía Nacional de Facatativá, debido a que fue recluido en la cárcel La Modelo de Bogotá por causa de una detención preventiva, sin tener en cuenta que pertenecía a la Policía Nacional. Por este hecho, le solicitó al accionado que lo traspasara a esa cárcel y recibió como respuesta que estaba demasiado hacinada para poder tenerlo a él. Esta respuesta vulneraba el derecho a la vida e integridad física del accionante.

59 Colombia, Corte Constitucional, Sentencia T-680-96, 4 de diciembre de 1996, magistrado ponente Carlos Gaviria-Díaz. Disponible en: http://corteconstitucional.gov.co/ relatoria/1996/t-680-96.htm

60 La accionante interpuso una acción de tutela contra el director de la Cárcel de la Policía Nacional de Facatativá, en calidad de madre de una persona detenida en las instalaciones de la cárcel La Modelo de Bogotá. Su hijo pertenecía a la Policía Nacional y solicitó ser recluido en la cárcel que dirige el accionado; sin embargo, este se negó a recibirlo, por lo que vulneró los derechos a la vida e integridad física del hijo de la accionante.

61 Colombia, Corte Constitucional, Sentencia T-680-96, 4 de diciembre de 1996, magistrado ponente Carlos Gaviria-Díaz. Disponible en: http://corteconstitucional.gov.co/ relatoria/1996/t-680-96.htm

62 Los accionantes interpusieron acción de tutela contra la directora y el comandante de vigilancia de la Cárcel del Distrito Judicial de Cali Villahermosa, puesto que en varias ocasiones habían solicitado su traslado a las audiencias penales que se adelantan en su contra, y ellos no se lo habían permitido arguyendo que no había personal ni capacidad para transportarlos. Esta conducta vulneraba los derechos a la igualdad, libertad, debido proceso y defensa de los accionados. 
(intimidad, libertad de reunión) y otros que no pueden ser objeto de restricción, como la vida o la integridad persona $1^{63}$.

De otra parte, en cuanto al derecho a la libertad, la Corte realiza un amplio desarrollo en el que comprende diferentes esferas sobre este derecho durante los períodos de reclusión, cobijando la etapa de investigación, frente a la cual advierte la necesaria observación por parte de los fiscales de las reglas sobre privación de la libertad en cuanto a la oportunidad y proporcionalidad del establecimiento de restricciones, pasando por las garantías frente a la interposición de habeas corpus y el otorgamiento de libertad, ante la ejecución de la pena sin restricciones o alusión a trámites burocráticos para su declaración. En este sentido, la sentencia T-361-9764 determina:

Ya que los fiscales deben orientar su actuación oficial al logro de los fines consignados en el artículo 2 Superior - 'proteger a todas las personas residentes en Colombia, en su vida, honra, bienes, creencias, y demás derechos y libertades, y para asegurar el cumplimiento de los deberes sociales del Estado y de los particulares'-, es apenas elemental que se les exija identificar a la persona cuyos derechos y garantías afectan al ordenar su vinculación a un proceso penal ${ }^{65}$.

Sobre el habeas corpus, la Sentencia C-620-0166 determina que, además de ser un derecho fundamental, se trata de la acción tutelar de la libertad ${ }^{67}$; de igual forma, la Sentencia T-724-06 establece la

63 Colombia, Corte Constitucional, Sentencia T-966-00, 31 de julio de 2000, magistrado ponente Eduardo Cifuentes-Muñoz. Disponible en: http://www.corteconstitucional.gov.co/ relatoria/2000/t-966-00.htm

$64 \mathrm{El}$ accionante fue sindicado de la comisión de un delito, junto a otras personas, que fueron capturadas y contra quienes se decretó medida de aseguramiento de detención preventiva sin beneficio de excarcelación. En su caso, fue emplazado, se declaró como persona ausente, se le concedió un defensor de oficio y se terminó decretando la misma medida que a los demás, por lo que se libró orden de captura en su contra. Por lo anterior, el accionante interpuso acción de tutela contra la Fiscalía Regional de Antioquia, pues consideró que se violaba su derecho a la igualdad y debido proceso, al no ser oído en indagatoria, por lo que no pudo aclarar que su cédula había sido hurtada, por lo cual pudo aparecer en el lugar de los hechos y que no había participado de la comisión de conducta punible alguna.

65 Colombia, Corte Constitucional, Sentencia T-361-97, 5 de agosto de 1997, magistrado ponente Carlos Gaviria-Díaz. Disponible en: http://www.corteconstitucional.gov.co/ relatoria/1997/t-361-97.htm

66 La accionante demandó como inconstitucionales los artículos 9, 144, 203, 354 inciso 1, 382, 383, $384,385,386,387,388,389,392$ parcial, 404 parcial de la Ley 600 de 2000, por vulnerar el non bis in idem, derecho de habeas corpus, derecho a la igualdad y las funciones constitucionales de la Fiscalía. Colombia, Ley 600 de 2000, por la cual se expide el Código de Procedimiento Penal, 44.097 Diario Oficial, 24 de julio de 2000. Disponible en: http://www.secretariasenado. gov.co/senado/basedoc/ley_0600_2000.html

67 Colombia, Corte Constitucional, Sentencia C-620-01, 13 de junio de 2001, magistrado ponente Jaime Araújo-Rentería. Disponible en: http://www.corteconstitucional.gov.co/ 
procedencia del habeas corpus cuando la aprehensión es contraria al artículo 28 de la Constitución Política y cuando la privación de la libertad es ilegal, arbitraria o se ha prolongado indebidamente, pues las limitaciones al derecho a la libertad deben estar regidas por razonabilidad y proporcionalidad ${ }^{68}$.

Frente al derecho a la igualdad y la prohibición de la discriminación, se presentan graves violaciones en razón a la identidad sexual de los sujetos, sus creencias religiosas e, incluso, debidas al conflicto estructural que se vive en el país, por lo que se registran actos discriminatorios de acuerdo al grupo ilegal al que pertenecen los reclusos. Sobre este tema, en la sentencia T-273-93 ${ }^{69}$, una interna en el Centro de Reclusión Femenina El Buen Pastor fue sometida a trato discriminatorio por no poder concebir durante la reclusión ${ }^{70}$. También se tuteló el derecho a la no discriminación en la sentencia $\mathrm{T}-062-11^{71}$, en la que se determinó que el Estado tiene la obligación de garantizar a las minorías, por razones de diversidad de identidad u opción sexual, su derecho a no ser objeto de sanciones o vejaciones, en razón de ello para salvaguardar la dignidad humana y otros derechos ${ }^{72}$.

Frente a esta situación, merece especial atención la sentencia T-314-11 ${ }^{73}$, la cual protegió a la población transgénero recluida en

relatoria/2001/c-620-01.htm

68 Colombia, Corte Constitucional, Sentencia T-724-06, 24 de agosto de 2006, magistrado ponente Álvaro Tafur-Galvis. Disponible en: http://www.corteconstitucional.gov.co/ relatoria/2006/t-724-06.htm

$69 \mathrm{La}$ accionante interpuso una tutela contra la Dirección General de Prisiones y el Centro de Reclusión Femenina El Buen Pastor, debido a que cuando fue a solicitar la visita conyugal, se encontró con una serie de requisitos para obtener este beneficio, los cuales no eran requeridos en las cárceles masculinas, lo que constituía una discriminación injustificada contra la mujer.

70 Colombia, Corte Constitucional, Sentencia T-273-93, 14 de julio de 1993, magistrado ponente Carlos Gaviria-Díaz. Disponible en: http://www.corteconstitucional.gov.co/ relatoria/1993/t-273-93.htm

71 La accionante interpuso acción de tutela contra el Establecimiento Penitenciario de Mediana Seguridad de Yopal (Casanare), debido a que manifestó ser gay transexual y por ello, quería portar cabello largo y accesorios acordes con su identidad de género; sin embargo, el personal de la cárcel se burlaba de él por su condición, le decomisó su kit de maquillaje e incluso la amenazó con que se le iba a cortar el cabello. Por lo anterior, se vulneraban sus derechos a la igualdad, a no ser discriminado y al libre desarrollo de la personalidad.

72 Colombia, Corte Constitucional, Sentencia T-062-11, 4 de febrero de 2011, magistrado ponente Luis Ernesto Vargas-Silva. Disponible en: http://www.corteconstitucional.gov.co/ relatoria/2011/t-062-11.htm

73 La accionante interpuso acción de tutela contra Olga María Chacón, Carlos Dávila y la sociedad Hotelera Tequendama S.A., pues por ser mujer trans se le negó la entrada a un evento público para el cual había comprado boletas. En el marco del proceso, la Corte Constitucional encontró demostrado que había otros espacios en que también se desconocían los derechos a la 
centros carcelarios. En Colombia, el principio fundamental del pluralismo se observa, entre otras esferas, en la protección a las personas trans (transgénero, transexuales y travestis) ${ }^{74}$.

De otra parte, frente al derecho a no ser sometido a torturas, tratos crueles, degradantes e inhumanos, la Corte indica que la privación de la libertad no tiene un sentido de retaliación social o de venganza, ni puede ser aplicada con resentimiento y mucho menos con desprecio hacia el ser humano al que se le ha impuesto ${ }^{75}$. La Sentencia T-153-98 ${ }^{76}$ se indica que los derechos "tales como la vida e integridad personal, la dignidad, la igualdad, la libertad religiosa, el derecho al reconocimiento de la personalidad jurídica, a la salud y al debido proceso, y el derecho de petición, mantienen su incolumidad a pesar del encierro a que es sometido su titular"77.

Y en sentencia T-702- $01^{78}$ se concluye que:

igualdad y libre desarrollo de la personalidad de las personas transgénero, como los espacios carcelarios. Colombia, Corte Constitucional, Sentencia T-314-11, 4 de mayo de 2011, magistrado ponente Jorge Iván Palacio-Palacio. Disponible en: http://www.corteconstitucional.gov.co/ relatoria/2011/t-314-11.htm

74 Por esta circunstancia, la Corte ha protegido a las personas trans por medio de sentencias como la T-771-13, T-063-15, entre otras, donde ha reivindicado que las mujeres trans no presten el servicio militar puesto que son mujeres, la posibilidad de cambiarse el nombre con ocasión del reconocimiento de su identidad; y el cambio más reciente, la posibilidad de cambiar el componente sexo de su estado civil, lo que también se concretó en el Decreto 1227 de 2015.

75 Juan J. Bustos-Ramírez \& Hernán Hormazábal-Malarée, Lecciones de derecho penal, Volumen I, 46-47 (Trotta, Madrid, 1997). De acuerdo con Bustos y Hormazábal, la teoría retributiva de la pena permite que esta sea proporcional con el mal causado; sin embargo, si esta solo consiste en un mal se asocia con la idea de venganza, la cual no es compatible con el concepto de dignidad humana. Luigi Ferrajoli, El derecho penal mínimo, 0 Poder y Control, 25-48, 38 (1986). Luigi Ferrajoli, Derecho y razón. Teoría del garantismo penal, 333-335 ( $9^{a} \mathrm{ed}$. ., Trotta, Madrid, 2009). Eugenio Raúl Zaffaroni, Alejandro Alagia \& Alejandro Slokar, Derecho penal, parte general, 361 ( $2^{\mathrm{a}}$ ed., Ediar Sociedad Anónima Editora, Comercial, Industrial y Financiera, Buenos Aires, 2002). Incluso, autores como Ferrajoli estiman que el derecho penal, dentro de su función garantista, busca prevenir las manifestaciones de la venganza, pues el poder punitivo/derecho penal debe estar del lado del más débil: la víctima frente al delincuente y del delincuente ante la venganza.

76 Colombia, Corte Constitucional, Sentencia T-153-98, 28 de abril de 1998, magistrado ponente Eduardo Cifuentes-Muñoz. Disponible en: http://www.corteconstitucional.gov.co/ relatoria/1998/t-153-98.htm. La Corte Constitucional reúne varios expedientes de acciones de tutela realizadas contra centros penitenciarios del país, donde la grave situación de hacinamiento y deficiencias en el servicio, se ajustan al concepto estado de cosas inconstitucional, teniendo en cuenta que han ocasionado graves y evidentes vulneraciones a derechos fundamentales como la dignidad humana, vida, integridad personal, familia, salud, trabajo y presunción de inocencia.

77 Colombia, Corte Constitucional, Sentencia T-153-98, 28 de abril de 1998, magistrado ponente Eduardo Cifuentes-Muñoz. Disponible en: http://www.corteconstitucional.gov.co/ relatoria/1998/t-153-98.htm

78 El accionante interpuso acción de tutela contra la Penitenciaría Nacional de Valledupar, puesto que en la cárcel hacían numerosas requisas rutinarias, en las cuales los desnudaban y ponían en posiciones humillantes, por lo que consideraba que se vulneraba su derecho a la 
En el campo especifico de la dignidad de las personas privadas de la libertad, las normas tanto del Pacto Internacional de Derechos Civiles y Políticos, como de la Convención Americana de Derechos Humanos, establecen expresamente que toda persona privada de la libertad deberá recibir un trato que respete la dignidad inherente al ser humano ${ }^{79}$.

Sobre el desarrollo jurisprudencial del derecho a la libertad de pensamiento, conciencia, expresión y opinión, no hay distinciones entre el ejercicio de estas libertades por parte de las personas libres y de la población carcelaria, atendiendo a los instrumentos internacionales que impiden su restricción, salvo las restricciones previstas por la ley, siempre que sean razonables y respeten su núcleo esencial como se describe en la sentencia T-219-93. De otra parte, el derecho a la libertad de reunión y asociación pacífica aparece protegido por la jurisprudencia constitucional, ya que se hace efectivo mediante la conformación de comités que organicen los reclusos y, sobre el cual, la Corte llama la atención a las entidades administradoras de los centros de reclusión, como establece la sentencia T-219-93, en la que la Corte estableció que no se pueden poner trabas a los internos para formar parte del Comité de Derechos Humanos pues ni la Dirección de Cárceles ni el director del establecimiento pueden prohibir la existencia de estos comités, ya que no están habilitados para restringir el derecho a la libertad de expresión ni de reunión ${ }^{80}$. Finalmente, sobre el derecho a la libertad religiosa, la Corte reitera su posición en la sentencia T-376-06, en la que señala que dado el carácter fundamental de esta libertad "en los centros penitenciarios y carcelarios, las autoridades deben adoptar las medidas necesarias y adecuadas a esa finalidad, sin perjuicio de la seguridad de los establecimientos" $"$.

Finalmente, entre los extensos pronunciamientos de la Corte sobre población carcelaria en los últimos veinte años (220), también

dignidad humana. Además, dentro de las mismas instalaciones, los trasladaban esposados.

79 Colombia, Corte Constitucional, Sentencia T-702-01, 5 de julio de 2001, magistrado ponente Marco Gerardo Monroy-Cabra. Disponible en: http://www.corteconstitucional.gov.co/ relatoria/2001/t-702-01.htm

80 Colombia, Corte Constitucional, Sentencia T-219-93, 9 de junio de 1993, magistrado ponente Antonio Barrera-Carbonell. Disponible en: http://www.corteconstitucional.gov.co/ relatoria/1993/t-219-93.htm

81 Colombia, Corte Constitucional, Sentencia T-376-06, 18 de mayo de 2006, magistrado ponente Marco Gerardo Monroy-Cabra. Disponible en: http://www.corteconstitucional.gov.co/ relatoria/2006/t-376-06.htm 
hay casos recurrentes en los que la Corte concede la tutela solicitada por violaciones a la protección de la libertad provisional y condicional frente a vías de hecho ${ }^{82}$, derivadas de las demoras injustificadas por parte de funcionarios judiciales en el trámite de procesos o la concesión de libertad provisional y condicional.

En estas decisiones judiciales, la Corte recuerda a los operadores judiciales el respeto al debido proceso y principio de legalidad como pilares del derecho penal y la protección a la libertad personal por violación del habeas data $^{83}$, en virtud de la cual la desactualización de los sistemas de información de las entidades públicas ha permitido que se ejecuten órdenes de captura no vigentes o se adelanten investigaciones con base en errores originados en homonimia, lo cual configura violaciones a los derechos al buen nombre, honra, intimidad y libertad, entre otros.

82 T-362-02, T-668-02, T-894-02, T-895-02, T-493-03, T-455-04, T-684-04, T-723-06, T-808-06, T-434-07, T-393-08, T-436-08, T-1043-08, T-395-10, T-888-10.

83 T-575-93, T-310-03, T-578-10. 


\section{CONCLUSIONES}

La situación de la población carcelaria en Colombia es denigrante. Basta revisar el alto índice de hacinamiento carcelario para afirmar que la dignidad humana como valor fundamental del Estado Constitucional, se ve constantemente vulnerada en los centros carcelarios del país. De esta situación sobrevienen graves violaciones a diversos derechos fundamentales de los reclusos, que en principio deberían ser protegidos, atendiendo a la condición de sujetos de especial protección constitucional que les asiste en su calidad de personas recluidas en centros carcelarios.

En este escenario, resalta el papel que ha venido desarrollando la Corte Constitucional con la revisión de alrededor de 220 fallos de tutela, los cuales evidencian la falta de garantías primarias que el ejecutivo y el legislador debían otorgar, lo cual convierte al juez constitucional en el actor por medio del cual las personas vulneradas buscan su protección. A pesar del establecimiento de importantes precedentes sobre el tema, la protección judicial ha sido ineficaz; de ello dan cuenta tres importantes sentencias: T-153-98, T-388-13 y T-208-15 en razón a que señalan como dantesca la situación carcelaria. En la primera es evidente que las órdenes judiciales que de ella derivaron no fueron ejecutadas, lo que dio lugar a la expedición (quince años más tarde) de una nueva decisión judicial que creemos más cauta y ponderada, en razón a que establece plazos para el cumplimiento de las órdenes en un intento de evitar lo acontecido en el primer caso: la expedición de una sentencia declarativa con muy pocos efectos.

Del análisis específico de las sentencias revisadas, se concluye que la Corte ha desarrollado un proceso argumentativo sólido al recurrir insistentemente a la dignidad humana, entendida como el valor intrínseco de cada persona por el hecho de ser persona; sin embargo, parece que esta conceptualización es meramente retórica y que los reclusos están condenados al olvido, a la tortura y a los malos tratos por parte del Estado que, por el contrario, debe ser garante de sus derechos.

Podemos concluir que los derechos existen y que, por vía jurisprudencial, se ha determinado su alcance y contenido; sin embargo, hay un puente levadizo que genera un foso en el que se ahogan las 
súplicas de los internos, por falta de una política criminal clara, la asignación de recursos para el mejoramiento de la estructura física de los centros carcelarios y la indolencia del Estado y de la población que siguen asumiendo la pena privativa de la libertad como una retribución o venganza y no como un mecanismo de resocialización; en cuanto a las zonas del país donde más vulneraciones hay, el rastreo realizado no es claro; no obstante, la zona del país de la que se realizaron el mayor número de revisiones es Bogotá, lo que podría relacionarse con que los centros carcelarios de esta ciudad albergan el mayor número de reclusos.

Finalmente, resulta relevante observar cómo desde la jurisprudencia de la $\mathrm{CIDH}$, que en virtud del control de convencionalidad difuso se convierte en una fuente de interpretación obligatoria para los jueces de tutela del país, se han establecido precedentes relevantes sobre la protección carcelaria, amparada en el valor principio - regla de la dignidad humana; sin embargo, la situación de las cárceles del país sigue en una especie de ostracismo que daría lugar a afirmar que, para el Estado, la población carcelaria es una población de segunda que no merece especial protección. 


\section{BIBLIOGRAFÍA}

\section{Libros}

Agamben, Giorgio, Lo que queda de Auschwitz. El archivo y el testigo. Homo Sacer III (Pre-Textos, Valencia, 2009).

Alexy, Robert, Teoría de los derechos fundamentales (Centro de Estudios Políticos y Constitucionales, CEPC, Madrid, 2001).

Barroso, Luis Roberto, La dignidad de la persona humana en el derecho constitucional contemporáneo. La construcción de un concepto jurídico a la luz de la jurisprudencia mundial (Simone Nevares, trad., Universidad del Externado, Bogotá, 2014).

Bustos-Ramírez, Juan J. \& Hormazábal-Malarée, Hernán, Lecciones de derecho penal, Volumen I (Trotta, Madrid, 1997).

Carvajal-Sánchez, Bernardo, El principio de la dignidad de la persona humana en la jurisprudencia constitucional colombiana y francesa (Universidad Externado de Colombia, Instituto de Estudios Constitucionales Carlos Restrepo Piedrahita, ICRP, Bogotá, 2005).

Ferrajoli, Luigi, Democracia y garantismo (Trotta, Madrid, 2008).

Ferrajoli, Luigi, Derecho y razón. Teoría del garantismo penal ( $9^{\mathrm{a}}$ ed., Trotta, Madrid, 2009).

Garland, David, La cultura del control. Crimen y orden social en la sociedad contemporánea (MÁxımo Sozzo, trad., Gedisa, Barcelona, 2005).

Iturralde-Sánchez, Manuel Alejandro \& Ariza-Higuera, Libardo José, Los muros de la infamia: prisiones en Colombia y América Latina (Uniandes, Bogotá, 2011).

Kantorowitz, ERnst H., Los dos cuerpos del rey: un estudio de teología política medieval (Akal, Madrid, 2012).

Molinares, Viridiana, La zona gris, imposibilidad de juicios y una nueva ética (Ediciones Uninorte, Barranquilla, 2012).

Sandoval-Huertas, Emiro, Penología, partes general y especial (Ediciones Jurídicas Gustavo Ibáñez, Bogotá, 1996).

Zaffaroni, Eugenio Raúl; Alagia, Alejandro \& Slokar, Alejandro, Derecho penal, parte general ( $2^{\mathrm{a}}$ ed., Ediar Sociedad Anónima Editora, Comercial, Industrial y Financiera, Buenos Aires, 2002).

\section{Contribuciones en obras colectivas}

Gaviria-Díaz, CArlos, Igualdad, libertad y justicia, en Filosofía del derecho: ética, cultura y Constitución, 431-446 (Miguel Rujana-Quintero, comp., Bogotá, Ediciones Jurídicas Ibáñez, 1999).

Molinares, Viridiana, Control judicial de constitucionalidad: de la crítica sobre su legitimidad democrática a la construcción de nuevas formas de democracia deliberativa, en Debates contemporáneos sobre el derecho público en Colombia, 
84-110 (Uninorte, Barranquilla, 2015).

\section{Revistas}

Ferrajoli, Luigi, El derecho penal mínimo, 0 Poder y Control, 25-48 (1986).

García-González, Aristeo, La dignidad humana: núcleo duro de los derechos humanos, 28 Revista Ius, Universidad Latina de América, UNLA (2008). Disponible en: http://www.unla.mx/iusunla28/, http://www.unla.mx/iusunla28/reflexion/La\%20 Dignidad\%20Humana.htm

Insignares, Silvana \& Molinares, Viridiana, La dignidad humana: incorporación de la jurisprudencia del Tribunal Europeo de Derechos Humanos por la Corte Constitucional Colombiana, 36 Revista de Derecho de la Universidad del Norte, 184-221 (2011). Disponible en: http://rcientificas.uninorte.edu.co/index.php/ derecho/article/view/1900/2221

Martínez-Sánchez, Mauricio, Populismo punitivo, mayorías y víctimas, 2 Nomos, Revista de Derechos Fundamentales, Universidad de Viña del Mar, 183-199 (2008). Disponible en: http://www.derechosfundamentales.cl/revista/02.183-199. Martinez.pdf

\section{Tratados internacionales}

Organización de Estados Americanos, OEA, Convención Americana de Derechos Humanos, Pacto de San José, San José, Costa Rica, 7 al 22 de noviembre de 1969. Disponible en: http://www.oas.org/dil/esp/tratados_B-32_Convencion_ Americana_sobre_Derechos_Humanos.htm

Organización de Estados Americanos, OEA, Convención Interamericana para Prevenir, Sancionar y Erradicar la Violencia contra la Mujer, Convención de Belem Do Pará, Brasil, 9 de junio de 1994. Disponible en: http://oas.org/juridico/spanish/ tratados/a-61.html

Organización de las Naciones Unidas, ONU, Declaración Universal de los Derechos Humanos, Asamblea General, resolución 217 A (III), París, 10 de diciembre de 1948. Disponible en: http://www.un.org/es/documents/udhr/

Organización de las Naciones Unidas, ONU, Pacto Internacional de Derechos Civiles y Políticos, Asamblea General, Resolución 2200 A (XXI), 16 de diciembre de 1966, Disponible en: http://www.ohchr.org/SP/ProfessionalInterest/Pages/CCPR.aspx

\section{Normatividad internacional}

República Federal de Alemania, Ley Fundamental de la República Federal de Alemania, 23 de mayo de 1949. Disponible en: http://ocw.um.es/cc.-juridicas/ derecho-internacional-publico-1/ejercicios-proyectos-y-casos-1/capitulo4/ documento-20-constitucion-de-alemania.pdf, http://www.wipo.int/wipolex/es/ details.jsp?id=9482 
República Italiana, Constitución, 1 de enero de 1948. Disponible en: http://www.ces. es/TRESMED/docum/ita-cttn-esp.pdf, http://www.quirinale.it/qrnw/statico/ costituzione/costituzione.htm

\section{Normatividad colombiana}

Colombia, Acto Legislativo 003 de 2002, por el cual se reforma la Constitución Nacional, 45.040 Diario Oficial, 20 de diciembre de 2002. Disponible en: http://www. secretariasenado.gov.co/senado/basedoc/acto_legislativo_03_2002.html

Colombia, Constitución Política, segunda edición corregida, 116 Gaceta Constitucional, 20 de julio de 1991. Disponible en: http://www.secretariasenado.gov.co/senado/ basedoc/constitucion_politica_1991.html

Colombia, Decreto 1227 de 2015, por el cual se adiciona una sección al Decreto número 1069 de 2015, Único Reglamentario del Sector Justicia y del Derecho, relacionada con el trámite para corregir el componente sexo en el Registro del Estado Civil, 49.532 Diario Oficial, 4 de junio de 2015. Disponible en: https://www.ramajudicial. gov.co/documents/573203/887555/Decreto $+1227+\mathrm{de}+2015+\% 28 \mathrm{Tr} \% \mathrm{C} 3 \% \mathrm{~A} 1 \mathrm{mite}$ +para+corregir+el+componente+sexo+en+el+Registro+del+Estado+Civil $\% 29$. pdf/2eb80ef4-d277-49be-b748-f1112e7852b9

Colombia, Ley 600 de 2000, por la cual se expide el Código de Procedimiento Penal, 44.097 Diario Oficial, 24 de julio de 2000. Disponible en: http://www. secretariasenado.gov.co/senado/basedoc/ley_0600_2000.html

Colombia, Ley 906 de 2004, por la cual se expide el Código de Procedimiento Penal, 45.658 Diario Oficial, 1 de septiembre de 2004, corregida de conformidad con el Decreto 2770 de 2004. Disponible en: http://www.secretariasenado.gov.co/ senado/basedoc/ley_0906_2004.html

Colombia, Ley 1142 de 2007, por medio de la cual se reforman parcialmente las Leyes 906 de 2004, 599 de 2000 y 600 de 2000 y se adoptan medidas para la prevención y represión de la actividad delictiva de especial impacto para la convivencia y seguridad ciudadana, 46.673 Diario Oficial, 28 de julio de 2007. Disponible en: http://www.secretariasenado.gov.co/senado/basedoc/ley_1142_2007.html

\section{Jurisprudencia de la Corte Interamericana de Derechos Humanos, CorteIDH}

Corte Interamericana de Derechos Humanos, CorteIDH, Caso Caballero-Delgado y Santana vs. Colombia, Serie C 22, Sentencia de 8 de diciembre de 1995, fondo. Disponible en: http://www.corteidh.or.cr/docs/casos/articulos/seriec_22_esp.pdf

Corte Interamericana de Derechos Humanos, CorteIDH, Caso del Penal Miguel Castro-Castro vs. Perú, Serie C 160, Sentencia de 25 de noviembre de 2006, fondo, reparaciones y costas. Disponible en: http://www.corteidh.or.cr/docs/ casos/articulos/seriec_160_esp.pdf

Corte Interamericana de Derechos Humanos, CorteIDH, Caso Durand y Ugarte vs. Perú, Serie C 68, Sentencia de 16 de agosto de 2000, fondo. Disponible en: http:// 
www.corteidh.or.cr/docs/casos/articulos/Seriec_68_esp.pdf

Corte Interamericana de Derechos Humanos, CorteIDH, Caso Godinez-Cruz vs. Honduras, Serie C 05, Sentencia de 20 de enero de 1989, fondo. Disponible en: http://www.corteidh.or.cr/docs/casos/articulos/seriec_05_esp.pdf

Corte Interamericana de Derechos Humanos, CorteIDH, Caso Instituto de Reeducación del Menor vs. Paraguay, Serie C 112, Sentencia de 2 de septiembre de 2004, excepciones preliminares, fondos, reparaciones y costas. Disponible en: http:// www.corteidh.or.cr/docs/casos/articulos/seriec_112_esp.pdf

Corte Interamericana de Derechos Humanos, CorteIDH, Caso López-Álvarez vs. Honduras, Serie C 141, Sentencia de 1 de febrero de 2006, fondo, reparaciones y cosas. Disponible en: http://www.corteidh.or.cr/docs/casos/articulos/seriec_141_ esp.pdf

Corte Interamericana de Derechos Humanos, CorteIDH, Caso Mendoza y otros vs. Argentina, Serie C 260, Sentencia de 14 de mayo 2013, excepciones preliminares, fondo y reparaciones. Disponible en: http://www.corteidh.or.cr/docs/casos/ articulos/seriec_260_esp.pdf

Corte Interamericana de Derechos Humanos, CorteIDH, Caso Neira-Alegría y otros vs. Perú, Serie C 20, Sentencia de 19 de enero de 1995, fondo. Disponible en: http:// www.corteidh.or.cr/docs/casos/articulos/seriec_20_esp.pdf

Corte Interamericana de Derechos Humanos, CorteIDH, Caso Pacheco Teruel y otros vs. Honduras, Serie C 241, Sentencia de 27 de abril de 2012, fondo, reparaciones y costas. Disponible en: http://corteidh.or.cr/docs/casos/articulos/seriec_241_esp. pdf

Corte Interamericana de Derechos Humanos, CorteIDH, Caso Tibi vs. Ecuador, Serie C 114, Sentencia de 7 de septiembre de 2004, excepciones preliminares, fondo, reparaciones y costas. Disponible en: http://www.corteidh.or.cr/docs/casos/ articulos/seriec_114_esp.pdf

Corte Interamericana de Derechos Humanos, CorteIDH, Caso Velásquez-Rodríguez vs. Honduras, Serie C 04, Sentencia de 29 de julio de 1988, fondo. Disponible en: http://www.corteidh.or.cr/docs/casos/articulos/seriec_04_esp.pdf

Corte Interamericana de Derechos Humanos, CorteIDH, Caso Vélez Loor vs. Panamá, Serie C 218, sentencia de 23 de noviembre de 2010, excepciones preliminares, fondo, reparaciones y costas. Disponible en: http://www.corteidh.or.cr/docs/ casos/articulos/seriec_218_esp2.pdf

\section{Jurisprudencia colombiana}

Colombia, Corte Constitucional, Sentencia C-620-01, 13 de junio de 2001, magistrado ponente Jaime Araújo-Rentería. Disponible en: http://www.corteconstitucional. gov.co/relatoria/2001/c-620-01.htm

Colombia, Corte Constitucional, Sentencia SU327-95, 27 de julio de 1995, magistrado ponente Carlos Gaviria-Díaz. Disponible en: http://www.corteconstitucional. gov.co/relatoria/1995/SU327-95.htm

Colombia, Corte Constitucional, Sentencia SU707-96, 9 de diciembre de 1996, 
magistrado ponente Hernando Herrera-Vergara. Disponible en: http://www. corteconstitucional.gov.co/relatoria/1996/su707-96.htm

Colombia, Corte Constitucional, Sentencia SU1722-00, 12 de diciembre de 2000, magistrado ponente Jairo Charry-Rivas. Disponible en: http://www. corteconstitucional.gov.co/relatoria/2000/su1722-00.htm

Colombia, Corte Constitucional, Sentencia SU1299-01, 6 de diciembre de 2001, magistrado ponente Manuel José Cepeda-Espinosa. Disponible en: http://www. corteconstitucional.gov.co/relatoria/2001/su1299-01.htm

Colombia, Corte Constitucional, Sentencia T-424-92, 24 de junio de 1992, magistrado ponente Fabio Morón-Díaz. Disponible en: http://www.corteconstitucional.gov. co/relatoria/1992/t-424-92.htm

Colombia, Corte Constitucional, Sentencia T-522-92, 19 de septiembre de 1992, magistrado ponente Alejandro Martínez-Caballero. Disponible en: http://www. corteconstitucional.gov.co/relatoria/1992/t-522-92.htm

Colombia, Corte Constitucional, Sentencia T-538-92, 23 de septiembre de 1992, magistrado ponente Simón Rodríguez-Rodríguez. Disponible en: http://www. corteconstitucional.gov.co/relatoria/1992/t-538-92.htm

Colombia, Corte Constitucional, Sentencia T-596-92, 10 de diciembre de 1992, magistrado ponente Ciro Angarita-Barón. Disponible en: http://www.corteconstitucional. gov.co/relatoria/1992/t-596-92.htm

Colombia, Corte Constitucional, Sentencia T-601-92, 11 de diciembre de 1992, magistrado ponente Eduardo Cifuentes-Muñoz. Disponible en: http://www. corteconstitucional.gov.co/relatoria/1992/t-601-92.htm

Colombia, Corte Constitucional, Sentencia T-009-93, 18 de enero de 1993, magistrado ponente Eduardo Cifuentes-Muñoz. Disponible en: http://www. corteconstitucional.gov.co/relatoria/1993/t-009-93.htm

Corte Constitucional, Sentencia T-121-93, 29 de marzo de 1993, magistrado ponente Vladimiro Naranjo-Mesa. Disponible en: http://www.corteconstitucional.gov. co/relatoria/1993/t-121-93.htm

Colombia, Corte Constitucional, Sentencia T-219-93, 9 de junio de 1993, magistrado ponente Antonio Barrera-Carbonell. Disponible en: http://www. corteconstitucional.gov.co/relatoria/1993/t-219-93.htm

Colombia, Corte Constitucional, Sentencia T-222-93, 15 de junio de 1993, magistrado ponente Jorge Arango-Mejía. Disponible en: http://www.corteconstitucional. gov.co/relatoria/1993/t-222-93.htm

Colombia, Corte Constitucional, Sentencia T-273-93, 14 de julio de 1993, magistrado ponente Carlos Gaviria-Díaz. Disponible en: http://www.corteconstitucional. gov.co/relatoria/1993/t-273-93.htm

Colombia, Corte Constitucional, Sentencia T-349-93, 27 de agosto de 1993, magistrado ponente José Gregorio Hernández Galindo. Disponible en: http://www. corteconstitucional.gov.co/relatoria/1993/t-349-93.htm

Colombia, Corte Constitucional, Sentencia T-388-93, 15 de septiembre de 1993, magistrado ponente Hernando Herrera-Vergara. Disponible en: http://www. 
corteconstitucional.gov.co/relatoria/1993/t-388-93.htm

Colombia, Corte Constitucional, Sentencia T-494-93, 28 de octubre de 1993, magistrado ponente Vladimiro Naranjo Mesa. Disponible en: http://www. corteconstitucional.gov.co/relatoria/1993/t-494-93.htm

Colombia, Corte Constitucional, Sentencia T-575-93, 28 de octubre de 1993, magistrado ponente Eduardo Cifuentes Muñoz. Disponible en: http://www. corteconstitucional.gov.co/relatoria/1993/t-575-93.htm

Colombia, Corte Constitucional, Sentencia T-066-94, 17 de febrero de 1994, magistrado ponente Hernando Herrera-Vergara. Disponible en: http://www. corteconstitucional.gov.co/relatoria/1994/t-066-94.htm

Colombia, Corte Constitucional, Sentencia T-193-94, 20 de abril de 1994, magistrado ponente Jorge Arango-Mejía. Disponible en: http://www.corteconstitucional. gov.co/relatoria/1994/t-193-94.htm

Colombia, Corte Constitucional, Sentencia T-235-94, 17 de mayo de 1994, magistrado ponente Antonio Barrera-Carbonell. Disponible en: http://www. corteconstitucional.gov.co/relatoria/1994/t-235-94.htm

Colombia, Corte Constitucional, Sentencia T-277-94, 15 de junio de 1994, magistrado ponente Carlos Gaviria-Díaz. Disponible en: http://www.corteconstitucional. gov.co/relatoria/1994/t-277-94.htm

Colombia, Corte Constitucional, Sentencia T-324-94, 14 de julio de 1994, magistrado ponente Eduardo Cifuentes-Muñoz. Disponible en: http://www. corteconstitucional.gov.co/relatoria/1994/t-324-94.htm

Colombia, Corte Constitucional, Sentencia T-420-94, 23 de septiembre de 1994, magistrado ponente Eduardo Cifuentes-Muñoz. Disponible en: http://www. corteconstitucional.gov.co/relatoria/1994/t-420-94.htm

Colombia, Corte Constitucional, Sentencia T-501-94, 4 de noviembre de 1994, magistrado ponente Vladimiro Naranjo-Mesa. Disponible en: http://www. corteconstitucional.gov.co/relatoria/1994/t-501-94.htm

Colombia, Corte Constitucional, Sentencia T-502-94, 4 de noviembre de 1994, magistrado ponente Antonio Barrera-Carbonell. Disponible en: http://www. corteconstitucional.gov.co/relatoria/1994/t-502-94.htm

Colombia, Corte Constitucional, Sentencia T-065-95, 21 de febrero de 1995, magistrado ponente Alejandro Martínez-Caballero. Disponible en: http://www. corteconstitucional.gov.co/relatoria/1995/t-065-95.htm

Colombia, Corte Constitucional, Sentencia T-118-95, 16 de marzo de 1995, magistrado ponente José Gregorio Hernández-Galindo. Disponible en: http://www. corteconstitucional.gov.co/relatoria/1995/t-118-95.htm

Colombia, Corte Constitucional, Sentencia T-121-95, 21 de marzo de 1995, magistrado ponente José Gregorio Hernández-Galindo. Disponible en: http://www. corteconstitucional.gov.co/relatoria/1995/t-121-95.htm

Colombia, Corte Constitucional, Sentencia T-324-95, 26 de julio de 1995, magistrado ponente Alejandro Martínez-Caballero. Disponible en: http://www. corteconstitucional.gov.co/relatoria/1995/t-324-95.htm 
Colombia, Corte Constitucional, Sentencia T-408-95, 12 de septiembre de 1995, magistrado ponente Eduardo Cifuentes-Muñoz. Disponible en: http://www. corteconstitucional.gov.co/relatoria/1995/t-408-95.htm

Colombia, Corte Constitucional, Sentencia T-473-95, 19 de octubre de 1995, magistrado ponente Fabio Morón-Díaz. Disponible en: http://www.corteconstitucional.gov. co/relatoria/1995/t-473-95.htm

Colombia, Corte Constitucional, Sentencia T-555-95, 28 de noviembre de 1995, magistrado ponente Carlos Gaviria-Díaz. Disponible en: http://www.corteconstitucional. gov.co/relatoria/1995/t-555-95.htm

Colombia, Corte Constitucional, Sentencia T-066-96, 22 de febrero de 1996, magistrado ponente Fabio Morón-Díaz. Disponible en: http://www.corteconstitucional.gov. co/relatoria/1996/t-066-96.htm

Colombia, Corte Constitucional, Sentencia T-129-96, 27 de marzo de 1996, magistrado ponente Vladimiro Naranjo-Mesa. Disponible en: http://www. corteconstitucional.gov.co/relatoria/1996/t-129-96.htm

Colombia, Corte Constitucional, Sentencia T-207-96, 9 de mayo de 1996, magistrado ponente Hernando Herrera-Vergara. Disponible en: http://www. corteconstitucional.gov.co/relatoria/1996/t-207-96.htm

Colombia, Corte Constitucional, Sentencia T-247-96, 3 de junio de 1996, magistrado ponente José Gregorio Hernández-Galindo. Disponible en: http://www. corteconstitucional.gov.co/relatoria/1996/t-247-96.htm

Colombia, Corte Constitucional, Sentencia T-303-96, 10 de julio de 1996, magistrado ponente Jorge Arango-Mejía. Disponible en: http://www.corteconstitucional. gov.co/relatoria/1996/t-303-96.htm

Colombia, Corte Constitucional, Sentencia T-415-96, 4 de septiembre de 1996, magistrado ponente Eduardo Cifuentes-Muñoz. Disponible en: http://www. corteconstitucional.gov.co/relatoria/1996/t-415-96.htm

Colombia, Corte Constitucional, Sentencia T-470-96, 24 de septiembre de 1996, magistrado ponente Eduardo Cifuentes-Muñoz. Disponible en: http://www. corteconstitucional.gov.co/relatoria/1996/t-470-96.htm

Colombia, Corte Constitucional, Sentencia T-588-96, 5 de noviembre de 1996, magistrado ponente Eduardo Cifuentes-Muñoz. Disponible en: http://www. corteconstitucional.gov.co/relatoria/1996/t-588-96.htm

Colombia, Corte Constitucional, Sentencia T-645-96, 26 de noviembre de 1996, magistrado ponente Alejandro Martínez-Caballero. Disponible en: http://www. corteconstitucional.gov.co/relatoria/1996/t-645-96.htm

Colombia, Corte Constitucional, Sentencia T-654-96, 27 de noviembre de 1996, magistrado ponente Carlos Gaviria-Díaz. Disponible en: http://www. corteconstitucional.gov.co/relatoria/1996/t-654-96.htm

Colombia, Corte Constitucional, Sentencia T-680-96, 4 de diciembre de 1996, magistrado ponente Carlos Gaviria-Díaz. Disponible en: http://corteconstitucional.gov.co/ relatoria/1996/t-680-96.htm

Colombia, Corte Constitucional, Sentencia T-705-96, 9 de diciembre de 1996, 
magistrado ponente Eduardo Cifuentes-Muñoz. Disponible en: http://www. corteconstitucional.gov.co/relatoria/1996/t-705-96.htm

Colombia, Corte Constitucional, Sentencia T-706-96, 9 de diciembre de 1996, magistrado ponente Eduardo Cifuentes-Muñoz. Disponible en: http://www. corteconstitucional.gov.co/relatoria/1996/t-706-96.htm

Colombia, Corte Constitucional, Sentencia T-714-96, 16 de diciembre de 1996, magistrado ponente Eduardo Cifuentes-Muñoz. Disponible en: http://www. corteconstitucional.gov.co/relatoria/1996/t-714-96.htm

Colombia, Corte Constitucional, Sentencia T-021-97, 24 de enero de 1997, magistrado ponente Vladimiro Naranjo-Mesa. Disponible en: http://www. corteconstitucional.gov.co/relatoria/1997/t-021-97.htm

Colombia, Corte Constitucional, Sentencia T-101-97, 4 de marzo de 1997, magistrado ponente Fabio Morón-Díaz. Disponible en: http://www.corteconstitucional.gov. co/relatoria/1997/t-101-97.htm

Colombia, Corte Constitucional, Sentencia T-190-97, 10 de abril de 1997, magistrado ponente Alejandro Martínez-Caballero. Disponible en: http://www. corteconstitucional.gov.co/relatoria/1997/t-190-97.htm

Corte Constitucional, Sentencia T-263-97, 28 de mayo de 1997, magistrado ponente Hernando Herrera-Vergara. Disponible en: http://www.corteconstitucional.gov. co/relatoria/1997/t-263-97.htm

Colombia, Corte Constitucional, Sentencia T-305-97, 20 de junio de 1997, magistrado ponente José Gregorio Hernández-Galindo. Disponible en: http://www. corteconstitucional.gov.co/relatoria/1997/t-305-97.htm

Colombia, Corte Constitucional, Sentencia T-317-97, 25 de junio de 1997, magistrado ponente Vladimiro Naranjo-Mesa. Disponible en: http://www. corteconstitucional.gov.co/relatoria/1997/t-317-97.htm

Colombia, Corte Constitucional, Sentencia T-342-97, 18 de julio de 1997, magistrado ponente Hernando Herrera-Vergara. Disponible en: http://www. corteconstitucional.gov.co/relatoria/1997/t-342-97.htm

Colombia, Corte Constitucional, Sentencia T-359-97, 5 de agosto de 1997, magistrado ponente Jorge Arango-Mejía. Disponible en: http://www.corteconstitucional. gov.co/relatoria/1997/t-359-97.htm

Colombia, Corte Constitucional, Sentencia T-361-97, 5 de agosto de 1997, magistrado ponente Carlos Gaviria-Díaz. Disponible en: http://www.corteconstitucional. gov.co/relatoria/1997/t-361-97.htm

Colombia, Corte Constitucional, Sentencia T-415-97, 28 de agosto de 1997, magistrado ponente Hernando Herrera-Vergara. Disponible en: http://www. corteconstitucional.gov.co/relatoria/1997/t-415-97.htm

Colombia, Corte Constitucional, Sentencia T-435-97, 8 de septiembre de 1997, magistrado ponente José Gregorio Hernández-Galindo. Disponible en: http:// www.corteconstitucional.gov.co/relatoria/1997/t-435-97.htm

Colombia, Corte Constitucional, Sentencia T-483-97, 29 de septiembre de 1997, magistrado ponente Vladimiro Naranjo-Mesa. Disponible en: http://www. 
corteconstitucional.gov.co/relatoria/1997/t-483-97.htm

Colombia, Corte Constitucional, Sentencia T-605-97, 21 de noviembre de 1997, magistrado ponente Vladimiro Naranjo-Mesa. Disponible en: http://www. corteconstitucional.gov.co/relatoria/1997/t-605-97.htm

Colombia, Corte Constitucional, Sentencia T-150-98, 27 de abril de 1998, magistrado ponente Alejandro Martínez-Caballero. Disponible en: http://www. corteconstitucional.gov.co/relatoria/1998/t-150-98.htm

Colombia, Corte Constitucional, Sentencia T-153-98, 28 de abril de 1998, magistrado ponente Eduardo Cifuentes-Muñoz. Disponible en: http://www. corteconstitucional.gov.co/relatoria/1998/t-153-98.htm

Colombia, Corte Constitucional, Sentencia T-279-98, 4 de junio de 1998, magistrado ponente Hernando Herrera-Vergara. Disponible en: http://www. corteconstitucional.gov.co/relatoria/1998/t-279-98.htm

Colombia, Corte Constitucional, Sentencia T-296-98, 16 de junio de 1998, magistrado ponente Alejandro Martínez-Caballero. Disponible en: http://www. corteconstitucional.gov.co/relatoria/1998/t-296-98.htm

Colombia, Corte Constitucional, Sentencia T-349-98, 10 de julio de 1998, magistrado ponente Hernando Herrera-Vergara. Disponible en: http://www. corteconstitucional.gov.co/relatoria/1998/t-349-98.htm

Colombia, Corte Constitucional, Sentencia T-389-98, 31 de julio de 1998, magistrado ponente Fabio Morón-Díaz. Disponible en: http://www.corteconstitucional.gov. co/relatoria/1998/t-389-98.htm

Colombia, Corte Constitucional, Sentencia T-487-98, 10 de septiembre de 1998, magistrado ponente Alfredo Beltrán-Sierra. Disponible en: http://www. corteconstitucional.gov.co/relatoria/1998/t-487-98.htm

Colombia, Corte Constitucional, Sentencia T-490-98, 11 de septiembre de 1998, magistrado ponente Vladimiro Naranjo-Mesa. Disponible en: http://www. corteconstitucional.gov.co/relatoria/1998/t-490-98.htm

Colombia, Corte Constitucional, Sentencia T-517-98, 21 de septiembre de 1998, magistrado ponente Alejandro Martínez-Caballero. Disponible en: http://www. corteconstitucional.gov.co/relatoria/1998/t-517-98.htm

Colombia, Corte Constitucional, Sentencia T-535-98, 30 de septiembre de 1998, magistrado ponente José Gregorio Hernández-Galindo. Disponible en: http:// www.corteconstitucional.gov.co/relatoria/1998/t-535-98.htm

Colombia, Corte Constitucional, Sentencia T-583-98, 19 de octubre de 1998, magistrado ponente José Gregorio Hernández-Galindo. Disponible en: http://www. corteconstitucional.gov.co/relatoria/1998/t-583-98.htm

Colombia, Corte Constitucional, Sentencia T-590-98, 20 de octubre de 1998, magistrado ponente Alejandro Martínez-Caballero. Disponible en: http://www. corteconstitucional.gov.co/relatoria/1998/t-590-98.htm

Colombia, Corte Constitucional, Sentencia T-606-98, 27 de octubre de 1998, magistrado ponente José Gregorio Hernández-Galindo. Disponible en: http://www. corteconstitucional.gov.co/relatoria/1998/t-606-98.htm 
Colombia, Corte Constitucional, Sentencia T-607-98, 27 de octubre de 1998, magistrado ponente José Gregorio Hernández-Galindo. Disponible en: http://www. corteconstitucional.gov.co/relatoria/1998/t-607-98.htm

Colombia, Corte Constitucional, Sentencia T-063-99, 8 de febrero de 1999, magistrado ponente Vladimiro Naranjo-Mesa. Disponible en: http://www. corteconstitucional.gov.co/relatoria/1999/t-063-99.htm

Colombia, Corte Constitucional, Sentencia T-208-99, 12 de abril de 1999, magistrado ponente Vladimiro Naranjo-Mesa. Disponible en: http://www. corteconstitucional.gov.co/relatoria/1999/t-208-99.htm

Colombia, Corte Constitucional, Sentencia T-258-99, 21 de abril de 1999, magistrado ponente Antonio Barrera-Carbonell. Disponible en: http://www. corteconstitucional.gov.co/relatoria/1999/t-258-99.htm

Colombia, Corte Constitucional, Sentencia T-265-99, 23 de abril de 1999, magistrado ponente Eduardo Cifuentes-Muñoz. Disponible en: http://www. corteconstitucional.gov.co/relatoria/1999/t-265-99.htm

Colombia, Corte Constitucional, Sentencia T-524-99, 22 de julio de 1999, magistrado ponente Alfredo Beltrán-Sierra. Disponible en: http://www.corteconstitucional. gov.co/relatoria/1999/t-524-99.htm

Colombia, Corte Constitucional, Sentencia T-530-99, 26 de julio de 1999, magistrado ponente Vladimiro Naranjo-Mesa. Disponible en: http://www. corteconstitucional.gov.co/relatoria/1999/t-530-99.htm

Colombia, Corte Constitucional, Sentencia T-946-99, 29 de noviembre de 1999, magistrado ponente Antonio Barrera-Carbonell. Disponible en: http://www. corteconstitucional.gov.co/relatoria/1999/t-946-99.htm

Colombia, Corte Constitucional, Sentencia T-144-00, 22 de febrero de 2000, magistrado ponente Antonio Barrera-Carbonell. Disponible en: http://www. corteconstitucional.gov.co/relatoria/2000/t-144-00.htm

Colombia, Corte Constitucional, Sentencia T-256-00, 6 de marzo de 2000, magistrado ponente José Gregorio Hernández-Galindo. Disponible en: http://www. corteconstitucional.gov.co/relatoria/2000/t-256-00.htm

Colombia, Corte Constitucional, Sentencia T-257-00, 6 de marzo de 2000, magistrado ponente José Gregorio Hernández-Galindo. Disponible en: http://www. corteconstitucional.gov.co/relatoria/2000/t-257-00.htm

Colombia, Corte Constitucional, Sentencia T-334-00, 23 de marzo de 2000, magistrado ponente Eduardo Cifuentes-Muñoz. Disponible en: http://www. corteconstitucional.gov.co/relatoria/2000/t-334-00.htm

Colombia, Corte Constitucional, Sentencia T-352-00, 27 de marzo de 2000, magistrado ponente José Gregorio Hernández-Galindo. Disponible en: http://www. corteconstitucional.gov.co/relatoria/2000/t-352-00.htm

Colombia, Corte Constitucional, Sentencia T-415-00, 11 de abril de 2000, magistrado ponente Carlos Gaviria-Díaz. Disponible en: http://www.corteconstitucional. gov.co/relatoria/2000/t-415-00.htm

Colombia, Corte Constitucional, Sentencia T-592-00, 18 de mayo de 2000, magistrado 
ponente Alfredo Beltrán-Sierra. Disponible en: http://www.corteconstitucional. gov.co/relatoria/2000/t-592-00.htm

Colombia, Corte Constitucional, Sentencia T-607-00, 25 de mayo de 2000, magistrado ponente Carlos Gaviria-Díaz. Disponible en: http://www.corteconstitucional. gov.co/relatoria/2000/t-607-00.htm

Colombia, Corte Constitucional, Sentencia T-611-00, 29 de mayo de 2000, magistrado ponente Fabio Morón-Díaz. Disponible en: http://www.corteconstitucional.gov. co/relatoria/2000/t-611-00.htm

Colombia, Corte Constitucional, Sentencia T-847-00, 6 de julio de 2000, magistrado ponente Carlos Gaviria-Díaz. Disponible en: http://www.corteconstitucional. gov.co/relatoria/2000/t-847-00.htm

Colombia, Corte Constitucional, Sentencia T-966-00, 31 de julio de 2000, magistrado ponente Eduardo Cifuentes-Muñoz. Disponible en: http://www. corteconstitucional.gov.co/relatoria/2000/t-966-00.htm

Colombia, Corte Constitucional, Sentencia T-979-00, 31 de julio de 2000, magistrado ponente Alejandro Martínez-Caballero. Disponible en: http://www. corteconstitucional.gov.co/relatoria/2000/t-979-00.htm

Colombia, Corte Constitucional, Sentencia T-1003-00, 3 de agosto de 2000, magistrado ponente Álvaro Tafur-Galvis. Disponible en: http://www.corteconstitucional. gov.co/relatoria/2000/t-1003-00.htm

Colombia, Corte Constitucional, Sentencia T-1275-00, 21 de septiembre de 2000, magistrado ponente Carlos Gaviria-Díaz. Disponible en: http://www. corteconstitucional.gov.co/relatoria/2000/t-1275-00.htm

Colombia, Corte Constitucional, Sentencia T-1399-00, 19 de octubre de 2000, magistrado ponente Alfredo Beltrán-Sierra. Disponible en: http://www.corteconstitucional. gov.co/relatoria/2000/t-1399-00.htm

Colombia, Corte Constitucional, Sentencia T-1499-00, 2 de noviembre de 2000, magistrada ponente Martha Victoria Sáchica-Méndez. Disponible en: http:// www.corteconstitucional.gov.co/relatoria/2000/t-1499-00.htm

Colombia, Corte Constitucional, Sentencia T-1518-00, 9 de noviembre de 2000, magistrado ponente José Gregorio Hernández-Galindo. Disponible en: http:// www.corteconstitucional.gov.co/relatoria/2000/t-1518-00.htm

Colombia, Corte Constitucional, Sentencia T-1574-00, 14 de noviembre de 2000, magistrado ponente Fabio Morón-Díaz. Disponible en: http://www. corteconstitucional.gov.co/relatoria/2000/t-1574-00.htm

Colombia, Corte Constitucional, Sentencia T-1606-00, 21 de noviembre de 2000, magistrado ponente Fabio Morón-Díaz. Disponible en: http://www. corteconstitucional.gov.co/relatoria/2000/t-1606-00.htm

Colombia, Corte Constitucional, Sentencia T-1670-00, 5 de diciembre de 2000, magistrado ponente Carlos Gaviria-Díaz. Disponible en: http://www.corteconstitucional. gov.co/relatoria/2000/t-1670-00.htm

Colombia, Corte Constitucional, Sentencia T-1705-00, 11 de diciembre de 2000, magistrado ponente Jairo Charry-Rivas. Disponible en: http://www. 
corteconstitucional.gov.co/relatoria/2000/t-1705-00.htm

Colombia, Corte Constitucional, Sentencia T-1739-00, 11 de diciembre de 2000, magistrada ponente Cristina Pardo. Disponible en: http://www.corteconstitucional.gov.co/ relatoria/2000/t-1739-00.htm

Colombia, Corte Constitucional, Sentencia T-233-01, 26 de febrero de 2001, magistrado ponente Eduardo Montealegre-Lynett. Disponible en: http://www. corteconstitucional.gov.co/relatoria/2001/t-233-01.htm

Colombia, Corte Constitucional, Sentencia T-358-01, 2 de abril de 2001, magistrado ponente Alfredo Beltrán-Sierra. Disponible en: http://www.corteconstitucional. gov.co/relatoria/2001/t-358-01.htm

Colombia, Corte Constitucional, Sentencia T-495-01, 11 de mayo de 2001, magistrado ponente Rodrigo Escobar-Gil. Disponible en: http://www.corteconstitucional. gov.co/relatoria/2001/t-495-01.htm

Colombia, Corte Constitucional, Sentencia T-521-01, 18 de mayo de 2001, magistrado ponente Manuel José Cepeda-Espinosa. Disponible en: http://www. corteconstitucional.gov.co/relatoria/2001/t-521-01.htm

Colombia, Corte Constitucional, Sentencia T-533-01, 21 de mayo de 2001, magistrado ponente Jaime Cordoba-Triviño. Disponible en: http://www.corteconstitucional. gov.co/relatoria/2001/t-533-01.htm

Colombia, Corte Constitucional, Sentencia T-702-01, 5 de julio de 2001, magistrado ponente Marco Gerardo Monroy-Cabra. Disponible en: http://www. corteconstitucional.gov.co/relatoria/2001/t-702-01.htm

Colombia, Corte Constitucional, Sentencia T-728-01, 26 de febrero de 2001, magistrado ponente Rodrigo Escobar-Gil. Disponible en: http://www.corteconstitucional. gov.co/relatoria/2001/t-728-01.htm

Colombia, Corte Constitucional, Sentencia T-759-01, 17 de julio de 2001, magistrado ponente Jaime Araújo-Rentería. Disponible en: http://www.corteconstitucional. gov.co/relatoria/2001/t-759-01.htm

Colombia, Corte Constitucional, Sentencia T-773-01, 24 de julio de 2001, magistrada ponente Clara Inés Vargas-Hernández. Disponible en: http://www. corteconstitucional.gov.co/relatoria/2001/t-773-01.htm

Colombia, Corte Constitucional, Sentencia T-842-01, 9 de agosto de 2001, magistrado ponente Álvaro Tafur-Galvis. Disponible en: http://www.corteconstitucional. gov.co/relatoria/2001/t-842-01.htm

Colombia, Corte Constitucional, Sentencia T-879-01, 16 de agosto de 2001, magistrada ponente Clara Inés Vargas-Hernandez. Disponible en: http://www. corteconstitucional.gov.co/relatoria/2001/t-879-01.htm

Colombia, Corte Constitucional, Sentencia T-880-01, 16 de agosto de 2001, magistrada ponente Clara Inés Vargas-Hernández. Disponible en: http://www. corteconstitucional.gov.co/relatoria/2001/t-880-01.htm

Colombia, Corte Constitucional, Sentencia T-904-01, 26 de febrero de 2001, magistrado ponente Jaime Córdoba-Triviño. Disponible en: http://www.corteconstitucional. gov.co/relatoria/2001/t-904-01.htm 
Colombia, Corte Constitucional, Sentencia T-941-01, 3 de septiembre de 2001, magistrado ponente Jaime Araújo-Rentería. Disponible en: http://www.corteconstitucional. gov.co/relatoria/2001/t-941-01.htm

Colombia, Corte Constitucional, Sentencia T-944-01, 4 de septiembre de 2001, magistrada ponente Clara Inés Vargas-Hernández. Disponible en: http://www. corteconstitucional.gov.co/relatoria/2001/t-944-01.htm

Colombia, Corte Constitucional, Sentencia T-1077-01, 11 de octubre de 2001, magistrado ponente Jaime Araújo-Rentería. Disponible en: http://www.corteconstitucional. gov.co/relatoria/2001/t-1077-01.htm

Colombia, Corte Constitucional, Sentencia T-1171-01, 2 de noviembre de 2001, magistrado ponente Rodrigo Escobar Gil. Disponible en: http://www.corteconstitucional. gov.co/relatoria/2001/t-1171-01.htm

Colombia, Corte Constitucional, Sentencia T-1180-01, 8 de noviembre de 2001, magistrado ponente Marco Gerardo Monroy-Cabra. Disponible en: http://www. corteconstitucional.gov.co/relatoria/2001/t-1180-01.htm

Colombia, Corte Constitucional, Sentencia T-1223-01, 22 de noviembre de 2001, magistrado ponente Álvaro Tafur-Galvis. Disponible en: http://www. corteconstitucional.gov.co/relatoria/2001/t-1223-01.htm

Colombia, Corte Constitucional, Sentencia T-1226-01, 22 de noviembre de 2001, magistrado ponente Alfredo Beltrán-Sierra. Disponible en: http://www. corteconstitucional.gov.co/relatoria/2001/t-1226-01.htm

Colombia, Corte Constitucional, Sentencia T-1235-01, 22 de noviembre de 2001, magistrado ponente Jaime Araújo-Rentería. Disponible en: http://www. corteconstitucional.gov.co/relatoria/2001/t-1235-01.htm

Colombia, Corte Constitucional, Sentencia T-1307-01, 6 de diciembre de 2001, magistrado ponente Marco Gerardo Monroy-Cabra. Disponible en: http://www. corteconstitucional.gov.co/relatoria/2001/t-1307-01.htm

Colombia, Corte Constitucional, Sentencia T-1308-01, 7 de diciembre de 2001, magistrada ponente Clara Inés Vargas-Hernández. Disponible en: http://www. corteconstitucional.gov.co/relatoria/2001/t-1308-01.htm

Colombia, Corte Constitucional, Sentencia T-1345-01, 11 de diciembre de 2001, magistrado ponente Jaime Córdoba-Triviño. Disponible en: http://www. corteconstitucional.gov.co/relatoria/2001/t-1345-01.htm

Colombia, Corte Constitucional, Sentencia T-020-02, 23 de enero de 2002, magistrado ponente Jaime Araújo-Rentería. Disponible en: http://www.corteconstitucional. gov.co/relatoria/2002/t-020-02.htm

Colombia, Corte Constitucional, Sentencia T-022-02, 24 de enero de 2002, magistrado ponente Álvaro Tafur-Galvis. Disponible en: http://www.corteconstitucional. gov.co/relatoria/2002/t-022-02.htm

Colombia, Corte Constitucional, Sentencia T-062-02, 6 de febrero de 2002, magistrada ponente Clara Inés Vargas-Hernández. Disponible en: http://www. corteconstitucional.gov.co/relatoria/2002/t-062-02.htm

Colombia, Corte Constitucional, Sentencia T-077-02, 8 de febrero de 2002, magistrado 
ponente Manuel José Cepeda-Espinosa. Disponible en: http://www. corteconstitucional.gov.co/relatoria/2002/t-077-02.htm

Colombia, Corte Constitucional, Sentencia T-133-02, 28 de febrero de 2002, magistrado ponente Álvaro Tafur-Galvis. Disponible en: http://www.corteconstitucional. gov.co/relatoria/2002/t-133-02.htm

Colombia, Corte Constitucional, Sentencia T-169-02, 8 de marzo de 2002, magistrado ponente Manuel José Cepeda-Espinosa. Disponible en: http://www. corteconstitucional.gov.co/relatoria/2002/t-169-02.htm

Colombia, Corte Constitucional, Sentencia T-239-02, 5 de abril de 2002, magistrado ponente Alfredo Beltrán-Sierra. Disponible en: http://www.corteconstitucional. gov.co/relatoria/2002/t-239-02.htm

Colombia, Corte Constitucional, Sentencia T-269-02, 18 de abril de 2002, magistrado ponente Marco Gerardo Monroy-Cabra. Disponible en: http://www. corteconstitucional.gov.co/relatoria/2002/t-269-02.htm

Colombia, Corte Constitucional, Sentencia T-349-02, 9 de mayo de 2002, magistrado ponente Jaime Araújo-Rentería. Disponible en: http://www.corteconstitucional. gov.co/relatoria/2002/t-349-02.htm

Colombia, Corte Constitucional, Sentencia T-362-02, 9 de mayo de 2002, magistrado ponente Eduardo Montealegre-Lynett. Disponible en: http://www. corteconstitucional.gov.co/relatoria/2002/t-362-02.htm

Colombia, Corte Constitucional, Sentencia T-399-02, 23 de mayo de 2002, magistrado ponente Álvaro Tafur-Galvis. Disponible en: http://www.corteconstitucional. gov.co/relatoria/2002/t-399-02.htm

Colombia, Corte Constitucional, Sentencia T-461-02, 13 de junio de 2002, magistrado ponente Álvaro Tafur-Galvis. Disponible en: http://www.corteconstitucional. gov.co/relatoria/2002/t-461-02.htm

Colombia, Corte Constitucional, Sentencia T-668-02, 15 de agosto de 2002, magistrado ponente Eduardo Montealegre-Lynett. Disponible en: http://www. corteconstitucional.gov.co/relatoria/2002/t-668-02.htm

Colombia, Corte Constitucional, Sentencia T-698-02, 29 de agosto de 2002, magistrado ponente Jaime Araújo-Rentería. Disponible en: http://www.corteconstitucional. gov.co/relatoria/2002/t-698-02.htm

Colombia, Corte Constitucional, Sentencia T-705-02, 29 de agosto de 2002, magistrado ponente Manuel José Cepeda-Espinosa. Disponible en: http://www. corteconstitucional.gov.co/relatoria/2002/t-705-02.htm

Colombia, Corte Constitucional, Sentencia T-722-02, 5 de septiembre de 2002, magistrado ponente Marco Gerardo Monroy-Cabra. Disponible en: http://www. corteconstitucional.gov.co/relatoria/2002/t-722-02.htm

Colombia, Corte Constitucional, Sentencia T-775-02, 19 de septiembre de 2002, magistrado ponente Marco Gerardo Monroy-Cabra. Disponible en: http://www. corteconstitucional.gov.co/relatoria/2002/t-775-02.htm

Colombia, Corte Constitucional, Sentencia T-785-02, 19 de septiembre de 2002, magistrada ponente Clara Inés Vargas-Hernández. Disponible en: http://www. 
corteconstitucional.gov.co/relatoria/2002/t-785-02.htm

Colombia, Corte Constitucional, Sentencia T-839-02, 10 de octubre de 2002, magistrado ponente Álvaro Tafur-Galvis. Disponible en: http://www.corteconstitucional. gov.co/relatoria/2002/t-839-02.htm

Colombia, Corte Constitucional, Sentencia T-881-02, 17 de octubre de 2002, magistrado ponente Eduardo Montealegre-Lynett. Disponible en: http://www. corteconstitucional.gov.co/relatoria/2002/t-881-02.htm

Colombia, Corte Constitucional, Sentencia T-894-02, 24 de octubre de 2002, magistrado ponente Álvaro Tafur-Galvis. Disponible en: http://www.corteconstitucional. gov.co/relatoria/2002/t-894-02.htm

Colombia, Corte Constitucional, Sentencia T-895-02, 24 de octubre de 2002, magistrado ponente Álvaro Tafur-Galvis. Disponible en: http://www.corteconstitucional. gov.co/relatoria/2002/t-895-02.htm

Colombia, Corte Constitucional, Sentencia T-958-02, 7 de noviembre de 2002, magistrado ponente Eduardo Montealegre-Lynett. Disponible en: http://www. corteconstitucional.gov.co/relatoria/2002/t-958-02.htm

Colombia, Corte Constitucional, Sentencia T-986-02, 14 de noviembre de 2002, magistrado ponente Alfredo Beltrán-Sierra. Disponible en: http://www. corteconstitucional.gov.co/relatoria/2002/t-986-02.htm

Colombia, Corte Constitucional, Sentencia T-1002-02, 15 de noviembre de 2002, magistrado ponente Manuel José Cepeda-Espinosa. Disponible en: http://www. corteconstitucional.gov.co/relatoria/2002/t-1002-02.htm

Colombia, Corte Constitucional, Sentencia T-1006-02, 15 de noviembre de 2002, magistrado ponente Rodrigo Escobar-Gil. Disponible en: http://www. corteconstitucional.gov.co/relatoria/2002/t-1006-02.htm

Colombia, Corte Constitucional, Sentencia T-1045-02, 28 de noviembre de 2002, magistrado ponente Jaime Araújo-Rentería. Disponible en: http://www. corteconstitucional.gov.co/relatoria/2002/t-1045-02.htm

Colombia, Corte Constitucional, Sentencia T-1108-02, 5 de diciembre de 2002, magistrado ponente Álvaro Tafur-Galvis. Disponible en: http://www.corteconstitucional.gov. co/relatoria/2002/t-1108-02.htm

Colombia, Corte Constitucional, Sentencia T-023-03, 23 de enero de 2003, magistrada ponente Clara Inés Vargas-Hernández. Disponible en: http://www. corteconstitucional.gov.co/relatoria/2003/t-023-03.htm

Colombia, Corte Constitucional, Sentencia T-054-03, 30 de enero de 2003, magistrado ponente Álvaro Tafur-Galvis. Disponible en: http://www.corteconstitucional. gov.co/relatoria/2003/t-054-03.htm

Colombia, Corte Constitucional, Sentencia T-085-03, 6 de febrero de 2003, magistrado ponente Manuel José Cepeda-Espinosa. Disponible en: http://www. corteconstitucional.gov.co/relatoria/2003/t-085-03.htm

Colombia, Corte Constitucional, Sentencia T-172-03, 27 de febrero de 2003, magistrado ponente Jaime Córdoba-Triviño. Disponible en: http://www.corteconstitucional. gov.co/relatoria/2003/t-172-03.htm 
Colombia, Corte Constitucional, Sentencia T-310-03, 10 de abril de 2003, magistrada ponente Clara Inés Vargas-Hernández. Disponible en: http://www. corteconstitucional.gov.co/relatoria/2003/t-310-03.htm

Colombia, Corte Constitucional, Sentencia T-471-03, 5 de junio de 2003, magistrado ponente Álvaro Tafur-Galvis. Disponible en: http://www.corteconstitucional. gov.co/relatoria/2003/t-471-03.htm

Colombia, Corte Constitucional, Sentencia T-490-03, 6 de junio de 2003, magistrada ponente Clara Inés Vargas-Hernández. Disponible en: http://www. corteconstitucional.gov.co/relatoria/2003/t-490-03.htm

Colombia, Corte Constitucional, Sentencia T-493-03, 11 de junio de 2003, magistrada ponente Marco Gerardo Monroy-Cabra. Disponible en: http://www. corteconstitucional.gov.co/relatoria/2003/t-493-03.htm

Colombia, Corte Constitucional, Sentencia T-499-03, 12 de junio de 2003, magistrado ponente Álvaro Tafur-Galvis. Disponible en: http://www.corteconstitucional. gov.co/relatoria/2003/t-499-03.htm

Colombia, Corte Constitucional, Sentencia T-545-03, 9 de julio de 2003, magistrado ponente Manuel José Cepeda-Espinosa. Disponible en: http://www. corteconstitucional.gov.co/relatoria/2003/t-545-03.htm

Colombia, Corte Constitucional, Sentencia T-638-03, 31 de julio de 2003, magistrado ponente Álvaro Tafur-Galvis. Disponible en: http://www.corteconstitucional. gov.co/relatoria/2003/t-638-03.htm

Colombia, Corte Constitucional, Sentencia T-687-03, 8 de agosto de 2003, magistrado ponente Eduardo Montealegre-Lynett. Disponible en: http://www. corteconstitucional.gov.co/relatoria/2003/t-687-03.htm

Colombia, Corte Constitucional, Sentencia T-703-03, 14 de agosto de 2003, magistrada ponente Clara Inés Vargas-Hernández. Disponible en: http://www. corteconstitucional.gov.co/relatoria/2003/t-703-03.htm

Colombia, Corte Constitucional, Sentencia T-718-03, 20 de agosto de 2003, magistrado ponente Manuel José Cepeda-Espinosa. Disponible en: http://www. corteconstitucional.gov.co/relatoria/2003/t-718-03.htm

Colombia, Corte Constitucional, Sentencia T-750-03, 28 de agosto de 2003, magistrado ponente Jaime Araújo-Rentería. Disponible en: http://www.corteconstitucional. gov.co/relatoria/2003/t-750-03.htm

Colombia, Corte Constitucional, Sentencia T-758-03, 28 de agosto de 2003, magistrado ponente Álvaro Tafur-Galvis. Disponible en: http://www.corteconstitucional. gov.co/relatoria/2003/t-758-03.htm

Colombia, Corte Constitucional, Sentencia T-1025-03, 30 de octubre de 2003, magistrado ponente Alfredo Beltrán-Sierra. Disponible en: http://www.corteconstitucional. gov.co/relatoria/2003/t-1025-03.htm

Colombia, Corte Constitucional, Sentencia T-1030-03, 30 de octubre de 2003, magistrada ponente Clara Inés Vargas-Hernández. Disponible en: http://corteconstitucional. gov.co/relatoria/2003/t-1030-03.htm

Colombia, Corte Constitucional, Sentencia T-1082-03, 13 de noviembre de 2003, 
magistrado ponente Manuel José Cepeda-Espinosa. Disponible en: http://www. corteconstitucional.gov.co/relatoria/2003/t-1082-03.htm

Colombia, Corte Constitucional, Sentencia T-1168-03, 4 de diciembre de 2003, magistrada ponente Clara Inés Vargas-Hernández. Disponible en: http://www. corteconstitucional.gov.co/relatoria/2003/t-1168-03.htm

Colombia, Corte Constitucional, Sentencia T-1174-03, 4 de diciembre de 2003, magistrado ponente Jaime Araújo-Rentería. Disponible en: http://www.corteconstitucional. gov.co/relatoria/2003/t-1174-03.htm

Colombia, Corte Constitucional, Sentencia T-1190-03, 4 de diciembre de 2003, magistrado ponente Eduardo Montealegre-Lynett. Disponible en: http://www. corteconstitucional.gov.co/relatoria/2003/t-1190-03.htm

Colombia, Corte Constitucional, Sentencia T-1204-03, 10 de diciembre de 2003, magistrado ponente Alfredo Beltrán-Sierra. Disponible en: http://www. corteconstitucional.gov.co/relatoria/2003/t-1204-03.htm

Colombia, Corte Constitucional, Sentencia T-1206-03, 11 de diciembre de 2003, magistrado ponente Manuel José Cepeda-Espinosa. Disponible en: http://www. corteconstitucional.gov.co/relatoria/2003/t-1206-03.htm

Colombia, Corte Constitucional, Sentencia T-003-04, 15 de enero de 2004, magistrado ponente Alfredo Beltrán-Sierra. Disponible en: http://www.corteconstitucional. gov.co/relatoria/2004/t-003-04.htm

Colombia, Corte Constitucional, Sentencia T-388-04, 29 de abril de 2004, magistrado ponente Jaime Araújo-Rentería. Disponible en: http://www.corteconstitucional. gov.co/relatoria/2004/t-388-04.htm

Colombia, Corte Constitucional, Sentencia T-455-04, 11 de mayo de 2004, magistrado ponente Jaime Araújo-Rentería. Disponible en: http://www.corteconstitucional. gov.co/relatoria/2004/t-455-04.htm

Colombia, Corte Constitucional, Sentencia T-471-04, 17 de mayo de 2004, magistrado ponente Rodrigo Escobar-Gil. Disponible en: http://www.corteconstitucional. gov.co/relatoria/2004/t-471-04.htm

Colombia, Corte Constitucional, Sentencia T-490-04, 20 de mayo de 2004, magistrado ponente Eduardo Montealegre-Lynett. Disponible en: http://www. corteconstitucional.gov.co/relatoria/2004/t-490-04.htm

Colombia, Corte Constitucional, Sentencia T-639-04, 1 de julio de 2004, magistrado ponente Rodrigo Escobar-Gil. Disponible en: http://www.corteconstitucional. gov.co/relatoria/2004/t-639-04.htm

Colombia, Corte Constitucional, Sentencia T-679-04, 15 de julio de 2004, magistrado ponente Jaime Córdoba-Triviño. Disponible en: http://www.corteconstitucional. gov.co/relatoria/2004/t-679-04.htm

Colombia, Corte Constitucional, Sentencia T-684-04, 22 de julio de 2004, magistrada ponente Clara Inés Vargas-Hernández. Disponible en: http://www. corteconstitucional.gov.co/relatoria/2004/t-684-04.htm

Colombia, Corte Constitucional, Sentencia T-690-04, 22 de julio de 2004, magistrado ponente Álvaro Tafur-Galvis. Disponible en: http://www.corteconstitucional. 
gov.co/relatoria/2004/t-690-04.htm

Colombia, Corte Constitucional, Sentencia T-860-04, 2 de septiembre de 2004, magistrada ponente Clara Inés Vargas-Hernández. Disponible en: http://www. corteconstitucional.gov.co/relatoria/2004/t-860-04.htm

Colombia, Corte Constitucional, Sentencia T-1045-04, 21 de octubre de 2004, magistrado ponente Humberto Antonio Sierra-Porto. Disponible en: http:// www.corteconstitucional.gov.co/relatoria/2004/t-1045-04.htm

Colombia, Corte Constitucional, Sentencia T-1060-04, 28 de octubre de 2004, magistrado ponente Manuel José Cepeda-Espinosa. Disponible en: http://www. corteconstitucional.gov.co/relatoria/2004/t-1060-04.htm

Colombia, Corte Constitucional, Sentencia T-1074-04, 28 de octubre de 2004, magistrada ponente Clara Inés Vargas-Hernández. Disponible en: http://www. corteconstitucional.gov.co/relatoria/2004/t-1074-04.htm

Colombia, Corte Constitucional, Sentencia T-1096-04, 4 de noviembre de 2004, magistrado ponente Manuel José Cepeda-Espinosa. Disponible en: http://www. corteconstitucional.gov.co/relatoria/2004/t-1096-04.htm

Colombia, Corte Constitucional, Sentencia T-1134-04, 11 de noviembre de 2004, magistrado ponente Alfredo Beltrán-Sierra. Disponible en: http://www. corteconstitucional.gov.co/relatoria/2004/t-1134-04.htm

Colombia, Corte Constitucional, Sentencia T-1239-04, 9 de diciembre de 2004, magistrado ponente Rodrigo Escobar-Gil. Disponible en: http://www.corteconstitucional. gov.co/relatoria/2004/t-1239-04.htm

Colombia, Corte Constitucional, Sentencia T-052-05, 28 de enero de 2005, magistrado ponente Jaime Córdoba-Triviño. Disponible en: http://www.corteconstitucional. gov.co/relatoria/2005/t-052-05.htm

Colombia, Corte Constitucional, Sentencia T-066-05, 28 de enero de 2005, magistrado ponente Rodrigo Escobar-Gil. Disponible en: http://www.corteconstitucional. gov.co/relatoria/2005/t-066-05.htm

Colombia, Corte Constitucional, Sentencia T-134-05, 17 de febrero de 2005, magistrado ponente Manuel José Cepeda-Espinosa. Disponible en: http://www. corteconstitucional.gov.co/relatoria/2005/t-134-05.htm

Colombia, Corte Constitucional, Sentencia T-254-05, 17 de marzo de 2005, magistrado ponente Jaime Araújo-Rentería. Disponible en: http://www.corteconstitucional. gov.co/relatoria/2005/t-254-05.htm

Colombia, Corte Constitucional, Sentencia T-274-05, 17 de marzo de 2005, magistrado ponente Humberto Antonio Sierra-Porto. Disponible en: http://www. corteconstitucional.gov.co/relatoria/2005/t-274-05.htm

Colombia, Corte Constitucional, Sentencia T-507-05, 19 de mayo de 2005, magistrado ponente Alfredo Beltrán-Sierra. Disponible en: http://www.corteconstitucional. gov.co/relatoria/2005/t-507-05.htm

Colombia, Corte Constitucional, Sentencia T-572-05, 27 de mayo de 2005, magistrado ponente Álvaro Tafur-Galvis. Disponible en: http://www.corteconstitucional. gov.co/relatoria/2005/t-572-05.htm 
Colombia, Corte Constitucional, Sentencia T-577-05, 27 de mayo de 2005, magistrado ponente Humberto Sierra-Porto. Disponible en: http://www.corteconstitucional. gov.co/relatoria/2005/t-577-05.htm

Colombia, Corte Constitucional, Sentencia T-578-05, 27 de mayo de 2005, magistrado ponente Humberto Sierra-Porto. Disponible en: http://www.corteconstitucional. gov.co/relatoria/2005/t-578-05.htm

Colombia, Corte Constitucional, Sentencia T-584-05, 2 de junio de 2005, magistrado ponente Alfredo Beltrán-Sierra. Disponible en: http://www.corteconstitucional. gov.co/relatoria/2005/t-584-05.htm

Colombia, Corte Constitucional, Sentencia T-622-05, 16 de junio de 2005, magistrado ponente Álvaro Tafur-Galvis. Disponible en: http://www.corteconstitucional. gov.co/relatoria/2005/t-622-05.htm

Colombia, Corte Constitucional, Sentencia T-624-05, 16 de junio de 2005, magistrado ponente Álvaro Tafur-Galvis. Disponible en: http://www.corteconstitucional. gov.co/relatoria/2005/t-624-05.htm

Colombia, Corte Constitucional, Sentencia T-684-05, 30 de junio de 2005, magistrado ponente Marco Gerardo Monroy-Cabra. Disponible en: http:// corteconstitucional.gov.co/relatoria/2005/t-684-05.htm

Colombia, Corte Constitucional, Sentencia T-743-05, 14 de julio de 2005, magistrado ponente Alfredo Beltrán-Sierra. Disponible en: http://www.corteconstitucional. gov.co/relatoria/2005/t-743-05.htm

Colombia, Corte Constitucional, Sentencia T-792-05, 28 de julio de 2005, magistrada ponente Clara Inés Vargas-Hernández. Disponible en: http://www. corteconstitucional.gov.co/relatoria/2005/t-792-05.htm

Colombia, Corte Constitucional, Sentencia T-848-05, 16 de agosto de 2005, magistrado ponente José Manuel Cepeda-Espinosa. Disponible en: http://www. corteconstitucional.gov.co/relatoria/2005/t-848-05.htm

Colombia, Corte Constitucional, Sentencia T-900-05, 1 de septiembre de 2005, magistrado ponente Alfredo Beltrán-Sierra. Disponible en: http://www. corteconstitucional.gov.co/relatoria/2005/t-900-05.htm

Colombia, Corte Constitucional, Sentencia T-972-05, 23 de septiembre de 2005, magistrado ponente Jaime Córdoba-Triviño. Disponible en: http://www. corteconstitucional.gov.co/relatoria/2005/t-972-05.htm

Colombia, Corte Constitucional, Sentencia T-1013-05, 5 de octubre de 2005, magistrado ponente Alfredo Beltrán-Sierra. Disponible en: http://www.corteconstitucional. gov.co/relatoria/2005/t-1013-05.htm

Colombia, Corte Constitucional, Sentencia T-1084-05, 27 de octubre de 2005, magistrado ponente Alfredo Beltrán-Sierra. Disponible en: http://corteconstitucional.gov. co/relatoria/2005/t-1084-05.htm

Colombia, Corte Constitucional, Sentencia T-1093-05, 26 de octubre de 2005, magistrada ponente Clara Inés Vargas-Hernández. Disponible en: http://www. corteconstitucional.gov.co/relatoria/2005/t-1093-05.htm

Colombia, Corte Constitucional, Sentencia T-1096-05, 26 de octubre de 2005, 
magistrada ponente Clara Inés Vargas-Hernández. Disponible en: http://www. corteconstitucional.gov.co/relatoria/2005/t-1096-05.htm

Colombia, Corte Constitucional, Sentencia T-1145-05, 10 de noviembre de 2005, magistrado ponente Rodrigo Escobar-Gil. Disponible en: http://www. corteconstitucional.gov.co/relatoria/2005/t-1145-05.htm

Colombia, Corte Constitucional, Sentencia T-1180-05, 18 de noviembre de 2005, magistrado ponente Jaime Córdoba-Triviño. Disponible en: http://www. corteconstitucional.gov.co/relatoria/2005/t-1180-05.htm

Colombia, Corte Constitucional, Sentencia T-1221-05, 25 de noviembre de 2005, magistrado ponente Jaime Córdoba-Triviño. Disponible en: http://www. corteconstitucional.gov.co/relatoria/2005/t-1221-05.htm

Colombia, Corte Constitucional, Sentencia T-1259-05, 5 de diciembre de 2005, magistrado ponente Álvaro Tafur-Galvis. Disponible en: http://www.corteconstitucional.gov. co/relatoria/2005/t-1259-05.htm

Colombia, Corte Constitucional, Sentencia T-1275-05, 6 de diciembre de 2005, magistrado ponente Humberto Antonio Sierra-Porto. Disponible en: http:// www.corteconstitucional.gov.co/relatoria/2005/t-1275-05.htm

Colombia, Corte Constitucional, Sentencia T-1303-05, 9 de diciembre de 2005, magistrado ponente Jaime Córdoba-Triviño. Disponible en: http://www. corteconstitucional.gov.co/relatoria/2005/t-1303-05.htm

Colombia, Corte Constitucional, Sentencia T-1322-05, 15 de diciembre de 2005, magistrado ponente Manuel José Cepeda-Espinosa. Disponible en: http://www. corteconstitucional.gov.co/relatoria/2005/t-1322-05.htm

Colombia, Corte Constitucional, Sentencia T-1326-05, 15 de diciembre de 2005, magistrado ponente Humberto Antonio Sierra-Porto. Disponible en: http:// www.corteconstitucional.gov.co/relatoria/2005/t-1326-05.htm

Colombia, Corte Constitucional, Sentencia T-133-06, 23 de febrero de 2006, magistrado ponente Humberto Antonio Sierra-Porto. Disponible en: http://www. corteconstitucional.gov.co/relatoria/2006/t-133-06.htm

Colombia, Corte Constitucional, Sentencia T-291-06, 6 de abril de 2006, magistrado ponente Jaime Araújo-Rentería. Disponible en: http://www.corteconstitucional. gov.co/relatoria/2006/t-291-06.htm

Colombia, Corte Constitucional, Sentencia T-317-06, 24 de abril de 2006, magistrada ponente Clara Inés Vargas-Hernández. Disponible en: http://www. corteconstitucional.gov.co/relatoria/2006/t-317-06.htm

Colombia, Corte Constitucional, Sentencia T-346-06, 4 de mayo de 2006, magistrada ponente Clara Inés Vargas-Hernández. Disponible en: http://www. corteconstitucional.gov.co/relatoria/2006/t-346-06.htm

Colombia, Corte Constitucional, Sentencia T-361-06, 11 de mayo de 2006, magistrado ponente Jaime Araújo-Rentería. Disponible en: http://www.corteconstitucional. gov.co/relatoria/2006/t-361-06.htm

Colombia, Corte Constitucional, Sentencia T-376-06, 18 de mayo de 2006, magistrado ponente Marco Gerardo Monroy-Cabra. Disponible en: http://www. 
corteconstitucional.gov.co/relatoria/2006/t-376-06.htm

Colombia, Corte Constitucional, Sentencia T-439-06, 1 de junio de 2006, magistrado ponente Marco Gerardo Monroy-Cabra. Disponible en: http://www. corteconstitucional.gov.co/relatoria/2006/t-439-06.htm

Colombia, Corte Constitucional, Sentencia T-482-06, 22 de junio de 2006, magistrado ponente Álvaro Tafur-Galvis. Disponible en: http://www.corteconstitucional. gov.co/relatoria/2006/t-482-06.htm

Colombia, Corte Constitucional, Sentencia T-599-06, 27 de julio de 2006, magistrado ponente Álvaro Tafur-Galvis. Disponible en: http://www.corteconstitucional. gov.co/relatoria/2006/t-599-06.htm

Colombia, Corte Constitucional, Sentencia T-644-06, 8 de agosto de 2006, magistrado ponente Rodrigo Escobar-Gil. Disponible en: http://www.corteconstitucional. gov.co/relatoria/2006/t-644-06.htm

Colombia, Corte Constitucional, Sentencia T-686-06, 17 de agosto de 2006, magistrado ponente Humberto Antonio Sierra-Porto. Disponible en: http://www. corteconstitucional.gov.co/relatoria/2006/t-686-06.htm

Colombia, Corte Constitucional, Sentencia T-695-06, 22 de agosto de 2006, magistrado ponente Jaime Araújo-Rentería. Disponible en: http://www.corteconstitucional. gov.co/relatoria/2006/t-695-06.htm

Colombia, Corte Constitucional, Sentencia T-711-06, 22 de agosto de 2006, magistrado ponente Rodrigo Escobar-Gil. Disponible en: http://www.corteconstitucional. gov.co/relatoria/2006/t-711-06.htm

Colombia, Corte Constitucional, Sentencia T-723-06, 24 de agosto de 2006, magistrado ponente Nilson Pinilla-Pinilla. Disponible en: http://www.corteconstitucional. gov.co/relatoria/2006/t-723-06.htm

Colombia, Corte Constitucional, Sentencia T-724-06, 24 de agosto de 2006, magistrado ponente Álvaro Tafur-Galvis. Disponible en: http://www.corteconstitucional. gov.co/relatoria/2006/t-724-06.htm

Colombia, Corte Constitucional, Sentencia T-774-06, 8 de septiembre de 2006, magistrado ponente Rodrigo Escobar-Gil. Disponible en: http://www.corteconstitucional. gov.co/relatoria/2006/t-774-06.htm

Colombia, Corte Constitucional, Sentencia T-795-06, 21 de septiembre de 2006, magistrada ponente Clara Inés Vargas-Hernández. Disponible en: http://www. corteconstitucional.gov.co/relatoria/2006/t-795-06.htm

Colombia, Corte Constitucional, Sentencia T-797-06, 19 de septiembre de 2006, magistrado ponente Jaime Córdoba-Triviño. Disponible en: http://www. corteconstitucional.gov.co/relatoria/2006/t-797-06.htm

Colombia, Corte Constitucional, Sentencia T-808-06, 28 de septiembre de 2006, magistrado ponente Manuel José Cepeda-Espinosa. Disponible en: http://www. corteconstitucional.gov.co/relatoria/2006/t-808-06.htm

Colombia, Corte Constitucional, Sentencia T-842-06, 12 de octubre de 2006, magistrada ponente Clara Inés Vargas-Hernández. Disponible en: http://www. corteconstitucional.gov.co/relatoria/2006/t-842-06.htm 
Colombia, Corte Constitucional, Sentencia T-865-06, 19 de octubre de 2006, magistrado ponente Jaime Araújo-Rentería. Disponible en: http://www.corteconstitucional. gov.co/relatoria/2006/t-865-06.htm

Colombia, Corte Constitucional, Sentencia T-893A-06, 2 de noviembre de 2006, magistrado ponente Álvaro Tafur-Galvis. Disponible en: http://www. corteconstitucional.gov.co/relatoria/2006/t-893a-06.htm

Colombia, Corte Constitucional, Sentencia T-896A-06, 2 de noviembre de 2006, magistrado ponente Marco Gerardo Monroy-Cabra. Disponible en: http://www. corteconstitucional.gov.co/relatoria/2006/t-896a-06.htm

Colombia, Corte Constitucional, Sentencia T-897A-06, 2 de noviembre de 2006, magistrado ponente Marco Gerardo Monroy-Cabra. Disponible en: http://www. corteconstitucional.gov.co/relatoria/2006/t-897a-06.htm

Colombia, Corte Constitucional, Sentencia T-957-06, 17 de noviembre de 2006, magistrado ponente Jaime Araújo-Rentería. Disponible en: http://www. corteconstitucional.gov.co/relatoria/2006/t-957-06.htm

Colombia, Corte Constitucional, Sentencia T-963-06, 23 de noviembre de 2006, magistrada ponente Clara Inés Vargas-Hernández. Disponible en: http://www. corteconstitucional.gov.co/relatoria/2006/t-963-06.htm

Colombia, Corte Constitucional, Sentencia T-966-06, 23 de noviembre de 2006, magistrada ponente Clara Inés Vargas-Hernández. Disponible en: http://www. corteconstitucional.gov.co/relatoria/2006/t-966-06.htm

Colombia, Corte Constitucional, Sentencia T-970-06, 23 de noviembre de 2006, magistrado ponente Álvaro Tafur-Galvis. Disponible en: http://www. corteconstitucional.gov.co/relatoria/2006/t-970-06.htm

Colombia, Corte Constitucional, Sentencia T-1055-06, 7 de diciembre de 2006, magistrado ponente Jaime Araújo-Rentería. Disponible en: http://www. corteconstitucional.gov.co/relatoria/2006/t-1055-06.htm

Colombia, Corte Constitucional, Sentencia T-1062-06, 7 de diciembre de 2006, magistrada ponente Clara Inés Vargas-Hernández. Disponible en: http://www. corteconstitucional.gov.co/relatoria/2006/t-1062-06.htm

Colombia, Corte Constitucional, Sentencia T-048-07, 1 de febrero de 2007, magistrada ponente Clara Inés Vargas-Hernández. Disponible en: http://www. corteconstitucional.gov.co/relatoria/2007/t-048-07.htm

Colombia, Corte Constitucional, Sentencia T-161-07, 8 de marzo de 2007, magistrado ponente Jaime Araújo-Rentería. Disponible en: http://www.corteconstitucional. gov.co/relatoria/2007/t-161-07.htm

Colombia, Corte Constitucional, Sentencia T-232-07, 29 de marzo de 2007, magistrado ponente Jaime Córdoba-Triviño. Disponible en: http://www.corteconstitucional. gov.co/relatoria/2007/t-232-07.htm

Colombia, Corte Constitucional, Sentencia T-322-07, 4 de mayo de 2007, magistrado ponente Manuel José Cepeda-Espinosa. Disponible en: http://www. corteconstitucional.gov.co/relatoria/2007/t-322-07.htm

Colombia, Corte Constitucional, Sentencia T-355-07, 10 de mayo de 2007, magistrado 
ponente Humberto Antonio Sierra-Porto. Disponible en: http://www. corteconstitucional.gov.co/relatoria/2007/t-355-07.htm

Colombia, Corte Constitucional, Sentencia T-356-07, 10 de mayo de 2007, magistrado ponente Humberto Antonio Sierra-Porto. Disponible en: http://www. corteconstitucional.gov.co/relatoria/2007/t-356-07.htm

Colombia, Corte Constitucional, Sentencia T-357-07, 10 de mayo de 2007, magistrado ponente Humberto Antonio Sierra-Porto. Disponible en: http://www. corteconstitucional.gov.co/relatoria/2007/t-357-07.htm

Colombia, Corte Constitucional, Sentencia T-434-07, 29 de mayo de 2007, magistrado ponente Humberto Antonio Sierra-Porto. Disponible en: http://www. corteconstitucional.gov.co/relatoria/2007/t-434-07.htm

Colombia, Corte Constitucional, Sentencia T-488-07, 25 de junio de 2007, magistrado ponente Humberto Antonio Sierra-Porto. Disponible en: http:// corteconstitucional.gov.co/relatoria/2007/t-488-07.htm

Colombia, Corte Constitucional, Sentencia T-537-07, 13 de julio de 2007, magistrado ponente Nilson Pinilla-Pinilla. Disponible en: http://www.corteconstitucional. gov.co/relatoria/2007/t-537-07.htm

Colombia, Corte Constitucional, Sentencia T-566-07, 27 de julio de 2007, magistrada ponente Clara Inés Vargas-Hernández. Disponible en: http://www. corteconstitucional.gov.co/relatoria/2007/t-566-07.htm

Colombia, Corte Constitucional, Sentencia T-627-07, 15 de agosto de 2007, magistrada ponente Clara Inés Vargas-Hernández. Disponible en: http://www. corteconstitucional.gov.co/relatoria/2007/t-627-07.htm

Colombia, Corte Constitucional, Sentencia T-674-07, 30 de agosto de 2007, magistrado ponente Humberto Antonio Sierra-Porto. Disponible en: http://www. corteconstitucional.gov.co/relatoria/2007/t-674-07.htm

Colombia, Corte Constitucional, Sentencia T-693-07, 6 de septiembre de 2007, magistrado ponente Manuel José Cepeda-Espinosa. Disponible en: http://www. corteconstitucional.gov.co/relatoria/2007/t-693-07.htm

Colombia, Corte Constitucional, Sentencia T-694-07, 6 de septiembre de 2007, magistrado ponente Manuel José Cepeda-Espinosa. Disponible en: http://www. corteconstitucional.gov.co/relatoria/2007/t-694-07.htm

Colombia, Corte Constitucional, Sentencia T-739-07, 20 de septiembre de 2007, magistrado ponente Jaime Córdoba-Triviño. Disponible en: http://www. corteconstitucional.gov.co/relatoria/2007/t-739-07.htm

Colombia, Corte Constitucional, Sentencia T-750-07, 21 de septiembre de 2007, magistrada ponente Clara Inés Vargas-Hernández. Disponible en: http://www. corteconstitucional.gov.co/relatoria/2007/t-750-07.htm

Colombia, Corte Constitucional, Sentencia T-894-07, 25 de octubre de 2007, magistrada ponente Clara Inés Vargas-Hernández. Disponible en: http://www. corteconstitucional.gov.co/relatoria/2007/t-894-07.htm

Colombia, Corte Constitucional, Sentencia T-020-08, 22 de enero de 2008, magistrado ponente Jaime Araújo-Rentería. Disponible en: http://www.corteconstitucional. 
gov.co/relatoria/2008/t-020-08.htm

Colombia, Corte Constitucional, Sentencia T-178-08, 21 de febrero de 2008, magistrado ponente Rodrigo Escobar-Gil. Disponible en: http://www.corteconstitucional. gov.co/relatoria/2008/t-178-08.htm

Colombia, Corte Constitucional, Sentencia T-274-08, 11 de marzo de 2008, magistrado ponente Jaime Araújo-Rentería. Disponible en: http://www.corteconstitucional. gov.co/relatoria/2008/t-274-08.htm

Colombia, Corte Constitucional, Sentencia T-393-08, 24 de abril de 2008, magistrada ponente Clara Inés Vargas-Hernández. Disponible en: http://www. corteconstitucional.gov.co/relatoria/2008/t-393-08.htm

Colombia, Corte Constitucional, Sentencia T-402-08, 25 de abril de 2008, magistrado ponente Mauricio González-Cuervo. Disponible en: http://www. corteconstitucional.gov.co/relatoria/2008/t-402-08.htm

Colombia, Corte Constitucional, Sentencia T-436-08, 8 de mayo de 2008, magistrado ponente Marco Gerardo Monroy-Cabra. Disponible en: http://www. corteconstitucional.gov.co/relatoria/2008/t-436-08.htm

Colombia, Corte Constitucional, Sentencia T-515-08, 22 de mayo de 2008, magistrada ponente Clara Inés Vargas-Hernández. Disponible en: http://www. corteconstitucional.gov.co/relatoria/2008/t-515-08.htm

Colombia, Corte Constitucional, Sentencia T-522-08, 22 de mayo de 2008, magistrado ponente Manuel José Cepeda-Espinosa. Disponible en: http://www. corteconstitucional.gov.co/relatoria/2008/t-522-08.htm

Colombia, Corte Constitucional, Sentencia T-571-08, 4 de junio de 2008, magistrado ponente Humberto Antonio Sierra-Porto. Disponible en: http://www. corteconstitucional.gov.co/relatoria/2008/t-571-08.htm

Colombia, Corte Constitucional, Sentencia T-615-08, 23 de junio de 2008, magistrado ponente Rodrigo Escobar-Gil. Disponible en: http://www.corteconstitucional. gov.co/relatoria/2008/t-615-08.htm

Colombia, Corte Constitucional, Sentencia T-635-08, 26 de junio de 2008, magistrado ponente Mauricio González-Cuervo. Disponible en: http://www. corteconstitucional.gov.co/relatoria/2008/t-635-08.htm

Colombia, Corte Constitucional, Sentencia T-793-08, 19 de agosto de 2008, magistrado ponente Humberto Antonio Sierra-Porto. Disponible en: http://www. corteconstitucional.gov.co/relatoria/2008/t-793-08.htm

Colombia, Corte Constitucional, Sentencia T-815-08, 21 de agosto de 2008, magistrada ponente Clara Inés Vargas-Hernández. Disponible en: http://www. corteconstitucional.gov.co/relatoria/2008/t-815-08.htm

Colombia, Corte Constitucional, Sentencia T-1024-08, 17 de octubre de 2008, magistrado ponente Marco Gerardo Monroy-Cabra. Disponible en: http://www. corteconstitucional.gov.co/relatoria/2008/t-1024-08.htm

Colombia, Corte Constitucional, Sentencia T-1031-08, 17 de octubre de 2008, magistrado ponente Mauricio González-Cuervo. Disponible en: http://www. corteconstitucional.gov.co/relatoria/2008/t-1031-08.htm 
Colombia, Corte Constitucional, Sentencia T-1272-08, 18 de diciembre de 2008, magistrado ponente Mauricio González-Cuervo. Disponible en: http://www. corteconstitucional.gov.co/relatoria/2008/t-1272-08.htm

Colombia, Corte Constitucional, Sentencia T-061-09, 5 de febrero de 2009, magistrado ponente Marco Gerardo Monroy-Cabra. Disponible en: http://www. corteconstitucional.gov.co/relatoria/2009/t-061-09.htm

Colombia, Corte Constitucional, Sentencia T-093-09, 17 de febrero de 2009, magistrado ponente Mauricio González-Cuervo. Disponible en: http://www. corteconstitucional.gov.co/relatoria/2009/t-093-09.htm

Colombia, Corte Constitucional, Sentencia T-126-09, 24 de febrero de 2009, magistrado ponente Humberto Antonio Sierra-Porto. Disponible en: http://www. corteconstitucional.gov.co/relatoria/2009/t-126-09.htm

Colombia, Corte Constitucional, Sentencia T-185-09, 19 de marzo de 2009, magistrado ponente Juan Carlos Henao-Pérez. Disponible en: http://www. corteconstitucional.gov.co/relatoria/2009/t-185-09.htm

Colombia, Corte Constitucional, Sentencia T-210-09, 26 de marzo de 2009, magistrado ponente Nilson Pinilla-Pinilla. Disponible en: http://www.corteconstitucional. gov.co/relatoria/2009/t-210-09.htm

Colombia, Corte Constitucional, Sentencia T-412-09, 23 de junio de 2009, magistrada ponente María Victoria Calle-Correa. Disponible en: http://www. corteconstitucional.gov.co/relatoria/2009/t-412-09.htm

Colombia, Corte Constitucional, Sentencia T-435-09, 2 de julio de 2009, magistrado ponente Jorge Ignacio Pretelt-Chaljub. Disponible en: http://www. corteconstitucional.gov.co/relatoria/2009/t-435-09.htm

Colombia, Corte Constitucional, Sentencia T-462-09, 13 de julio de 2009, magistrado ponente Mauricio González-Cuervo. Disponible en: http://www. corteconstitucional.gov.co/relatoria/2009/t-462-09.htm

Colombia, Corte Constitucional, Sentencia T-511-09, 30 de julio de 2009, magistrado ponente Jorge Ignacio Pretelt-Chaljub. Disponible en: http://www. corteconstitucional.gov.co/relatoria/2009/t-511-09.htm

Colombia, Corte Constitucional, Sentencia T-527-09, 5 de agosto de 2009, magistrado ponente Nilson Pinilla-Pinilla. Disponible en: http://www.corteconstitucional. gov.co/relatoria/2009/t-527-09.htm

Colombia, Corte Constitucional, Sentencia T-540-09, 6 de agosto de 2009, magistrado ponente Jorge Ignacio Pretelt-Chaljub. Disponible en: http://www. corteconstitucional.gov.co/relatoria/2009/t-540-09.htm

Colombia, Corte Constitucional, Sentencia T-705-09, 6 de octubre de 2009, magistrado ponente Nelson Pinilla-Pinilla. Disponible en: http://www.corteconstitucional. gov.co/relatoria/2009/t-705-09.htm

Colombia, Corte Constitucional, Sentencia T-744-09, 19 de octubre de 2009, magistrado ponente Gabriel Eduardo Mendoza-Martelo. Disponible en: http://www. corteconstitucional.gov.co/relatoria/2009/t-744-09.htm

Colombia, Corte Constitucional, Sentencia T-825-09, 19 de noviembre de 2009, 
magistrado ponente Luis Ernesto Vargas-Silva. Disponible en: http://www. corteconstitucional.gov.co/relatoria/2009/t-825-09.htm

Colombia, Corte Constitucional, Sentencia T-844-09, 24 de noviembre de 2009, magistrado ponente Jorge Ignacio Pretelt-Chaljub. Disponible en: http://www. corteconstitucional.gov.co/relatoria/2009/t-844-09.htm

Colombia, Corte Constitucional, Sentencia T-971-09, 18 de diciembre de 2009, magistrado ponente Mauricio González-Cuervo. Disponible en: http://www. corteconstitucional.gov.co/relatoria/2009/t-971-09.htm

Colombia, Corte Constitucional, Sentencia T-023-10, 26 de enero de 2010, magistrado ponente Humberto Antonio Sierra-Porto. Disponible en: http://www. corteconstitucional.gov.co/relatoria/2010/t-023-10.htm

Colombia, Corte Constitucional, Sentencia T-139-10, 24 de febrero de 2010, magistrado ponente Mauricio González-Cuervo. Disponible en: http://www. corteconstitucional.gov.co/relatoria/2010/t-139-10.htm

Colombia, Corte Constitucional, Sentencia T-190-10, 18 de marzo de 2010, magistrado ponente Jorge Iván Palacio-Palacio. Disponible en: http://www. corteconstitucional.gov.co/relatoria/2010/t-190-10.htm

Colombia, Corte Constitucional, Sentencia T-193-10, 23 de marzo de 2010, magistrado ponente Nilson Pinilla-Pinilla. Disponible en: http://www.corteconstitucional. gov.co/relatoria/2010/t-193-10.htm

Colombia, Corte Constitucional, Sentencia T-395-10, 24 de mayo de 2010, magistrado ponente Jorge Ignacio Pretelt-Chaljub. Disponible en: http://www. corteconstitucional.gov.co/relatoria/2010/t-395-10.htm

Colombia, Corte Constitucional, Sentencia T-429-10, 28 de mayo de 2010, magistrado ponente Juan Carlos Henao-Pérez. Disponible en: http://www. corteconstitucional.gov.co/relatoria/2010/t-429-10.htm

Colombia, Corte Constitucional, Sentencia T-479-10, 16 de junio de 2010, magistrado ponente Juan Carlos Henao-Pérez. Disponible en: http://www. corteconstitucional.gov.co/relatoria/2010/t-479-10.htm

Colombia, Corte Constitucional, Sentencia T-499-10, 17 de junio de 2010, magistrado ponente Gabriel Eduardo Mendoza-Martelo. Disponible en: http://www. corteconstitucional.gov.co/relatoria/2010/t-499-10.htm

Colombia, Corte Constitucional, Sentencia T-545-10, 30 de junio de 2010, magistrado ponente Mauricio González-Cuervo. Disponible en: http://www. corteconstitucional.gov.co/relatoria/2010/t-545-10.htm

Colombia, Corte Constitucional, Sentencia T-622-10, 9 de agosto de 2010, magistrado ponente Nilson Pinilla-Pinilla. Disponible en: http://www.corteconstitucional. gov.co/relatoria/2010/t-622-10.htm

Colombia, Corte Constitucional, Sentencia T-690-10, 2 de septiembre de 2010, magistrado ponente Humberto Antonio Sierra-Porto. Disponible en: http:// www.corteconstitucional.gov.co/relatoria/2010/t-690-10.htm

Colombia, Corte Constitucional, Sentencia T-739-10, 13 de septiembre de 2010, magistrado ponente Mauricio González-Cuervo. Disponible en: http://www. 
corteconstitucional.gov.co/relatoria/2010/t-739-10.htm

Colombia, Corte Constitucional, Sentencia T-804-10, 7 de octubre de 2010, magistrado ponente Juan Carlos Henao-Pérez. Disponible en: http://www. corteconstitucional.gov.co/relatoria/2010/t-804-10.htm

Colombia, Corte Constitucional, Sentencia T-825-10, 19 de octubre de 2010, magistrado ponente Luis Ernesto Vargas-Silva. Disponible en: http://www. corteconstitucional.gov.co/relatoria/2010/t-825-10.htm

Colombia, Corte Constitucional, Sentencia T-888-10, 10 de noviembre de 2010, magistrada ponente María Victoria Calle-Correa. Disponible en: http://www. corteconstitucional.gov.co/relatoria/2010/t-888-10.htm

Colombia, Corte Constitucional, Sentencia T-062-11, 4 de febrero de 2011, magistrado ponente Luis Ernesto Vargas-Silva. Disponible en: http://www. corteconstitucional.gov.co/relatoria/2011/t-062-11.htm

Colombia, Corte Constitucional, Sentencia T-138-11, 4 de marzo de 2011, magistrada ponente María Victoria Calle-Correa. Disponible en: http://www. corteconstitucional.gov.co/relatoria/2011/t-138-11.htm

Colombia, Corte Constitucional, Sentencia T-161-11, 10 de marzo de 2011, magistrado ponente Humberto Antonio Sierra-Porto. Disponible en: http://www. corteconstitucional.gov.co/relatoria/2011/t-161-11.htm

Colombia, Corte Constitucional, Sentencia T-265-11, 7 de abril de 2011, magistrado ponente Jorge Ignacio Pretelt-Chaljub. Disponible en: http://www.corteconstitucional. gov.co/relatoria/2011/t-265-11.htm

Colombia, Corte Constitucional, Sentencia T-286-11, 14 de abril de 2011, magistrado ponente Jorge Ignacio Pretelt-Chaljub. Disponible en: http://www. corteconstitucional.gov.co/relatoria/2011/t-286-11.htm

Colombia, Corte Constitucional, Sentencia T-311-11, 3 de mayo de 2011, magistrado ponente Juan Carlos Henao-Pérez. Disponible en: http://www.corteconstitucional. gov.co/relatoria/2011/t-311-11.htm

Colombia, Corte Constitucional, Sentencia T-314-11, 4 de mayo de 2011, magistrado ponente Jorge Iván Palacio-Palacio. Disponible en: http://www. corteconstitucional.gov.co/relatoria/2011/t-314-11.htm

Colombia, Corte Constitucional, Sentencia T-319-11, 4 de mayo de 2011, magistrado ponente Jorge Iván Palacio-Palacio. Disponible en: http://www. corteconstitucional.gov.co/relatoria/2011/t-319-11.htm

Colombia, Corte Constitucional, Sentencia T-324-11, 4 de mayo de 2011, magistrado ponente Jorge Iván Palacio-Palacio. Disponible en: http://www. corteconstitucional.gov.co/relatoria/2011/t-324-11.htm

Colombia, Corte Constitucional, Sentencia T-374-11, 11 de mayo de 2011, magistrado ponente Jorge Ignacio Pretelt-Chaljub. Disponible en: http://www. corteconstitucional.gov.co/relatoria/2011/t-374-11.htm

Colombia, Corte Constitucional, Sentencia T-423-11, 17 de mayo de 2011, magistrado ponente Juan Carlos Henao-Pérez. Disponible en: http://www. corteconstitucional.gov.co/relatoria/2011/t-423-11.htm 
Colombia, Corte Constitucional, Sentencia T-669-11, 8 de septiembre de 2011, magistrado ponente Humberto Antonio Sierra-Porto. Disponible en: http:// www.corteconstitucional.gov.co/relatoria/2011/t-669-11.htm

Colombia, Corte Constitucional, Sentencia T-830-11, 2 de noviembre de 2011, magistrado ponente Jorge Iván Palacio-Palacio. Disponible en: http://www. corteconstitucional.gov.co/relatoria/2011/t-830-11.htm

Colombia, Corte Constitucional, Sentencia T-895-11, 30 de noviembre de 2011, magistrado ponente Gabriel Eduardo Mendoza-Martelo. Disponible en: http:// www.corteconstitucional.gov.co/relatoria/2011/t-895-11.htm

Colombia, Corte Constitucional, Sentencia T-942-11, 15 de diciembre de 2011, magistrado ponente Humberto Antonio Sierra-Porto. Disponible en: http:// www.corteconstitucional.gov.co/relatoria/2011/t-942-11.htm

Colombia, Corte Constitucional, Sentencia T-948-11, 16 de diciembre de 2011, magistrado ponente Juan Carlos Henao-Pérez. Disponible en: http://www. corteconstitucional.gov.co/relatoria/2011/t-948-11.htm

Colombia, Corte Constitucional, Sentencia T-163-12, 5 de marzo de 2012, magistrado ponente Gabriel Eduardo Mendoza-Martelo. Disponible en: http://www. corteconstitucional.gov.co/relatoria/2012/t-163-12.htm

Colombia, Corte Constitucional, Sentencia T-175-12, 8 de marzo de 2012, magistrada ponente María Victoria Calle-Correa. Disponible en: http://www. corteconstitucional.gov.co/relatoria/2012/t-175-12.htm

Colombia, Corte Constitucional, Sentencia T-232-12, 20 de marzo de 2012, magistrado ponente Gabriel Eduardo Mendoza-Martelo. Disponible en: http://www. corteconstitucional.gov.co/relatoria/2012/t-232-12.htm

Colombia, Corte Constitucional, Sentencia T-309-12, 24 de abril de 2012, magistrado ponente Jorge Iván Palacio-Palacio. Disponible en: http://www. corteconstitucional.gov.co/relatoria/2012/t-309-12.htm

Colombia, Corte Constitucional, Sentencia T-328-12, 3 de mayo de 2012, magistrada ponente María Victoria Calle-Correa. Disponible en: http://www. corteconstitucional.gov.co/relatoria/2012/t-328-12.htm

Colombia, Corte Constitucional, Sentencia T-377-12, 18 de mayo de 2012, magistrada ponente María Victoria Calle-Correa. Disponible en: http://www. corteconstitucional.gov.co/relatoria/2012/t-377-12.htm

Colombia, Corte Constitucional, Sentencia T-466-12, 21 de junio de 2012, magistrado ponente Jorge Iván Palacio-Palacio. Disponible en: http://www. corteconstitucional.gov.co/relatoria/2012/t-466-12.htm

Colombia, Corte Constitucional, Sentencia T-474-12, 25 de junio de 2012, magistrada ponente María Victoria Calle-Correa. Disponible en: http://www. corteconstitucional.gov.co/relatoria/2012/t-474-12.htm

Colombia, Corte Constitucional, Sentencia T-483-12, 25 de junio de 2012, magistrado ponente Gabriel Eduardo Mendoza-Martelo. Disponible en: http://www. corteconstitucional.gov.co/relatoria/2012/t-483-12.htm

Colombia, Corte Constitucional, Sentencia T-669-12, 24 de agosto de 2012, magistrado 
ponente Gabriel Eduardo Mendoza-Martelo. Disponible en: http://www. corteconstitucional.gov.co/relatoria/2012/t-669-12.htm

Colombia, Corte Constitucional, Sentencia T-739-12, 25 de septiembre de 2012, magistrado ponente Nilson Pinilla-Pinilla. Disponible en: http://www. corteconstitucional.gov.co/relatoria/2012/t-739-12.htm

Colombia, Corte Constitucional, Sentencia T-761-12, 2 de octubre de 2012, magistrado ponente Gabriel Eduardo Mendoza-Martelo. Disponible en: http://www. corteconstitucional.gov.co/relatoria/2012/t-761-12.htm

Colombia, Corte Constitucional, Sentencia T-764-12, 2 de octubre de 2012, magistrado ponente Jorge Ignacio Pretelt-Chaljub. Disponible en: http://www. corteconstitucional.gov.co/relatoria/2012/t-764-12.htm

Colombia, Corte Constitucional, Sentencia T-792A-12, 11 de octubre de 2012, magistrado ponente Alexei Egor Julio-Estrada. Disponible en: http://www. corteconstitucional.gov.co/relatoria/2012/t-792a-12.htm

Colombia, Corte Constitucional, Sentencia T-865-12, 25 de octubre de 2012, magistrado ponente Alexei Egor Julio-Estrada. Disponible en: http://www. corteconstitucional.gov.co/relatoria/2012/t-865-12.htm

Colombia, Corte Constitucional, Sentencia T-954-12, 20 de noviembre de 2012, magistrado ponente Mauricio González-Cuervo. Disponible en: http://www. corteconstitucional.gov.co/relatoria/2012/t-954-12.htm

Colombia, Corte Constitucional, Sentencia T-959-12, 20 de noviembre de 2012, magistrado ponente Mauricio González-Cuervo. Disponible en: http://www. corteconstitucional.gov.co/relatoria/2012/t-959-12.htm

Colombia, Corte Constitucional, Sentencia T-388-13, 28 de junio de 2013, magistrada ponente María Victoria Calle-Correa. Disponible en: http://www. corteconstitucional.gov.co/relatoria/2013/t-388-13.htm

Colombia, Corte Constitucional, Sentencia T-771-13, 7 de noviembre de 2013, magistrada ponente María Victoria Calle-Correa. Disponible en: http://www. corteconstitucional.gov.co/relatoria/2013/t-771-13.htm

Colombia, Corte Constitucional, Sentencia T-063-15, 13 de febrero de 2015, magistrada ponente María Victoria Calle-Correa. Disponible en: http://www. corteconstitucional.gov.co/relatoria/2015/t-063-15.htm

Colombia, Corte Constitucional, Sentencia T-208-15, 20 de abril de 2015, magistrada ponente Gloria Stella Ortiz-Delgado. Disponible en: http://www. corteconstitucional.gov.co/relatoria/2015/t-208-15.htm

Colombia, Corte Suprema de Justicia, radicado 17108, 2005, magistrado ponente Jorge Luis Quintero-Milanés.

Colombia, Corte Suprema de Justicia, radicado 24196, 2005, magistrada ponente Marina Pulido de Barón.

Colombia, Corte Suprema de Justicia, radicado 25705, 2006, magistrado ponente Alfredo Gómez-Quintero.

Colombia, Corte Suprema de Justicia, radicado 27153, 2007, magistrado ponente Sigifredo Espinosa-Pérez. 
Colombia, Corte Suprema de Justicia, radicado 27128, 2007, magistrado ponente Mauro Solarte-Portilla.

Colombia, Corte Suprema de Justicia, radicado 26945, 2007, magistrados ponentes Yesid Ramírez-Bastidas y Julio Socha-Salamanca.

\section{Medios de comunicación}

El Tiempo, Cárceles y presos de Colombia. El país detrás de las rejas. La precaria situación de las cárceles, El Tiempo (octubre de 2014). Disponible en: http://www.eltiempo. com/multimedia/infografias/carceles-y-presos-de-colombia/14739475

Escorcia, Daniel, Van 17 internos muertos por incendio en cárcel de Barranquilla, El Tiempo (5 de febrero de 2014). Disponible en: http://www.eltiempo.com/archivo/ documento/CMS-13454358

Redacción política, Aprobada ley Rosa Elvira Cely que castiga hasta con 50 años los feminicidios, El Espectador (2 de junio de 2015). Disponible en: http://www. elespectador.com/noticias/politica/aprobada-ley-rosa-elvira-cely-castiga-hasta50-anos-los-articulo-564105

\section{Informes oficiales}

Instituto Nacional Penitenciario y Carcelario, INPEC, Estadísticas a enero de 2016 (Instituto Nacional Penitenciario y Carcelario, INPEC, Bogotá, 2016). Disponible en: http://www.inpec.gov.co/portal/page/portal/INPEC_ CONTENIDO/NOTICIAS $\% 20 \mathrm{Y} \% 20$ NORMATIVIDAD/ESTADISTICAS/ Tab/ESTADISTICA\%20A\%20ENERO \%20DE\%202016\%20(Publicaci\%F3n).xls

Instituto Nacional Penitenciario y Carcelario, INPEC, Series históricas enero de 2016 (Instituto Nacional Penitenciario y Carcelario, INPEC, Bogotá, 2016). Disponible en: http://www.inpec.gov.co/portal/page/portal/INPEC_CONTENIDO/ NOTICIAS $\% 20 \mathrm{Y} \% 20$ NORMATIVIDAD/ESTADISTICAS/Tab/SERIES $\% 20$ HIST\%D3RICAS\%20ENERO\%20DE\%202016.xlsx 